Florida International University FIU Digital Commons

\title{
The origin, phylogenetics and natural history of darwiniothamnus (Asteraceae: Astereae), an endemic shrub of the Galapagos Islands
}

Nicole Genet Andrus

Florida International University

DOI: $10.25148 /$ etd.FI14032319

Follow this and additional works at: https://digitalcommons.fiu.edu/etd

Part of the Biology Commons

\section{Recommended Citation}

Andrus, Nicole Genet, "The origin, phylogenetics and natural history of darwiniothamnus (Asteraceae: Astereae), an endemic shrub of the Galapagos Islands" (2002). FIU Electronic Theses and Dissertations. 1290.

https://digitalcommons.fiu.edu/etd/1290 


\section{FLORIDA INTERNATIONAL UNIVERSITY}

Miami, Florida

THE ORIGIN, PHYLOGENETICS AND NATURAL HISTORY OF

DARWINIOTHAMNUS (ASTERACEAE: ASTEREAE), AN ENDEMIC SHRUB OF THE GALAPAGOS ISLANDS

A thesis submitted in partial fulfillment of the

requirements for the degree of

MASTER OF SCIENCE

in

BIOLOGY

by

Nicole Genet Andrus

2002 
To: Dean Arthur W. Herriott

College of Arts and Sciences

This thesis, written by Nicole Genet Andrus, and entitled The Origin, Phylogenetics and Natural History of Darwiniothamnus (Asteraceae: Astereae), an Endemic Shrub of the Galapagos Islands, having been approved in respect to style and intellectual content, is referred to you for judgment.

We have read this thesis and recommend that it be approved.

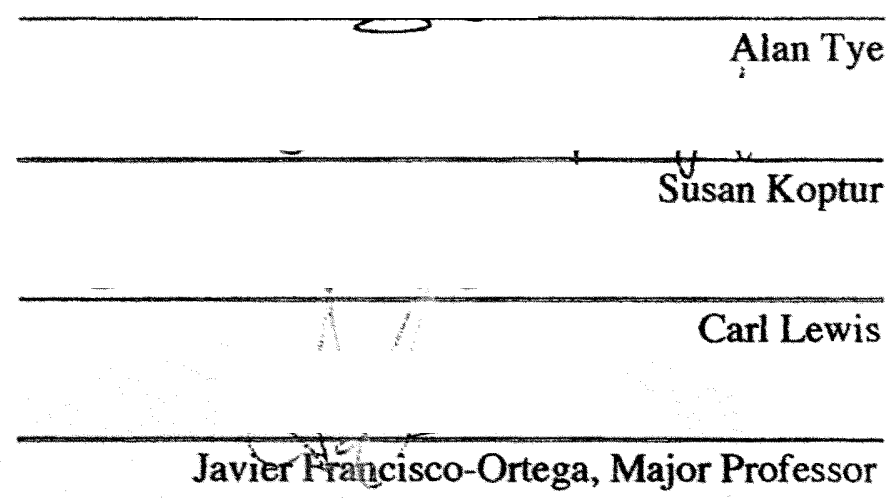

Date of Defense: July 24, 2002

The thesis of Nicole Genet Andrus is approved.

Dean Arthur W. Herriott College of Arts and Sciences

$7 \%$ Dean Douglas Wartzok University Graduate School

Florida International University, 2002 


\section{DEDICATION}

I dedicate this thesis to my parents, without their patience, understanding and support, the completion of this work would not have been possible; and to my

grandmothers Irene Furman and Gail Andrus, who's love and strength has given me more inspiration than they know.

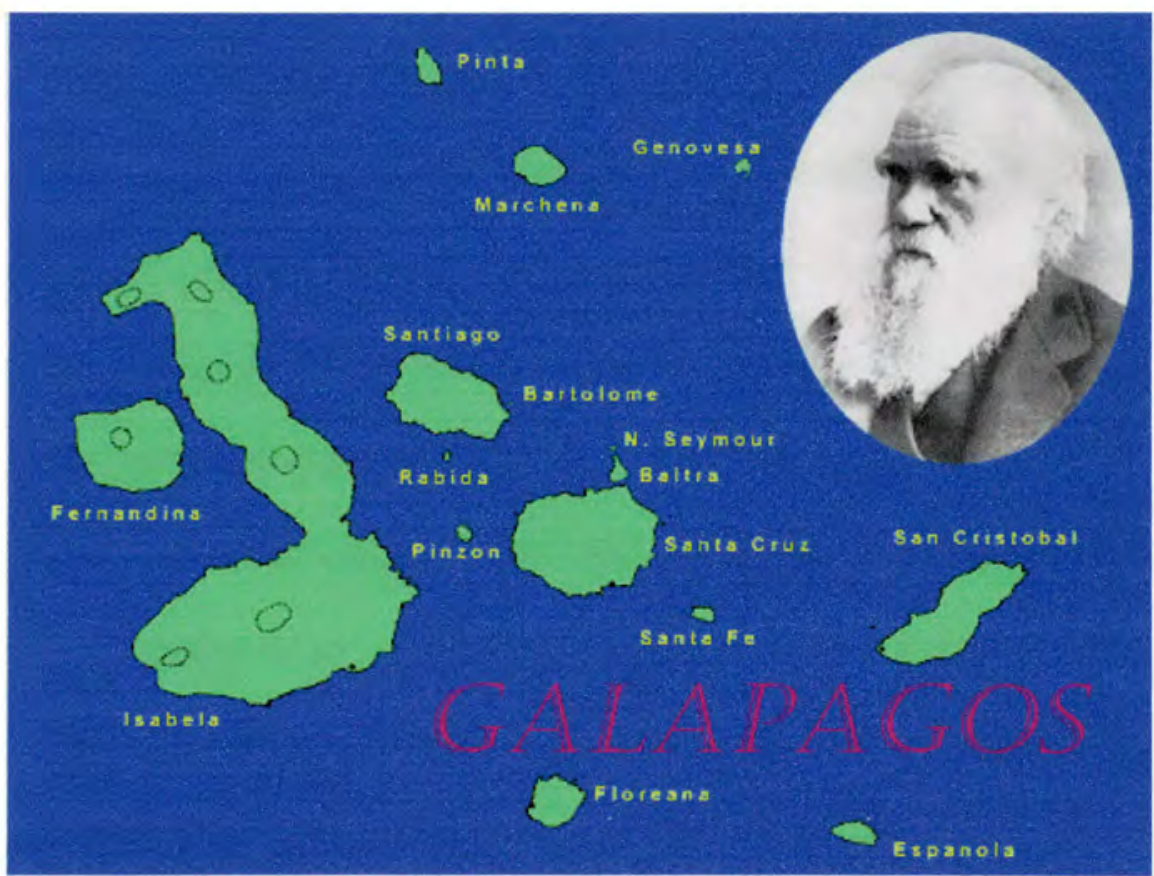




\section{ACKNOWLEDGMENTS}

I wish to thank the members of my committee for their support, patience and excellent advice. Dr. Alan Tye was instrumental in helping me to coordinate this Master's project and without his commanding knowledge of the flora and fauna from the Galapagos Islands, I most certainly would have gotten lost both in the field and when writing. Dr. Carl E. Lewis was particularly helpful in assisting me with all aspects of applied phylogenetics and phylogenetic theory. Dr. Susan Koptur's support and complete understanding of all of FIU's policies and procedures thankfully assured my successful completion of the Masters program. Finally, I would like to thank my major professor, Dr. Javier Francisco-Ortega. From the beginning, he had confidence in my abilities to not only complete my degree, but to complete it with excellence. His immense knowledge of and enthusiasm for the fields of island biogeography and plant systematics made it a privilege to learn under his tutelage.

I would also like to give special thanks to all employees of the Charles Darwin Research Station and the Galapagos National Park Service for their beneficent support during my stay the Galapagos Islands. The head of the park service on Isla Isabela, Juan Chavez, generously allowed me to join the park guards on one of their field excursions to Cerro Azul, which allowed me to collect at a site that otherwise would have been impossible. I thank them for showing a genuine interest in doing their best to safeguard the future of Darwiniothamnus with in the archipelago. In addition, the logistics of my trip would not have gone off so smoothly if it were not for the help of Poly Robayo and Edwin Yanez of the CDRS who were always ready to help me with anything and with a smile. 
In addition, initial advice on lab techniques and phylogenetic theory was provided by Dr. David Bogler during his time as a postdoc at the Fairchild Tropical Garden Research Center. Dr. Guy Nesom of the Botanical Research Institute of Texas provided invaluable help in the identification of several unknown taxa and shared his immense knowledge on the interrelationships of members from the tribe Astereae. Additional instruction on phylogenetic theory, practice, and training in automated sequencing was generously provided by Dr. Tim Collins and various members of his molecular lab at Florida International University.

Leaf material for this project was provided by several different herbaria and botanists from around the Caribbean, South America, the United States and Mexico. People deserving special thanks include: Dr. Ximena Agiure (QCNE) of Ecuador, Dr. Jorge Crisci (LPS) of Argentina, Jose Garcia-Franco (LL) of Mexico, Dr. Gerald Guala (FTG) of Miami, Dr. Francisco Jimenez (JBSD) of the Dominican Republic, Dr. Clodomiro Marticorena (CONC) of Chile, Dr. Ramona (HAC) of Cuba, Dr. Jose Panero (University of Texas), Dr. Eugenio Santiago of Puerto Rico, and Walter Simbaña and Novarino Castillo (CDS) of the Galápagos.

Financial support was for this project was made possible by generous grants from the Botanical Society of America, the American Society of Plant Taxonomists, Dr. Javier Francisco-Ortega's Start-up funds, and the Tropical Biology program of Florida International University. Desk space, lab space and laboratory supplies were also kindly provided by the Fairchild Tropical Garden research center. 
ABSTRACT OF THE THESIS

THE ORIGIN, PHYLOGENETICS AND NATURAL HISTORY OF

DARWINIOTHAMNUS (ASTERACEAE: ASTEREAE), AN ENDEMIC SHRUB OF

THE GALAPAGOS ISLANDS

by

Nicole Genet Andrus

Florida International University, 2002

Miami, Florida

Professor Javier Francisco-Ortega, Major Professor

Darwiniothamnus (Asteraceae:Astereae), one of seven plant genera endemic to the Galápagos Islands, has until recently had an unknown origin, number of species, and conservation status. The purpose of this master's thesis was to determine the origin and phylogenetics of Darwiniothamnus and to outline the major ecological factors influencing the survival of this genus.

Material for this thesis was sequenced from the ITS (Internal Transcribed Spacer) region of 18-26S nuclear ribosomal DNA of putative sister taxa from South, Central and North America, Mexico and the Caribbean. A molecular phylogeny was then constructed using fifty-four representatives from the tribe Astereae. Sequence data suggested that Darwiniothamnus is polyphyletic, nested within the paraphyletic Erigeron-Conyza complex, and stems from two separate introductions into the Galápagos. Additional information regarding the current biological threats on extant populations of 
Darwiniothamnus, nomenclatural suggestions for potential new taxa, and hypotheses on the disjunct distribution of Darwiniothamnus throughout the archipelago are also provided within the thesis. 


\section{TABLE OF CONTENTS}

CHAPTER

PAGE

I. INTRODUCTION INTO THE THESIS AND THE GENUS DARWINIOTHAMNUS

1. General Introduction................................................ 1

2. History of Research on Darwiniothamnus ...........................4

i. History of taxonomical and morphological treatments...........4

ii. Purpose of Study .......................................... 10

iii. $\quad$ Research Questions....................................... 12

II. NATURAL HISTORY OF THE GALAPAGOS ISLANDS

1. Geology/age of the Galapagos Islands.............................. 17

2. Climate and vegetation types ..................................... 19

3. Summary of botanical collections from Darwin to present............. 20

4. Review of plant endemicity in the archipelago: rarity, radiation, and sources of origin........................................... 24

5. Review of the Asteraceae within the archipelago: origin, history and modes of dispersal.............................................26

i. Introduction into the Asteraceae.............................26

ii. The Asteraceae of the Galápagos...........................27

III. FIELD OBSERVATIONS AND ECOLOGICAL NOTES

1. Distribution and habitat of Darwiniothamnus ....................... 45

2. Biological threats on extant populations of Darwiniothamnus..........47

3. Soil observations and analyses.....................................5 50

i. Introduction............................................ 50

ii. Soil collection methodology ...............................50

iii. Results.................................................. 51

iv. Discussion.................................................56

IV. ORIGIN AND PHYLOGENETICS OF DARWINIOTHAMNUS

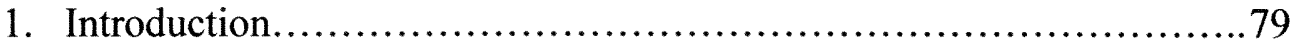

2. A brief description of the Astereae .............................. 81

3. Relevant historical research on the genus Erigeron ................... 83

4. The value of using ITS sequences in phylogentic studies................85

5. An introduction into the Phylogenetics of Darwiniothamnus...........87 87

i. $\quad$ Objectives of this study ............................... 87

ii. Materials and Methods................................... 88

a. Sampling Scheme.................................88

b. Outgroup selection............................... 89

c. Phylogenetic Analyses............................ 92

iii. Results.............................................. 94 
iv. Discussion

a. A Caribbean origin.

.98

b. A South American origin. 100

CONCLUDING REMARKS ON ALL THE CHAPTERS. 102

NOMENCLATURAL CONCLUSIONS.................................... 106

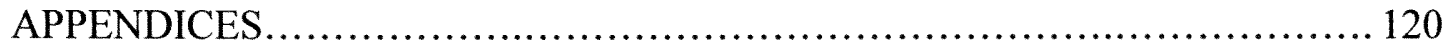




\section{LIST OF TABLES}

TABLE

1.1: Synopsis of recent taxonomic classification by various authors....

4.2: Description of the species of Darwiniothamnus........................... 14

2.1: History of collections in the Galápagos Islands from $1825-1930 \ldots \ldots \ldots \ldots \ldots . . . .34$

2.2: Radiative groups in the Galápagos of at least 3 endemic taxa.................. 34

2.3: Taxa in vulnerable status (VU) according to the 2000 criteria of the IUCN.....35

2.4: Taxa in danger of extinction (EN) according to the 2000 criteria of the IUCN..37

2.5: Taxa in critical danger of extinction (CR) according to the 2000 criteria of the IUCN..................................................................... 37

3.1: Invasive species in Galapagos, known or suspected to be causing significant ecological change ............................................................... 58

3.2: Naturalized species, which are still relatively uncommon but are known to be damaging aggressives in other parts of the world or suspected of capacity to be so in Galapagos.

3.3: List of Soil Analyses run and methods used at the Growers Testing Service, Visalia, California...

3.4: Description of Soil collection sites 63

3.5: Results of soil analyses for each collection site within the Galápagos Islands.. 66

3.6: Significant results of soil analyses (Mann-Whitney $U$ test, $p<.05$ )

4.1 Voucher list for all species used in this study, includes GPS and geographical data. 


\section{CHAPTER I: INTRODUCTION INTO THE THESIS AND THE GENUS DARWINIOTHAMNUS}

\section{General Introduction:}

The origin of species endemic to oceanic islands has fascinated evolutionary biologists ever since the pioneering work of Charles Darwin's publication on the origin of species (Darwin, 1859). However, tracing the origin of insular endemics based on morphological data can be trying because of the major morphological shifts that typically occur after long distance dispersal and insular diversification (Givnish and Systma, 1997, Carlquist, 1965, 1974, 1995, Aradhya et al, 1991, Rees, et al. 2001, Fuertes-Aguilar et al. 2002). Darwiniothamnus (Asteraceae: Astereae), one of the seven plant genera endemic to the Galápagos Islands, is a model example of this situation.

Darwiniothamnus, as currently defined, comprises three species of suffrutescent (D. alternifolius) to woody (D. tenuifolius and D. lancifolius) perennials, which can be found on seven major islands throughout the archipelago. The genus ranges from coastal beach strands to mesic or humid scrub and forestlands, through lava and scoria fields and up to high elevation fern and sedge zones. Morphologically, these taxa are considered to be highly divergent from their continental relatives and have been suggested to be most closely related to woody Chilean members of the genus Erigeron (Asteraceae: Astereae) (Harling, 1962). Until recently, however, there have been no molecular studies completed on Darwiniothamnus in regards to finding its origin and clarifying its relationship to other taxa. Thus, there exists a serious need for a rigorous phylogenetic study on this genus in order to confirm or disprove the monophyly of Darwiniothamnus 
and to clarify the existing relationships between this genus and its putative South American relatives.

This thesis is composed of three interrelated, yet independent papers, each addressing several topics critical to the conservation and taxonomy of all species of Darwiniothamnus. The introduction is followed by a discussion of the history of research on Darwiniothamnus, which includes a review of historical taxonomical and morphological treatments. This section is followed by the purpose and design of my study, which incorporates the specific investigative questions that I aimed to answer during the course of master's research.

Chapter 2 contains information on the natural history of the Galápagos Islands; included is a brief summary of the geological history of the archipelago and a synopsis of its climatic patterns and vegetation zones. This section is followed by an outline of the most relevant botanical collections within the Galápagos Islands over the past 150 years. An epigrammatic review of plant endemism within the archipelago is discussed in the next section with notes on rarity, radiation and sources of origin. Finally, the scope of this topic is narrowed further by a discussion of the endemic members of the Asteraceae within the Galápagos Islands, including information on taxonomy, morphology and phylogenetics. Notes on the ecology, habitat and conservation status are also reviewed for each of these endemic taxa, with projections on the future status of these genera within the archipelago.

Chapter 3 is composed of a discussion of my field observations, which were conducted from April $1^{\text {st }}$-July $1^{\text {st }}, 2002$. The first section deals with the distribution and habitat types of all populations that I encountered while in the field, throughout several 
different islands. The second section covers the various factors currently threatening the survival of the extant populations of Darwiniothamnus. In specific, this section discusses the effects of foraging animals and human population growth and includes information on the deleterious effects caused by the current infestation by the cottony cushion scale insect, Icerya purchasi Maskell (Homoptera: Margarodidae), which is perhaps the single most detrimental organism in contact with Darwiniothamnus. This chapter is closed with a discussion of my soil observations and analyses where I hypothesize on how the different soil types throughout the archipelago may have an effect on the successful introduction of Darwiniothamnus in previously unpopulated areas.

Chapter 4 is dedicated to the origin and phylogenetics of Darwiniothamnus. The first section of this chapter provides a brief history of research on the tribe Astereae; including notes on its distribution, morphological characteristics, and recent phylogenetic analyses performed on various members of the tribe. This section is followed by a review of the Erigeron-Conyza complex, which is a group comprising 24 closely related genera (including Darwiniothamnus) that are rather small in comparison to the size of Erigeron and Conyza, for which this complex is named. The final section of this chapter, before the introduction into the phylogenetics of Darwiniothamnus is covered, contains a brief discussion of the value of using the Internal Transcribed Spacer region (ITS) of nuclear ribosomal DNA (nrDNA) in various phylogenetic studies.

It should be noted that the second, third and fourth chapters of this thesis are intended to be published independently and thus contain their own reference sections at the end of each chapter. The same format applies to figures and tables, which are numbered consecutively for each chapter, where the first number refers to the chapter and 
the number following the period refers to the individual figure or table (e.g. Table 2.3, refers to Chapter 2, Table 3). Only the appendices for all the chapters are grouped together at the end of the thesis.

\section{History of Research on Darwiniothamnus:}

\section{i. History of taxonomy and morphology}

Members of the genus Darwiniothamnus were first described by J. D. Hooker (1847), who considered them to be part of Erigeron based primarily on floral characters taken from Darwin's collections, made some twelve years earlier. Hooker (1847) named the two species collected by Darwin E. tenuifolius and E. lancifolius. Although Erigeron has always been given a rather wide circumscription (Bentham and Hooker, 1873; Hoffman, 1894), the two Galápagos endemics were sufficiently morphologically divergent that both Bentham and Hooker (1873) and Andersson (1857) wrote about the unusual woody habit of these two species in comparison to other members of the genus. However, despite several differences in leaf form and plant size between these two new species and other members of Erigeron, the general structure of the inflorescences and flowers was sufficiently similar for Hooker to warrant grouping them together. This treatment, and Hooker's description of E. tenuifolius and E. lancifolius, were generally followed by several botanists familiar with the flora of the Galápagos for many years until Harling (1962) published his review "On some Compositae endemic to the Galápagos Islands."

Harling (1962) was the first to describe the woody composites of the Galápagos in detail and was the first to transfer E. tenuifolius and E. lancifolius into their own genus, Darwiniothamnus. Harling's initial reason for the transfer of these species into 
Darwiniothamnus was based on his own morphological research, where he found detailed differences in characters belonging to the inflorescences, flowers, fruits, and the formation and development of the embryo-sac. Indeed, he felt these differences were great enough to remove the two Galápagos species from Erigeron, even though both Stewart (1911) and Christophersen (1932) had previously stated that material of $E$. tenuifolius tended to be rather variable in basic morphology.

Harling (1962) and his colleague Fagerlind (in Harling, 1962) continued to delve further into the embryological conditions of E. tenuifolius and E. lancifolius, and found that the two species of Darwiniothamnus also differed from other members of Erigeron in that they had monosporic embryo sac development and a persistent unicellular archespore. Interestingly, these two unique embryological conditions were actually very similar certain species of Conyza, however the two new species of Darwiniothamnus differed from this genus too, in that they lacked secondary cell divisions in the antipodes (Harling, 1962).

In addition to his embryological work, Harling (1962) found other differences between the species of Darwiniothamnus and those of Erigeron. For example, the former's involucres were described as "narrowly companulate or obconical" while the latter were "hemispherical to broadly campanulate." The number of phyllaries also differed, where the former had strongly imbricate and unequal phyllaries in series of 4-6, and the later had subequal or imbricate phyllaries in series of 2-3. Finally, Harling (1962) found three additional discrepancies for which to base his removal of $E$. tenuifolius and E. lancifolius from the rest of the genus: 1) The receptacle of all other South American species of Erigeron was "alveolate and sometimes "fimbriate"" (Solbrig, 
1960), whereas the species from the Galápagos were "minutely papillose but not or only indistinctly alveolate;"2) The ray flowers were typically twice as many as the disk flowers in the Galápagos species whereas the opposite was found in the rest of the genus; 3) The two Galápagos species had "slightly but distinctly" dimorphic achenes, while the rest of the genus did not.

These differences were enough to convince Harling (1962) that Darwiniothamnus should exist as a separate genus from Erigeron; and he described it as containing two species, namely $D$. tenuifolius and $D$. lancifolius. He continued to further split these two species into four subspecies: D. tenuifolius ssp. tenuifolius from Floreana, Santíago, Pinta, Pinzón, and Isabela; D. tenuifolius ssp. santacruzianus from Santa Cruz; D. lancifolius ssp. lancifolius from south Isabela, and D. lancifolius ssp. glandulosus from north Isabela and Fernandina. Harling (1962) also mentioned that although he did not get the opportunity to study Stewart's (1911) type of D. lancifolius var. glabriusculus, he felt it may be worth retaining as a variety.

Unfortunately, the treatment of the genus Darwiniothamnus did not stop there, as several other taxonomists continued to comment of the placement of its two species (see Table 1.1). For example, around the same time Harling (1962) published his review of the Galápagos endemics, Solbrig (1962) was revising the South American species of Erigeron. Solbrig (1962) mentioned that the Galápagos species might deserve being described as their own genus, but refrained from doing so because of a lack of material. He did, however, suggest that $E$. lancifolius ought to be considered a subspecies of $E$. tenuifolius, and by doing so confounded the taxonomical treatments of Darwiniothamnus for years to come. 
Over the next ten years new material provided by additional collection trips to the Galápagos led Cronquist $(1970,1971)$ to rebut Harling's previous hypotheses and to suggest lumping all of the morphological variants into a single variable species, $D$. tenuifolius, with three varieties: D. tenuifolius var. tenuifolius from Floreana, Pinta, Pinzón, Santíago and Santa Cruz; D. tenuifolius var. glabriusculus (Stewart) Cronquist from Isabela, and D. tenuifolius var. glandulosus (Harling) Cronquist from north Isabela and Fernandina. Although Cronquist (1970) did not provide any specific explanation for his decision to lump all of these taxa into one variable species, Wiggins and Porter (1971) chose to follow his treatment when publishing their flora of the Galápagos Islands, listing the genus as monotypic with the three varieties described above.

Sixteen years later Lawesson and Adsersen (1987) described yet another new species of Darwiniothamnus, D. alternifolius, which they discovered on the volcanoes of Sierra Negra and Cero Azul on the southern tip of Isabela. They felt this new species warranted inclusion within Darwiniothamnus because "the type flowers while still herbaceous, look very similar to Erigeron or Conyza... [the habit] gradually becomes shrubby [and] as it has many ray florets, imbricate phyllaria of unequal length, slightly dimorphic achenes and is aromatic, it is clearly within the generic limits of Darwiniothamnus." Lawesson and Adsersen (1987) continued to point out, however, that several differences did exist between their type specimen and the other species of the genus, as can be seen in Table 1.2.

Lawesson and Adsersen (1987) went on to state that most botanists with field experience in the Galápagos agree that Cronquist's reduction was probably exaggerated, and thus chose to rename most of the species previously delineated by Harling (1962), 
Hooker (1847), Cronquist $(1970,1971)$ and Solbrig (1962), to: D. tenuifolius (Hooker fil.) Harling from Floreana, Isabela, Pinta, Pinzon and Santiago; D. lancifolius ssp. lancifolius (Hooker fil) Harling from Tagus Cove, Isabela; D. lancifolius ssp. glandulosus Harling from the higher elevations of Volcan Darwin, Isabela and throughout Fernandina; and D. lancifolius ssp. glabriusculus (Stewart) Lawesson \& Adsersen, from the area on and near Volcan Sierra Negra, Isabela.

The taxonomy of Darwiniothamnus has remained contentious, as different authors have listed it as having 2,3, or 4 species, each with their own subspecies and/or varieties (see Table 1.1). In addition, although Harling's (1962) description of Darwiniothamnus may appear to have been adequate, he may have made a couple of critical mistakes when first describing the subspecies of $D$. lancifolius. For example, Harling was incorrect in stating that $D$. lancifolius ssp. lancifolius hailed from southern Isabela, as the taxon lancifolius was originally described from material from northern Isabela (Hooker, 1847). Thus, Harling may have started the nomenclatural confusion for this genus when he included Darwin's type (which was almost certainly from Tagus Cove on the northwestern edge of Isabela) and material from Sierra Negra (located on the southernmost tip of Isabela) in the same taxon D. lancifolius ssp. lancifolius. This carries the implication that each subspecies pair (lancifolius/glabriusculus and lancifolius/glandulosus) has broadly overlapping ranges, which obviously makes little biogeographical sense. However, if the ranges of the subspecies that Harling (1962) described are indeed more restricted, then the name lancifolius ought to belong to the type locality population at Tagus Cove; although it appears that after having personally searched this area extensively, the population that Darwin once collected is now extinct 
and the only taxon that remains anywhere on or near Volcan Darwin is D. lancifolius ssp. glandulosus. In lieu of all of this, it could still be worth retaining the subspecies epithet "lancifolius," as Darwin's type specimen for this taxon (located at CGE) is definitely morphologically different from D. lancifolius ssp. glandulosus and D. lancifolius ssp. glabriusculus. However, a rigorous morphological study must be completed before the taxonomical confusion of this genus can be sorted out once and for all.

Regardless of its circumscription, however, the genus Darwiniothamnus continues to thrive in a variety of habitats within the Galápagos Islands, ranging from lava fields to the moist highlands of several different islands. In general, each of the species in this genus are differentiated from one another by their leaf shape (as all members of the genus have leaves that are thick, glabrous to tomentose, and aromatic), and degree of woodiness. In specific, D. lancifolius has leaves that are lanceolate to broadly lanceolate and the plant can range from a small shrub to large bush spanning 1-2 meters, with a rather thick and woody trunk. D. tenuifolius has almost needle-like leaves and the same woody, shrub-like appearance of $D$. lancifolius, except it tends be more erect, sometimes reaching a height of 1-2 meters. Finally $D$. alternifolius has leaves that alternate and not clustered near the branch tips like the other two species, and it is almost always a small herbaceous plant with only a slightly woody stem. The flowers of all the species of Darwiniothamnus are also very similar, with white to purplish-white ray flowers and yellow disk flowers. Both the flowers and fruits in all species persist for several weeks and are often seen being eaten by birds. It should also be noted that the numerous, pappus-bearing fruits are very light, making them apt for both wind or bird dispersal (Lawesson and Adsersen, 1987.) 
It has been suggested by Harling (1962) that the closest relatives of Darwiniothamnus are probably the Chilean Erigeron berterianus DC. and E. litoralis (Phil.) Skottsb. However, the molecular phylogeny presented in this thesis suggests that two members of the genus may actually be closer to E. bellidiastroides of the Caribbean (see Chapter 4). Chromosome counts have not been performed on this genus, and the results of my molecular phylogenetic data suggest that Darwiniothamnus should be regrouped within Erigeron, just as Solbrig mentioned in 1962 (see Chapter 4 for a detailed explanation).

\section{ii. Purpose of study}

Island ecosystems have often been considered to be biodiversity hotspots as they are generally species poor for their size, rich in forms found no place else and collectively contribute disproportionately for their area to global species totals. Because all of these peculiarities are typical of island biotas, it makes them fascinating environments on which to perform a study in molecular plant systematics. Schilling et al. (1994) has stated that the "study of island endemics is of particular interest for evolutionary biologists, and possession of information on their phylogenetic relationships is critical to resolving questions regarding their place and time of origin that would allow new insights into evolutionary processes." In addition, Hamann (1990) outlined a list of characteristics typical of oceanic islands which describes why they should be of particular interest in terms of importance to conservation:

1. The high degree of endemism that occurs on islands gives them a disproportionately large contribution to the diversity of species and ecosystems of the world. 
2. The peculiar adaptations which occur on islands, including a loss of dispersal ability for plants and flightlessness for birds, poorly prepare the organisms for survival in the face of habitat changes, human interference and exotic herbivores or predators, thereby increasing their vulnerability to extinction.

3. Islands are seldom well endowed with natural resources, which typically are scarce in variety and quantity, and thus are particularly liable to overexploitation and mismanagement. Stated simply, islands are environmentally fragile.

4. Because of their scarcity, fragility and vulnerability of natural resources, islands require different approaches to ensure a continuous flow of raw materials, goods, and services needed by their inhabitants.

5. Although islands face important and unique difficulties they also may serve as a resource for improving approaches to conservation management. Indeed, pilot studies carried out in islands under relatively simple conditions, where the limits to the ecosystems are clear, may point to solutions to problems also faced on larger, continental scales. Therefore, islands such as the Galápagos share not only problems but also opportunities with other oceanic islands.

With all of this said, the importance of island studies in general becomes apparent, but what of molecular phylogenetic studies on the flora of the Galápagos in specific? Unfortunately, only a few studies have used molecular data in the past to assess the origin and evolution of plants from the Galápagos. Rick and Forbes (1975), Wendel and Percival (1990), and Elisens (1992) used allozyme data to compare members of Lycopersicon (Solanaceae), Gossypium (Malvaceae), and Galvezia (Scrophulariaceae), respectively, to potential Andean congeners. Wendel and Percival (1990) have also provided allozyme and cpDNA restriction site data suggesting a species of Gossypium endemic to the Galápagos is of north Mexican descent; and as noted earlier, Schilling (1994) was the first to compare the genus Scalesia with several potential South American sister groups from within the tribe Helianthinae. More recently, Miller (2002) studied gender dimorphism in the genus Lycium (Solancaceae) by looking at the phylogenetic relationships within the genus, and used Nolana galapagensis (Solanaceae) of the Galápagos as one of the six outgroups. Besides these few studies, however, no other 
molecular work has been performed on the native or endemic taxa of the Galápagos Islands.

Until recently, the same could be said for Darwiniothamnus, as both its origin and relationship to potential sister taxa were uncertain. Thus, there existed a significant need for a rigorous phylogenetic study on this genus in order to confirm or disprove the existing morphological hypotheses regarding its relationship with putative South American relatives, and therefore the research described in Chapters 3 and 4 was performed.

\section{iii. Research Questions}

The following is a list of questions that were assembled for my Master's thesis both while in the lab and in the field. Detailed morphological analyses and chromosome counts on all members of the genus had to be postponed as it became apparent that this was outside the scope and time range of a typical master's project. Both of these analyses will be performed in the near future, however, and may serve to complement or disprove some of the author's hypotheses discussed in the following chapters.

1. What is the conservation status of all currently recognized taxa within the genus Darwiniothamnus and do any new conservation measures need to be implemented?

2. Based upon field observations, do any areas contain new morphological variants that warrant in-depth morphological analyses?

3. What are the existing biological threats to Darwiniothamnus and what can be done to protect these populations in the future?

4. Does the lack or over-abundance of certain essential elements and/or micronutrients prevent Darwiniothamnus from colonizing certain areas of the archipelago?

5. Where is the origin of Darwiniothamnus and is the genus monophyletic? 
Detailed answers to each of these questions can be found within the next the next three chapters and a precise discussion on each of the topics can also be found in the "Concluding Remarks" section at the end of Chapter 4.

Table 1.1: Synopsis of recent taxonomic classification by various authors

\begin{tabular}{|l|l|l|l|l|l|l|l|l|}
\hline Species Recognized & Ho & St & Ch & Ha & So & Cr & W \& P & L\& A \\
\hline Erigeron lancifolius & $\mathrm{X}$ & $\mathrm{X}$ & $\mathrm{X}$ & & & & & \\
\hline Erigeron tenuifolius & $\mathrm{X}$ & $\mathrm{X}$ & $\mathrm{X}$ & & $\mathrm{X}$ & & & \\
\hline E. tenuifolius ssp. lancifolius & & & & & $\mathrm{X}$ & & & \\
\hline E. lancifolius var. glabriusculus & & $\mathrm{X}$ & & & & & & \\
\hline E. tenuifolius var. tomentosus & & $\mathrm{X}$ & & & & & & $\mathrm{X}$ \\
\hline Darwiniothammus tenuifolius & & & & $\mathrm{X}$ & & & & $\mathrm{X}$ \\
\hline Darwiniothamnus lancifolius & & & & $\mathrm{X}$ & & & & $\mathrm{X}$ \\
\hline Darwiniothamnus alternifolius & & & & & & $\mathrm{X}$ & $\mathrm{X}$ & \\
\hline D. tenuifolius var. tenuifolius & & & & & & $\mathrm{X}$ & $\mathrm{X}$ & \\
\hline D. tenuifolius var. glabriusculus & & & & & & $\mathrm{X}$ & $\mathrm{X}$ & \\
\hline D. tenuifolius var. glandulosus & & & & & & & & \\
\hline D. tenuifolius ssp. santacruzianus & & & & $\mathrm{X}$ & & & & $\mathrm{X}$ \\
\hline D. lancifolius ssp. glandulosus & & & & $\mathrm{X}$ & & & & \\
\hline D. lancifolius ssp. glabriusculus & & & & $\mathrm{X}$ & & & & \\
\hline
\end{tabular}

Where: $H o=$ Hooker $(1847)$

$\mathrm{St}=$ Stewart (1911)

$\mathrm{Cr}=$ Christophersen (1932)

$\mathrm{Ha}=$ Harling (1962)

So $=$ Solbrig (1962)

$\mathrm{Cr}=$ Cronquist $(1970,1971)$

W \& P = Wiggens and Porter 
Table 1.2: Description of the species of Darwiniothamnus:

\begin{tabular}{|c|c|c|c|c|}
\hline Taxon & Leaf position & Leaf shape & Fruit type & Inflorescence type \\
\hline D. alternifolius & $\begin{array}{l}\text { not condensed in } \\
\text { terminal whorls; } \\
\text { Internodes half the } \\
\text { length of the leaves } \\
\text { or longer }\end{array}$ & $\begin{array}{l}\text { broadly } \\
\text { lanceolate to } \\
\text { spatulate }\end{array}$ & $\begin{array}{l}\text { all achenes } \\
\text { two nerved }\end{array}$ & $\begin{array}{l}\text { synflorescence } \\
\text { cymiformly branched, } \\
\text { clearly exceeding terminal } \\
\text { terminal leaves. } \\
\text { involucrum abruptly } \\
\text { limited downwards }\end{array}$ \\
\hline D. tenuifolius & $\begin{array}{l}\text { leaves terminally in } \\
\text { condensed whorls; } \\
\text { Internodes much shorter } \\
\text { than half the leaf length }\end{array}$ & $\begin{array}{l}\text { filiform, linear } \\
\text { or narrowly } \\
\text { lanceolate }\end{array}$ & $\begin{array}{l}\text { achenes of } \\
\text { disk florets } \\
\text { with } 3 \text { to } 6 \\
\text { nerves }\end{array}$ & $\begin{array}{l}\text { heads solitary or on } \\
\text { somewhat branched } \\
\text { peduncles in terminal } \\
\text { axils, forming corymbi- } \\
\text { form synflorescences } \\
\text { hardly exceeding terminal } \\
\text { leaf whorl } \\
\text { involucrum gradually } \\
\text { terminating with bracts } \\
\text { downwards on the pedicel. }\end{array}$ \\
\hline D. lancifolius & $\begin{array}{l}\text { leaves terminally in } \\
\text { condensed whorls; } \\
\text { Internodes much shorter } \\
\text { than half the leaf length }\end{array}$ & $\begin{array}{l}\text { lanceolate } \\
\text { to broadly } \\
\text { lanceolate }\end{array}$ & $\begin{array}{l}\text { achenes of } \\
\text { disk florets } \\
\text { with } 3 \text { to } 6 \\
\text { nerves }\end{array}$ & $\begin{array}{l}\text { heads solitary or on } \\
\text { somewhat branched } \\
\text { peduncles in terminal } \\
\text { axils, forming corymbi- } \\
\text { form synflorescences } \\
\text { hardly exceeding terminal } \\
\text { leaf whorl } \\
\text { involucrum gradually } \\
\text { terminating with bracts } \\
\text { downwards on the pedicel. }\end{array}$ \\
\hline
\end{tabular}




\section{REFERENCES}

Andersson, N.J. 1857. Om Galápagos Oarnes Vegetation. Kongl. Svensk. Vet. Akad. Handl. 1857: 1-114.

Aradhya, K. et al. 1991. Genetic evidence for recent and incipient speciation in the evolution of Hawaiian Metrosideros (Myrtaceae). Heredity 67: 129-138

Bentham, G. and Hooker, F. 1873. Notes on the Classification, History and Geographic distribution of Compositae. Jour. Linn. Soc. Bot. 13: 335-577.

Carlquist, S. 1965. Island Life. New York: The Natural History Press.

Carlquist, S. 1974. Island Biology. New York: Columbia Univ. Press.

Carlquist, S. 1995. Introduction to Hawaiian biogeography: evolution on a hot spot archipelago. eds. V. A. Funk, and W. L. Wagner. Washington, DC: Smithsonian Institution Press.

Christophersen, E. 1932. A collection of plants from the Galápagos. Nyt Mag. Naturvidensk. 70: 67-97.

Cronquist, A. 1970. New combinations in the Compositae of the Galápagos Islands. Madroño 20: 255-256.

Cronquist, A. 1971. Compositae. - In :Wiggins, I.R. and Porter, D. M. (eds.) Flora of the Galápagos Islands. Stanford University Press, Stanford, pp. 300-367.

Darwin, C. 1859. On the origin of species. London, England: Murray.

Elisens, W. J. 1992. Genetic divergence in Galvezia (Scrophulariaceae) evolutionary and biogeographic relationships among South American and Galápagos species. Amer. Jour. Bot. 79: 198-206.

Fuertes-Aguilar, J. 2002. Molecular evidence from chloroplast and nuclear markers for multiple colonizations of Lavatera (Malvaceae) in the Canary Islands. Sys. Bot. 27: 74-83.

Givnish, T. and Sytsma, K. 1997. Molecular Evolution and Adaptive Radiation Cambridge: Cambridge University Press.

Hamann, O. 1990. Research and management in the Galápagos: Some Botanical Considerations. Monogr. Syst. Bot. Missouri Bot. Gard. 32: 5-10. 
Harling, G. 1962. On some Compositae endemic to the Galápagos Islands. Acta Hort. Bergiana 20: 63-120.

Hooker, J. D. 1847. On the Vegetation of the Galápagos Archipelago, as compared with that of some other Tropical Islands and of the Continent of America. Trans. Linn. Soc. 20: 235-262.

Lawesson, J.E. and Adsersen, H. 1987. Notes on the endemic genus Darwiniothamnus Harling (Asteraceae, Astereae) from the Galápagos Islands. Op. Bot. 92: 7-15.

Miller, J. 2002. Phylogenetic relationships and the evolution of gender dimorphism in Lycium (Solanaceae). Sys. Bot. 27: 416-428.

Rees, D., et al. 2001. Reconciling gene trees with organism history: the mtDNA phylogeography of three Nestoes species (Coleoptera: Tenebrionidae) on the western Canary Islands. J. Evol. Biol. 14: 139-147.

Rick, C. M. and J. F. Forbes. 1975. Allozymes of Galápagos tomatoes: polymorphism, geographic distribution, and affinities. Evolution 29: 443-457.

Schilling, E. et al. 1994. Evidence from chloroplast DNA restriction site analysis on the relationships of Scalesia (Asteraceae: Heliantheae). A.J.B.

81: 248-254.

Solbrig, O. 1960. The South American sections of Erigeron and their relation to Celmisia. Cont. of Gray Herb. 188: 65-85.

Solbrig, O. T. 1962. The South American species of Erigeron. Contr. Gray Herb. 191: 379.

Stewart, A. 1911. Expedition of the California Academy of Sciences to the Galápagos Islands 1905-1906. A botanical survey of the Galápagos Islands. California Academy Press. San Francisco, California.

Stewart, A. 1911. A botanical survey of the Galápagos Islands. Proc. Cal. Acad. Sci. IV, 1: 7-288.

Wendel, J. F. and Percival, A. E. 1990. Molecular divergence in the Galápagos IslandsBaja California species pair, Gossypium klotzschianum and G. davidsonii (Malvaceae). Plant Sys.Evol. 171: 99-115.

Wiggins, I and Porter, D. (1971) Flora of the Galápagos Islands. Stanford University Press. Stanford, CA. 


\section{CHAPTER II: NATURAL HISTORY OF THE GALÁPAGOS ISLANDS:}

\section{Geology/age of the Galápagos Islands:}

The Galápagos Islands, situated on the equator between $1^{\circ} 25^{\prime} \mathrm{S}-1^{\circ} 40^{\prime} \mathrm{N}$ latitude and $89^{\circ} 14^{\prime}-92^{\circ} 01 \mathrm{~W}$ longitude, lie about $960 \mathrm{~km}$ off the coast of Ecuador in the eastern Pacific Ocean. The age of the Galápagos archipelago has never been determined exactly and what exists of fossil material is almost all from the Pleistocene age, ca. 1.8 mya (Jackson, 1976). It is generally accepted that the westernmost islands (west of the Darwin-Española fault line) are slightly less than a million years old and the easternmost islands are somewhat older. In general, estimates such as these are based on preliminary investigations of shifts in the magnetic polarity of lava that has cooled in place, and the values vary greatly depending upon the author (Christie et al. 1992; Davis et al. 1995). A more detailed study by Cox (1983) based on geomagnetic reversal stratigraphy to age most of the major islands, suggested that Santa Cruz and San Cristóbal are amongst the oldest islands at about $4.2 \pm 1.8$ and 4.5 million years old respectively. The youngest islands were determined to be Isabela and Fernandina at approximately 0.09-0.5 million years old.

All of the Galápagos Islands are volcanic in origin, comprising the top of the Carnegie Ridge, which is a submarine mountain range that extends eastward from the Galápagos almost to the mainland. In addition, the entire archipelago is situated beyond the continental shelf just south of the divergent plate boundary separating the Nazca and Cocos Plates. This divergent plate boundary is the origin of an underwater line of ridges and chasms known as the Galápagos Rift, which is an area of intense geological activity 
that most likely played an important role in the formation of the Galápagos (Jackson, 1993).

In total, the archipelago comprises 13 major islands and several smaller islets and rocks, which altogether encompass an area of $7900 \mathrm{~km}^{2}$. All of the islands within the archipelago contain topographic characteristics in accordance with Whittaker's (1998) definition of a true volcanic island, which he states are steep, relatively high for their area, and become highly dissected over time. Jackson (1993) has mentioned that although the most dramatic features of Galápagos geology relate to constructive volcanic processes, erosion via wind, the ocean, and rain have altered much of the Galápagos landscape as well. In the Galápagos, the shapes of ash rings and scoria cones can be used as a rough guide to direction since the prevailing winds come from the southeast and generally lead to more erosion on that side. It is thus also likely that the prevailing winds could cause more material to be deposited on the northwest side during an eruption, which may have had a bearing on the general shape of many of the islands and their volcanoes. In addition to erosion, some parts of the general topography of the archipelago are not solely due to volcanic eruptions, but instead to uplifting and subsidence. The presence of the islands of Seymour, Baltra, Plazas and parts of the northeast coast of Santa Cruz are most likely due to uplifting which is the result of subsurface movements of magma (Jackson, 1993). Subsidence, on the other hand, results in the formation of calderas and pit-craters, such as can be seen in los Gemellos, on the island of Santa Cruz.

It should also be noted that the entire archipelago is steadily moving in a southeastern direction at more than $7 \mathrm{~cm} /$ year and the present islands are expected to 
disappear into the Chile-Peru Trench about 20 million years from now, due to spreading of the sea floor along the Galápagos Rift and through the Carnegie Ridge (Cox, 1983 and Jackson, 1976). There is no evidence that suggests the archipelago was ever connected with the continent by an above-water land bridge, even though Banfield et al. (1956) have noted that the bottom topography of the ocean between the islands and the mainland is not fully known. The existence of such a bridge could have served for the transfer of any number of species from the mainland to the Galápagos Islands.

It is generally accepted that at least some of the islands within the archipelago were connected to each other when the Pleistocene ice sheets were at their maximum volume of about 77 million $\mathrm{km}^{3}$ and the sea level was about 120 meters below the current level (Jackson, 1993). Such glacial advances, and their subsequent retreats, no doubt played an important role in the evolution and distribution of several Galápagos species within the archipelago.

\section{Climate and vegetation types:}

The Galápagos Islands are situated at the point of convergence of the principal ocean currents of the eastern Pacific and are annually influenced by the warm Panama current from the north, formerly known as "E1 Niño." They are also periodically affected by what have now come to be known as El Niño Southern Oscillation (ENSO) events, which are currents that influence the islands for an unusually protracted period of time, bringing exceptionally heavy rains to the archipelago. Due to their unique placement, the lowlands of the archipelago are quite arid while the highlands are generally moist. The archipelago has a mean annual precipitation range of 0-300 $\mathrm{mm}$ at the coast, and about 2000 or more in the mountains (Jackson, 1993; Alan Tye, personal communication). In 
general, the air temperature on the islands reflects that of the sea water temperature, and there are only two distinct seasons. Due largely to the Humboldt current from the Antartic, there is a cold season that lasts from July to December, and a warm season that exists during the rest of the year.

Historical climate change is known to dictate the course of botanical diversity over time in the Galápagos and throughout the world. As previously mentioned, the lower regions of the archipelago are typically desert-like and the highlands are moist where expansive forests occur. However, paleo-environmental data from lake sediments demonstrate that in the last glacial period the highlands were also dry (Whittaker, 1998). The familiar moist conditions returned to the highlands around 10,000 BP, and pollen data for El Junco Lake on Isla San Cristóbal indicate a lag of some 500-1000 years before the vegetation similar to that of the present day occupied the moist high ground (Colinvaux, 1972). Whittaker (1998) has stated that this delay may reflect the slow progress of primary succession after the expansion from relict populations in small refugia in more moist valleys, or the necessity of many plants having to disperse over wide sea gaps to reach the site. Today the vegetation of the archipelago can be divided into seven, easily characterized vegetation zones: the littoral, arid, transition, Scalesia, Miconia, brown, and fern-sedge zones. Each of these zones is primarily divided by a difference in plant species, increasing levels of rainfall over an altitudinal gradient, and depth of soil (see Figure 2.1).

\section{Summary of Botanical Collections from Darwin to present:}

The Galápagos Islands were first visited by Bishop Fray Tomás de Berlanga, the fourth Bishop of Panamá, in 1535. Tomás de Berlanga discovered the islands by accident 
when attempting to sail to Puerto Viejo, Ecuador, when he instead drifted to the Galápagos due to a lack of wind power (Wiggins and Porter, 1971). He wrote little about the plant life on the islands and mentioned only that his crew chewed cactus pads for liquid nourishment, although no known collections of such plants were made. The first real scientific exploration of the Galápagos Islands began in the early nineteenth century by British botanists such as Douglas and Scouler in 1825 (Robinson, 1902), Macrae in 1825, and Cuming in 1829 (Howell, 1941). Each of these collections yielded only a few specimens as many of the collectors had trouble transporting the specimens back to Europe or accidentally lost them along the way (see Table 2.1).

The first major collection of Galápagos flora was made by Charles Darwin in 1835, who collected over 200 specimens, two of which (Sicyos villosa and Delilia inelegans) are now considered to be extinct endemic species of which only Darwin's type collection exists (Hooker, 1847). During the month that Darwin spent in the Galápagos he collected vascular plants on the islands of Isabela, San Cristóbal, Santíago, and Floreana. Of the 209 plants which Darwin collected, $74 \%$ of them were new records for the archipelago. All of these specimens, including a few added by Scouler, Douglas, Macrae and Cuming were the basis of J.D. Hooker's (1847) seminal work on Darwin's specimens and the vegetation of the Galápagos Islands.

During the middle of the nineteenth century a few additional collections were made by Petit-Thouars and Neboux, from France, in 1838; and by Edmonstone and Goodridge, from England, in 1846 (Wiggins and Porter, 1971). These two collections represent a total of 46 taxa (Petit-Thourars and Neboux $=5$ and Edmonstone $\&$ Goodridge $=41$ ) of which 24 (Petit-Thourars and Neboux $=3$ and Edmonstone \& 
Goodridge $=21$ ) were new records for the archipelago (see Table 2.1). In $1852 \mathrm{~N}$. J. Andersson, a Sweedish scientist, spent ten days in the Galápagos and collected 329 specimens that further contributed to the growing knowledge of the Galápagos flora. Thirty-one percent of Andersson's collecting effort represented new records for the islands and he successfully published 50 as new species (Andersson, 1857).

The end of the nineteenth and beginning of the twentieth centuries were marked by the following major and minor contributing collectors: Habel in 1869 (Robinson, 1902), Hill and Steindachner in 1872 (Wiggins and Porter, 1971), Wolf in 1875 (Wolf, 1875), Chierchia and Marcacci in 1884 (Wiggins and Porter, 1971), Lee in 1888 (Wiggins and Porter, 1971), Agassiz in 1891 (Wiggins and Porter, 1971), Baur in 1891 (Baur, 1891; and in Robinson \& Greenman, 1895), Snodgrass and Heller in 1899, Stewart from 1905-1906 (Stewart, 1911), Rorud from 1926-1927 (Christophersen, 1932), Svenson in 1930 (Svenson, 1935), and Howell in 1932 (Howell, 1933, 1941, 1968). These explorers hailed from England, Italy, Germany, the USA and Sweden; and although the collection numbers for several of these explorers was quite high, the number of newly reported species was often low (see Table 2.1). This is most likely due to the fact that most of the native flora of the Galápagos Islands was already described by the early 1900's. Of these early collectors, Rorud was the first Galápagos resident to collect and catalog Galápagos plants and Baur was the first to visit 13 of the islands and collect many of the plants that had not been seen since Darwin's day (Porter, 1971).

The first two significant explorations to cover almost all reaches of the archipelago were the Hopkins and California Academy of Sciences expeditions, (McMullen, 1999). Each expedition had their own team of well-trained botanists, with 
Snodgrass and Heller (Robinson, 1902) as the acting botanists in the former and Stewart (Stewart, 1911) being responsible for plant collecting in the latter. Both of these expeditions cataloged several new members of the Galápagos flora and fauna, the largest plant collections of which can be found at the Gray and California Academy of Sciences Herbaria, respectively.

Due to the economic tensions produced by World War I, the next collecting expedition to the Galápagos was not until 1923. The Harrison Williams Galápagos Expedition was described in detail by Beebe (1924), and both his and his colleagues' collections are held in the New York Botanical Garden (NY). Over the next eight years four additional collecting expeditions began in the Galápagos, the Norwegian Zoological Expedition, a British group aboard the yacht St. George, the British Vincent Astor and the Templeton Crocker Expeditions. All of the botanists in each of these expeditions amassed large collections from a variety of islands and what exists of the details from these collection trips is described in the papers by Christophersen (1932), Riley (1925), Svenson (1935), and Howell (1933abc, 1934ab, 1937, 1941ab), respectively.

Harling (1962) began the postwar period of publication on Galápagos botany and performed the first major work to detail solely the endemic members of the Asteraceae in the archipelago. In addition, Harling and his field collaborators also collected a total of about 1,600 specimens across several plant families that are now housed in Sweden's Naturhhistoriska Riksmuseet's herbarium (S). After Harling's 1962 publication and before the publication of the flora by Wiggins and Porter in 1971 (the first modern flora describing a total of 107 families, 348 genera, 642 species and 60 species and varieties), close to 70 different scientists visited and collected both plant and animal specimens on 
the islands. Many of these visits were the result of the opening of the Charles Darwin Research Station (CDRS) in 1964. The CDRS now encompasses active labs with resident and visiting research scientists who continue to study the flora and fauna of the Galápagos Islands.

Over the past forty years, new records of vascular plants in the Galápagos continue to have been published by Eliasson (1972), Weber (1973), Hamann (1974), Wiggins (1975), Adsersen ( 1976 a,b), Van der Werff (1977), and Lawesson and Adserson (1987) among others. A botanical bibliography has also been published by Schofield (1973) and a treatment of the endemic genera within the archipelago is discussed in this paper below.

\section{Review of plant endemism within the archipelago - rarity, radiation and sources of origin:}

Of the 500-560 native plant species and 550-610 native plant taxa in the Galápagos (60 are uncertainly native), close to 180 species and 230 taxa are considered endemic (A. Tye, personal communication; Adsersen, 1989; Hamann, 1991; Porter, 1983). Although several endemic plant species exist within the Galápagos, only seven plant genera (Darwiniothamnus, Lecocarpus, Macraea and Scalesia in the Asteraceae, Brachycereus and Jasminocereus in the Cactaceae and Sicyocaulis in the Curcurbitaceae) are endemic to the entire archipelago. When reviewing the percentage of endemic plant taxa across island groups in the Pacific Ocean, endemism in the Galápagos Islands appears to be quite low in comparison with that of other Pacific island chains. For example, Hawaii's percentage of endemics at the species level is estimated at around 
$94.4 \%$, whereas that of the Galápagos is only thought to be around $37-43 \%$ (Porter, 1979).

At this point, one may wonder just how vulnerable are the endemic plant taxa of the Galápagos? In order to assess the conservation status for any plant taxon it is important to estimate its population size, geographical range, and evidence of population decline (IUCN, 2000). An example of such an estimation was discussed by Adsersen (1989), who noted that endemic plants throughout the world appear to be more vulnerable to the impacts of man than other native plants, a notion that is readily supported by his estimation of rarity in the Galápagos Islands. Adsersen (1989) found that $31 \%$ of the endemic plant species in the Galápagos were considered to be "rare" in accordance with the IUCN guidelines, and only $38 \%$ of those live in stable populations. This is in direct comparison with the native flora of the archipelago where only $20 \%$ are considered to be rare and upwards of 55\% were growing in stable stands (Adsersen, 1989). Because small and/or isolated populations of any plant species are typically prone to genetic drift, rarity itself may lead to speciation (and in some instances extinction), which is one of the prime factors leading to the evolution of new plant taxa within the archipelago.

It has been stated that if the Galápagos Islands are indeed 3-5 million years old, then one introduction every 7,300-12,100 years would account for the presence of the endemics and natives in the Galápagos Islands (Porter, 1983). It is well known that the flora of the Galápagos is very closely related to that of tropical and subtropical America (e.g. Svenson 1946), where $87 \%$ of the endemics and $97 \%$ of the non-endemic indigenous species are considered to be descendants of either widespread tropical species 
or are otherwise restricted to the South American mainland nearest the archipelago (Porter, 1983).

Indeed, Porter (1983) has stated that many of the plants of lowland Galápagos have been suggested to be closely related to those of the semi-desert area bordering the Gulf of Guayaquil in southern Ecuador and northern Peru. Most scientists familiar with the flora of the Galápagos Islands attribute different vectors of long-distance dispersal to bringing the current diversity of species to the archipelago, including wind and air currents, oceanic drift and dispersal brought upon by birds (Adsersen, 1991; Porter, 1983; Hamann, 1991, Perry et al. 1984, van der Werff, 1977). All of these vectors, along with various founder events and the steady adaptation and radiation discussed above, act upon the continental species upon arrival and may be responsible for the current diversity of disharmonic endemic species within the archipelago.

\section{Review of the Asteraceae within the Galápagos Islands - origin, history and modes of dispersal:}

\section{i. Introduction into the Asteraceae}

The Asteraceae comprise the largest family of flowering plants in the world consisting of 1535 genera and approximately 23,000 species (Bremer, 1994). The family is distributed worldwide but is most abundant in the southwestern United States and Mexico, southern Brazil, along the Andes mountains of South America, in the Mediterranean area, in southwestern and central Asia, South Africa, and Australia (Bremer, 1994). The family's geographic origin is thought to be in northern South America (Raven and Axelrod, 1974, Turner, 1977) as several of the earliest lineages of Asteraceae (i.e. Barnadesioideae) are found in South America. Another theory (Nur and 
Ben-Avraham, 1981, Humphries and Parenti, 1986) states that the possible origin of the Asteraceae is linked to the geological history of the Pacific basin. However, plate tectonics of the Pacific are complicated and involve a number of possible means for traversing the Pacific, including ancient slowly moving island areas such as the Hawaiian and Galápagos Islands (Wilson and Hey, 1995). Turner (1977) stated that it is possible the family originated in the mid-Cretaceous, which would be early enough for it to be distributed around the world as a result of plate tectonics. That theory, however, contradicts the one by Raven and Axelrod (1974), who thought that the family originated in the mid-Oligocene and felt that the migrations of the Asteraceae must be seen "in the light of present geography."

It is possible that the Asteraceae are older than the known fossil record indicates, but no direct evidence exists that proves its members were present in the Cretaceous. Another hypothesis by Bremer (1994) suggests that the family split from their present sister group in the mid-Tertiary. Although Pacific history may have influenced the distribution of the Asteraceae, the separation of the major continents of Gondwanaland was probably too early of an event to affect the distribution of the family (Bremer, 1993 $a, b)$.

\section{ii. Asteraceae in the Galápagos Islands}

Although several global floristic studies have been done for this family, no one has published the distribution of Asteraceae solely in terms of their presence on oceanic islands, and what is known about the family in the Galápagos Islands in particular, is fragmentary. The Asteraceae are the second largest family within the Galápagos Islands, consisting of 31 genera, four of which are considered to be endemic to the archipelago 
(Wiggens and Porter, 1971). In addition, although fifteen of these thirty-one genera are native and widespread with relative abundance throughout the Galápagos Islands, Lawesson (1990) has stated that in terms of their conservation status, the Asteraceae appear to be the family with the most taxa in a critical state within the Galápagos Islands. Evidence of this can be found in Tables 2.3, 2.4 and 2.5, which list all of the Galápagos taxa that are in a vulnerable state (VU), in danger of extinction (EN) or in critical danger of extinction (CR), respectively, according to the 2000 criteria of IUCN (Tye, 2000).

Of the four genera from the Asteraceae considered to be endemic to the Galápagos, three (Scalesia, Lecocarpus and Darwiniothamnus) paint a remarkably good picture of adaptive radiation within the archipelago; something that is rather uncommon within the islands. Tye and Callebaut (2002), stated that phyletic evolution is far more frequent in the archipelago than radiative evolution, as only 11 families and 19 genera have radiated into groups of 3 or more (up to 19) endemic taxa (see Table 2.2). The best example of adaptive radiation in the flora of the Galápagos, often considered to be on par with that of the Galápagos finches, is found in the woody endemic genus Scalesia (Eliasson, 1984; Hamann and Wium-Andersen, 1986; Adsersen, 1990; Porter, 1979).

\section{Scalesia:}

Scalesia, is a member of the tribe Heliantheae (subtribe Helianthinae) that comprises 15 species and as many as 21 taxa (Eliasson, 1974; Hamann \& WiumAndersen, 1986), although additional specific and sub-specific taxa may still need to be described (Lawesson \& Adsersen, 1987). Most members of this genus are found in the relatively dry lowlands of the archipelago, however this genus also contains three species of trees that occur in the highlands of the larger islands (Lawesson, 1990). Several 
scientists have focused on the woody Composites of the Galápagos (Harling, 1969; Cronquist, 1970 and 1971; Eliasson, 1972 and 1974; Carlquist, 1974; Hamann and Wium-Andersen, 1986), and a vast majority of the literature points to the overt woodiness in both Scalesia and Darwiniothamnus. However, it is not specifically known if the formation of woodiness on islands is derived secondarily, as was suggested by Carlquist (1974), or if it represents a primitive feature of continental floras that was carried over to oceanic islands via dispersal events. The lowland or coastal habitats of Scalesia are areas where several of the species are considered to have evolved, although most of the species remain in relatively small and geographically restricted populations (see Appendix $1 \mathrm{a} \& \mathrm{~b}$ for individual species distributions).

The taxonomy of the genus Scalesia is currently fairly stable, and there have not been many discrepancies over the taxonomic changes throughout the years (Harling, 1962; Wiggens and Porter, 1971; Schilling, 1994). At first glance the genus appears to be monophyletic based on the presence of trifid pales, gummy resin, and a tetraploid chromosome number of $2 \mathrm{n}=68$ in all species (Eliasson, 1974; Schilling et al., 1994), however this has never been tested by rigorous phylogenetic methods. The only extensive molecular work that has been performed on the genus is by Shilling et al. (1994) who used cpDNA restriction site data to compare Scalesia to potential sister groups within the subtribe Helianthinae. In specific, they found that Pappobolus was Scalesia's most likely sister group, even though it was formerly considered to be most closely related to Andean species of Helianthus and Viguiera, with which it shares the basic chromosome number of $x=17$ (Porter, 1979). Although there is significant morphological variation within Pappobolus, both Scalesia and Pappobolus are similar in 
that both genera include shrubs or small trees and both contain considerable variation in the features of the pappus (Schilling, 1994.)

The original introduction of Scalesia to the Galápagos was most likely by birds. It has been suggested that the ancestor of Scalesia first colonized the arid lowlands of a single island, which was then followed by adaptation to moister sites and to other islands (Carlquist, 1966). Currently, S. pendunculata occurs on the islands of Santa Cruz, Santíago, Floreana and San Cristóbal; $S$. cordata is restricted to Isabela south of Isthmus Perry, and S. microcephala can be found on Fernandina and the volcanoes north of Isthmus Perry on Isabela (Eliasson, 1984). A fourth and fifth species, S. atractyloides and $S$. darwinii, are considered in critical condition as only 80 and 500 trees are left in the archipelago, respectively (Williams, 1998). During the process of this adaptation to different island habitats, not only did the leaves of these plants become markedly different from each other in shape and size, but the plant heights also began to range from small shrubs to tall trees reaching upwards of 15 meters. Because this genus is one of the few Galápagos plant genera to include trees, its forest stands have acquired their own ecological zone, known throughout the Galápagos as the "Scalesia Zone."

\section{Lecocarpus:}

Until recently, Darwiniothamnus and Lecocarpus have also been noted for their successful adaptive radiation within the Galápagos Islands (Adsersen, 1980), however the taxonomic status of the former should be reconsidered, as is discussed in detail in Chapter 4. Lecocarpus, on the other hand, is a well-defined, distinct genus within the tribe Heliantheae with three currently recognized species, $L$. darwinii Adsersen, $L$. lecocarpoides (Robins. \& Greenm.) Cronq. \& Stuessy, and L. pinnatifidus Decne.; all of 
which are woody shrubs and considered to be threatened. Lecocarpus darwinii is only found on the island of San Cristóbal, L. lecocarpoides is only on Espanola and surrounding islets, and L. pinnatifidus only inhabits the island of Floreana (Adsersen, 1980). Although each species occupies a different island, they all prefer the arid lowlands of each island, which seems to promote the morphological uniformity among its species. In specific, all of species are shrub-like, 1-1.5 meters in height, with opposite, deeply pinnately dissected leaves and yellow flowers.

Although two species of Lecocarpus have been referred to the related genus Acanthospermum (Adsersen, 1980), each of the three species are closely allied and the general unity of the group has been supported by several different authors within Wiggins and Porter's (1971) flora of the archipelago. It is generally believed that the genus is most likely related to Acanthospermum and Melampodium, both of which contain a number of tropical American species. Although the exact sister relationship is unclear, chromosome counts and phylogenetic studies have not been performed on this genus to suggest otherwise (Stuessy, 1970; Eliasson, 1971).

\section{Macraea:}

The third endemic Composite genus in the Galápagos, Macraea, is also a member of the tribe Heliantheae and was named after James Macrae, who first collected this plant on the island of Isabela during a visit to the archipelago in 1825. Macraea is a shrub about 2.5 meters tall, with numerous slender branches and a chromosome number of $2 n=28$ (Eliasson, 1984). The opposite leaves are simple, linear, and very narrow, and give rise to the species' name, $M$. laricifolia, which alludes to the clusters of narrow leaves similar to those of the conifer genus Larix (McMullen, 1999). The flowers of 
Macraea are tiny and yellow with the disc flowers more prevalent than the ray flowers. This genus is currently considered to be monotypic with its only species, M. laricifolia, found on the islands of Fernandina, Floreana, Isabela, Pinta, Rabida, San Cristóbal, Santa Cruz and Santíago.

Harling (1962) stated that the greatest affinities to Macraea are most likely found in Wedelia, particularly among the American species of this genus, yet its origin is currently unknown. It is generally thought that adaptive radiation has not occurred in Macraea, nor in two other endemic genera of the Galápagos, Brachycereus and Sicyocaulis (Wiggens and Porter, 1971); however I and other botanists of the Charles Darwin Research Station have seen Macraea with several different morphological types at varying locations. The slight, yet obvious, morphological variation that exists within this genus thus warrants an in-depth morphological analysis across the entire archipelago.

The fouth and final endemic member of the Asteraceae in the Galápagos, Darwiniothamnus, will be covered in the next two chapters of this thesis. In addition, a comprehensive list of the introduced, native and endemic members of the Asteraceae in the Galápagos Islands is also included in Appendix $1 \mathrm{a} \& \mathrm{~b}$. This list is primarily adapted from Duncan Porter's chapter on Endemism and Evolution in Galápagos Islands Vascular Plants (1979) and his checklist of the vascular plant of the Galápagos Islands (1983). A few additions and revisions have been made to the list where new data has been made available since the publication of Porter's papers, however the list is not entirely complete for introduced species, as many more introduced Asteraceae have been discovered in the Galápagos in recent years. 
From the list in Appedix 1a one can readily note that the most widespread endemic species from the Asteraceae appear to be: Pectis subsquarrosa, which according to Porter (1983) is spread throughout at least 16 different islands, islets and rocks; Macraea laricifolia, which is spread throughout nine different islands and islets; Chrysanthellum pusillum, which is spread throughout seven islands and islets; Jaegeria gracilis, which is spread throughout six; Pectis tenuifolia, which is spread through out five; and Baccharis steetzii, Darwiniothamnus tenuifolius, Delilia repens, Encelia hispida, and Scalesia pedunculata which are all spread across four islands and/or islets. Again, by looking at Appendix 1a it is apparent that the Galápagos (at least at the time of Porter's 1979 and 1983 publications) contained 43 endemic taxa from the Asteraceae, comprising various genera, species, subspecies and varieties. The genus with the largest number of endemic taxa is by far Scalesia, followed by Darwiniothamnus, Delilia, Lecocarpus and Pectis. In addition to the endemic taxa, there are also 24 introduced weeds and 6 native species that represent the Asteraceae in the Galápagos. 
Table 2.1: History of collections in the Galápagos Islands from 1825-1930:

\begin{tabular}{|c|c|c|c|c|}
\hline Collector & Year & Total \# of plant taxa collected & New record for the Galápagos & New spp to science \\
\hline Douglas \& Scouler & 1825 & 18 & 18 & 18 \\
\hline Macrae & 1825 & 41 & 34 & 20 \\
\hline Cuming & 1829 & 9 & 4 & 4 \\
\hline Darwin & 1835 & 209 & 155 & 78 \\
\hline Petit-Thouars \& Neboux & 1838 & 5 & 3 & $?$ \\
\hline Edmonstone \& Goodridge & 1846 & 41 & 21 & $\dot{5}$ \\
\hline Wood & 1846 & 27 & 15 & $\mathbf{0}$ \\
\hline Andersson & 1852 & 69 & 8 & 2 \\
\hline Habel & 1869 & 69 & 8 & 2 \\
\hline Hill \& Steindacher & 1872 & 96 & 2 & 1 \\
\hline Wolf & 1875 & 7 & $?$ & $?$ \\
\hline Chierchia \& Marcacci & 1884 & 44 & 22 & 2 \\
\hline Lee & 1888 & 42 & 4 & $\mathbf{0}$ \\
\hline Agiz & 1891 & 41 & 1 & 0 \\
\hline Baur & 1891 & 385 & 37 & 37 \\
\hline $\begin{array}{l}\text { Snodgrass \& Heller } \\
\text { (Hopkins Expedition) }\end{array}$ & 1898-1899 & 949 & $?$ & $?$ \\
\hline $\begin{array}{l}\text { Stewart } \\
\text { (California Academy of } \\
\text { Sciences Expedition) }\end{array}$ & $1905-1906$ & 3000 & 615 & 10 \\
\hline Beebe, Rose \& Wheeler & 1923 & $\mathbf{n} / \mathbf{a}$ & $\mathbf{n} / \mathbf{a}$ & $\mathbf{n} / \mathbf{a}$ \\
\hline Wollebaek & 1924 & $\mathbf{n} / \mathbf{a}$ & 0 & 0 \\
\hline Riley & 1925 & $?$ & 3 & 1 \\
\hline Rorud & 1927 & 262 & 4 & 4 \\
\hline Svenson & 1930 & 300 & several & 5 \\
\hline
\end{tabular}

Table 2.2: Radiative groups in the Galápagos of at least 3 endemic taxa:

(Tye and Callebaut, 2002)

Family
Amaranthaceae
Asteraceae
Boraginaceae
Cactaceae
Euphorbiaceae

Molluginaceae

Piperaceae

Poaceae

Polygalaceae

Rubiaceae
Genus

Alternanthera Forssk.

Froelichia Monech

Darwiniothamnus Harling

Lecocarpus Decne.

Scalesia Arn. Ex Lindl.

Cordia

Tiquilia Pers.

Jasminocereus Britton \& Ros

Opuntia Mill.

Acalypha L.

Chamaesyce Raf.

Croton L.

Lamiaceae Salvia LO.

Mollugo L.

Peperomia Ruiz \& Pav.

Aristida L.

Paspalum L.

Polygala L.

Borreria G. Mey.
No. of taxa in group

8

5

4

3

19

3

3

3

14

6

9

4

3

9

4

4

3

5

6 
Table 2.3: Taxa in vulnerable status (VU) according to the 2000 criteria of IUCN (adapted from Tye, 2000)

\author{
Family \\ Monocotyledons \\ Orchidaceae \\ Poaceae \\ Poaceae \\ Dicotyledons \\ Amaranthaceae \\ Amaranthaceae \\ Amaranthaceae \\ Amaranthaceae \\ Amaranthaceae \\ Amaranthaceae \\ Amaranthaceae \\ Apiaceae \\ Asteraceae \\ Asteraceae \\ Asteraceae \\ Asteraceae \\ Asteraceae \\ Asteraceae \\ Asteraceae \\ Asteraceae \\ Boraginaceae \\ Boraginaceae \\ Boraginaceae \\ Boraginaceae \\ Boraginaceae \\ Burseraceae \\ Cactaceae \\ Cactaceae \\ Cactaceae \\ Caryophyllaceae \\ Convolvulaceae \\ Euphorbiaceae \\ Euphorbiaceae \\ Euphorbiaceae \\ Euphorbiaceae \\ Euphorbiaceae \\ Lamiaceae \\ Lamiaceae \\ Linaceae \\ Malvaceae \\ Malvaceae \\ Mimosaceae \\ Molluginaceae \\ Myrtaceae \\ Passifloraceae \\ Plantaginaceae \\ Polygalaceae

\section{Species} \\ Epidendrum spicatum Hook. f. \\ Paspalum redundans Chase \\ Trisetum howellii Hitchc. \\ Alternanthera flavicoma (Anderss.) Howell \\ Alternanthera galapagensis (Stewart) Howell \\ Alternanthera helleri (Robins.) Howell \\ Alternanthera snodgrassii (Robins.) Howell \\ Amaranthus furcatus Howell \\ Froelichia juncea Robins. \& Greenm. \\ Lithophila radicata (Hook.f.) Standl. \\ Hydrocotyle galapagensis Robins \\ Acmella darwinii (D.M. Porter) R.K. Jansen \\ Lecocarpus lecocarpoides Cronq. \& Stuessy \\ Scalesia aspera Anderss. \\ Scalesia baurii Robins. \& Greenm. \\ Scalesia gordilloi Hamann \& Andersen \\ Scalesia helleri Robins. \\ Scalesia incisa Hook. f. \\ Scalesia villosa Stewart \\ Cordia revoluta Hook.f. \\ Cordia scouleri Hook.f. \\ Heliotropium anderssonii Robins. \\ Tiquilia nesiotica (Howell) Richard. \\ Tournefortia rufo-sericea Hook.f. \\ Bursera malacophylla Robins. \\ Opuntia echios Howell \\ Opuntia helleri K. Schum. \\ Opuntia megasperma Howell \\ Drymaria monticola Howell \\ Ipomoea tubiflora Hook. f. \\ Acalypha abingdonii $\mathrm{O}$. Seberg \\ Acalypha baurii Robins. \& Greenm. \\ Acalypha wigginsii Webster \\ Chamaesyce abdita Burch \\ Chamaesyce nummularia (Hook.f.) Burch \\ Salvia prostrata Hook. f. \\ Salvia pseudoserotina Epling \\ Linum harlingii Eliass. \\ Fuertesimalva insularis (Kearney) Fryxell \\ Gossypium klotzschianum Anderss. \\ Acacia rorudiana Christoph. \\ Mollugo crockeri Howell \\ Psidium galapageium Hook.f. \\ Passiflora colinvauxii Wiggins \\ Plantago galapagensis Rahn \\ Polygala anderssonii Robins.
}


Cont.

Polygalaceae

Polygonaceae

Rubiaceae

Rubiaceae

Rubiaceae

Rubiaceae

Rubiaceae

Sapindaceae

Solanaceae

Solanaceae

Verbenaceae

Polygala sancti-georgii

Polygonum galapagense Caruel

Borreria dispersa Hook.f.

Borreria ericaefolia Hook.f.

Borreria linearifolia Hook.f.

Borreria perpusilla Hook.f.

Psychotria rufipes Hook.f.

Cardiospermum galapageium Robins. \& Greenm.

Iochroma ellipticum (Hook.f.) Hunz.

Jaltomata werffi D'Arcy

Verbenaceae

Lippia rosmarinifolia Anderss.

Verbena grisea Robins. \& Greenm. 
Table 2.4: Taxa in danger of extinction (EN) according to the 2000 criteria of IUCN (adapted from Tye, 2000)

\begin{tabular}{|c|c|}
\hline$\frac{\text { Family }}{\text { Pteridophyta }}$ & Species \\
\hline $\begin{array}{l}\text { Cyatheaceae } \\
\text { Monocotyledons }\end{array}$ & Cyathea weatherbyana (Morton) Morton \\
\hline $\begin{array}{l}\text { Cyperaceae } \\
\text { Dicotyledons }\end{array}$ & Cyperus grandifolius Anderss. \\
\hline$\overline{\text { Amaranthaceae }}$ & Alternanthera nesiotes Johnston \\
\hline Amaranthaceae & Pleuropetalum darwinii Hook.f. \\
\hline Asteraceae & Baccharis steetzii Anderss. \\
\hline Asteraceae & Darwiniothamnus alternifolius Lawesson \& Ads. \\
\hline Asteraceae & Encelia hispida Anderss. \\
\hline Asteraceae & Lecocarpus darwinii Adsersen \\
\hline Asteraceae & Lecocarpus pinnatifidus Decne. \\
\hline Asteraceae & Scalesia cordata Stewart \\
\hline Asteraceae & Scalesia stewartii Riley $\mathbf{E N}$ \\
\hline Asteraceae & Scalesia microcephala Robins. \\
\hline Asteraceae & Scalesia pedunculata Hook. f. \\
\hline Cactaceae & Opuntia galapageia Hensl. \\
\hline Cactaceae & Opuntia insularis Stewart \\
\hline Ericaceae & Pernettya howellii Sleumer \\
\hline Lamiaceae & Salvia insularum Epling \\
\hline Melastomataceae & Miconia robinsoniana Cogn. \\
\hline Rubiaceae & Galium galapagoense Wiggins \\
\hline Scrophulariaceae & Galvezia leucantha Wiggins \\
\hline Solanaceae & Capsicum galapagoense Heiser \& Smith \\
\hline
\end{tabular}

Table 2.5: Taxa in critical danger of extinction (CR) according to the 2000 criteria of IUCN (adapted from Tye, 2000)

Family

Monocotyledons

Orchidaceae

Dicotyledons

Amaranthaceae

Asteraceae

Asteraceae

Asteraceae

Cactaceae

Cucurbitaceae

Euphorbiaceae

Lamiaceae

Linaceae

Portulacaceae

Rubiaceae

Verbenaceae

\section{$\underline{\text { Species }}$}

Cyclopogon werffii Dodson

Lithophila subscaposa (Hook.f.) Standl.

Scalesia atractyloides Arn.

Scalesia divisa Anderss.

Scalesia retroflexa Hemsley

Opuntia saxicola Howell

Sicyocaulis pentagonus Wiggins

Euphorbia equisetiformis Stewart

Hyptis gymnocaulos Epling

Linum cratericola Eliass.

Calandrinia galapagosa St. John

Psychotria angustata Andersson

Lippia salicifolia Anderss. 
Figure 2.1: Vegetation Zones of a typical Galápagos Island:

(Adapted from a Teacher's Resource Guide to the Galápagos)

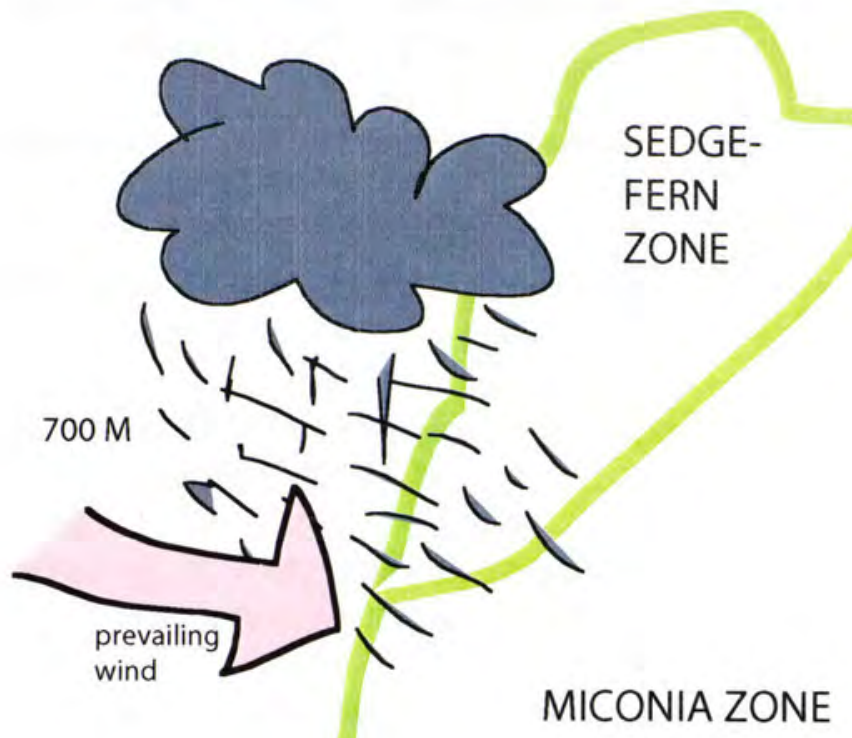

450M
SOUTH

$300 \mathrm{M}$

SCALESIA/TRANSITIONAL ZONE

NORTH

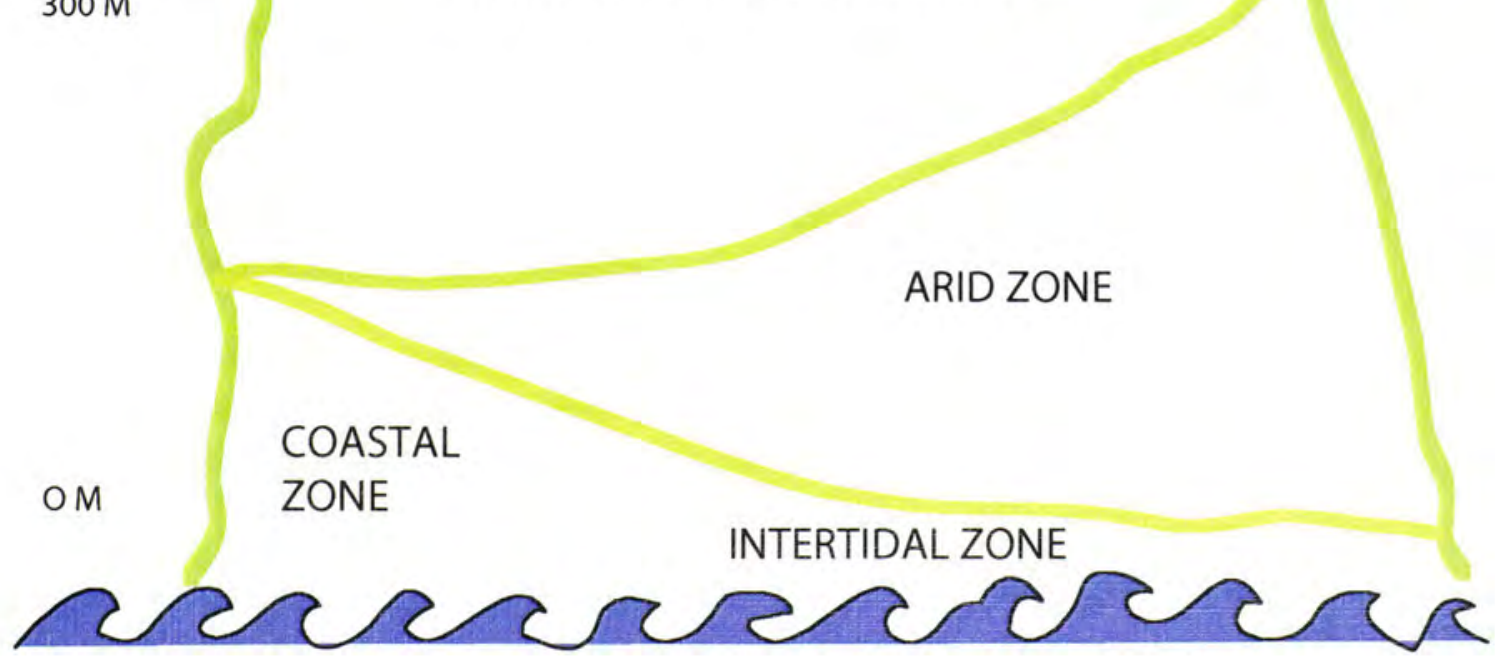




\section{REFERENCES}

Andersson, N.J. 1857. Om Galápagos Oarnes Vegetation. Kongl. Svensk. Vet. Akad. Handl. 1857: 1-114.

Adsersen, H. 1976a. Ombrophytum peruvianum found in the Galápagos Islands. Bot. Not. 129: $113-117$.

Adsersen, H. 1976b. New records of pteridophytes from the Galápagos Islands. Bot. Not. 129: 429-436.

Adsersen, H. 1980. Revision of the Galápagos endemic genus Lecocarpus (Asteraceae). Bot. Tid. 75: 63-76.

Adsersen, H. 1989. The rare plants of the Galápagos Islands and their conservation. Bio. Conserv. 47: 49-77.

Adsersen, H. 1990. Permanent vegetation quadrats in Galápagos. Monogr. Syst. Bot. Mo. Bot. Gard. 32: 149-152.

Adsersen, H. 1991. Evolution, extinction and conservation: examples from Galápagos flora. Evol. Trends Plts. 5: 9-18.

Banfield, et al. Geology of Isabela (Albemarle) Island, Archipelago de Colón (Galápagos). Bull. Geol. Soc. Amer. 67:215-234.

Baur, C. 1891. On the origin of the Galápagos Islands. Amer. Nat. 25: 217-229, 307-326.

Beebe, W. 1924. Galápagos World's End. Putnam. New York. p. xxi +443.

Bremer, K. 1993a. Ancestral areas - a cladistic reinterpretation of the center of origin concept. Sys. Bot. 41: 436-445.

Bremer, K. 1993b. Intercontinental relationships of African and South American Asteraceae - a cladistic biogeographic analysis. In Biological Relationships between Africa and South America. Ed. P. Goldblatt. New Havben: Yale University press.

Bremer, K. 1994. Asteraceae, Cladistics and Classification. Timber Press, Portland, Oregon.

Carlquist, S. 1966. The biota of long-distance dispersal. II The lost of dispersal in Pacific Compositae. Evolution. 20: 30-48. 
Carlquist, S. 1974. Island Biology. Columbia University Press, New York and London.

Christie, D. M. et al. 1992. Drowned islands downstream from the Galápagos hotspot imply extended speciation times. Nature $355: 246-248$

Christophersen, E. 1932. A collection of plants from the Galápagos. Nyt Mag. Naturvidensk. 70: 67-97.

Colvinaux, P. 1972. Climate and the Galápagos Islands. Nature 240:17-20.

Cox, A. 1983. Ages of the Galápagos. Pacific Division, AAAS. 11-23.

Cronquist, A. 1970. New combinations in the Compositae of the Galápagos Islands. Madrono 20: 255-256.

Cronquist, A. 1971. Compositae. In :Wiggins, I.R. and Porter, D. M. (eds.) Flora of the Galápagos Islands. Stanford University Press, Stanford, pp. 300-367.

Davis et al. 1995. Centres of plant diversity: a guide and strategy for their conservation. Volume 2: Asia, Australasia and the Pacific. WWF and IUCN, Cambridge.

Eliasson, U. 1971. Studies in Galápagos Plants X: The genus Lecocarpus Decaisne. Sv. Bot. Tidskr. 65: 245-277.

Eliasson, U. 1972. Studies in Galápagos Plants XIII: Three new floristic records and two supplementary remarks. Bot. Not. 125: 320-322.

Eliasson, U. 1974. Studies in Galápagos Plants XIV: The genus Scalesia. Opera Bot. 36: 1-117.

Eliasson, U. 1984. Native climax forests. In: Perry, R. (ed.), Key environments. Galápagos. Pergamon Press, Oxford. Pp. 101-114.

Hamann, O. 1974. Contributions too the Flora and Vegetation of the Galápagos Islands I: New floristic records from the archipelago. Bot. Not. 127: 245-251.

Hamann, O. 1984. Changes and threats to the vegetation. In Perry, R. (ed.), Key environments. Galápagos. Pergamon Press, Oxford. Pp. 115-131.

Hamann, O. and Wium-Andersen, S. 1986. Scalesia gordilloi $\mathrm{sp}$. Nov. (Asteraceae) from the Galápagos Islands, Ecuador. Nord. J. Bot. 691): 35-38.

Hamann, O. 1990. Research and management in the Galápagos: Some Botanical Considerations. Monogr. Syst. Bot. Miss. Bot. Gard. 32: 5-10. 
Hamann, O. 1991. Indigenous and alien plants in the Galápagos Islands: problems of conservation and development. In Heywood, V.H. and Wyse Jackson, P.S. (eds.), Tropical botanic gardens: their role in conservation and development. Academic Press, London. Pp. 169-192.

Harling, G. 1962. On some Compositae endemic to the Galápagos Islands. Acta Hort. Berg. 20: 63-120.

Hooker, J. D. 1847. On the Vegetation of the Galápagos Archipelago, as compared with that of some other Tropical Islands and of the Continent of America. Trans. Linn. Soc. 20: 235-262.

Howell, J. T. 1933a. The genus Mollugo in the Galápagos Islands. Proc. Cal. Acad. Sci. IV, 21: 13-23.

Howell, J. T. 1933b. The Cactaceae of the Galápagos Islands. Proc. Cal. Acad. Sci. IV, 21: 41-54.

Howell, J.T . 1933c. The Amaranthaceae of the Galápagos Islands. Proc. Cal. Acad. Sci. IV, 21:87-116.

Howell, J. T. 1934a. Cacti in the Galápagos Islands. J. Cact. Succ. 5; 515-518: 531-532.

Howell, J. T. 1934b. Concerning names of species of Cereus in the Galápagos Islands. J. Cact. Succ. 5: 585-586.

Howell, J. T. 1937. The plant genus Coldenia in the Galápagos Islands. Proc. Cal. Acad. Sci. IV, 22: 99-110.

Howell, J. T. 1941a. The genus Scalesia. Proc. Cal. Acad. Sci. IV; 22: 221-271.

Howell, J. T. 1941b. Hugh Cuming's visit to the Galápagos Islands. Llyodia 4: 291-292.

Howell, J. T. \& Porter, D.M. 1968. The plant genus Polygala in the Galápagos Islands. Proc. Cal. Acad. Sci. IV, 32: 581-586.

Humphries, C. J. and Parenti, L. R. 1986. Cladistic Biogeography. Oxfrord monographs on biogeography 2. Oxford: Clarendon Press.

Jackson, E. D. 1976. Linear volcanic chains on the Pacific Plate. In: Sutton et al. (eds) The Geophysics of the Pacific Ocean and Its Margin. Pp. 319-335. 
Jackson, M. 1993. Galápagos, a Natural History. Alberta, Canada: University of Calgary Press.

Keil, D. J. 1977. Chromosome studies in North and Central American species of Pectis L. (Compositae: Tageteae). Rhodora 79: 79-94.

Lawesson, J. D. 1986. Report on the most threatened endemic plants in the Galápagos, December 1986. Unpublished, housed in the CDRS library, Santa Cruz, Galápagos Islands.

Lawesson, J.E. and Adsersen, H. 1987. Notes on the endemic genus Darwiniothamnus Harling (Asteraceae, Astereae) from the Galápagos Islands. Op. Bot. 92:7-15.

Lawesson, J. 1990. Threatened plant species and priority plant conservation sites in the Galápagos Islands. Monogr. Syst. Bot. Missouri Bot. Gard. 32: 153-167.

McMullen, Conley. 1999. Flowering Plants of the Galápagos Islands. Cornell: Cornell University Press.

Nur, A. and Ben-Avraham, Z. 1981. Lost Pacifica continent, a mobilistic speculation. In Vicariance Biogeography. New York: Columbia Univeristy Press. 341-358.

Ono, M. 1967a. Chromosome numbers of Scalesia (Compositae), an endemic genus of the Galápagos Islands. J. Jap. Bot. 42: 353-360.

Ono, M. 1967b. The systematic position of Scalesia from the viewpoint of chromosome numbers. Noticias de Galápagos 9/10: 16-17.

Ono, M. 1971. Chromosome numbers of Scalesia (Compositae), an endemic genus of the Galápagos Islands (2). J. Jap. Bot. 46: 327-334.

Percy, R. G. and Wendel, J. F. 1990. Allozyme evidence for the origin and diversification of Gossypium barbadense L. Theoret. App. Gen. 79: 529-554.

Perry, R. 1984. The Islands and Their History. In Perry, R. (ed.), Key environments. Galápagos . Pergamon press, Oxford. 101-114.

Porter, D. M. 1976. Geography and dispersal of Galápagos Islands vascular plants. Nat. Lond. 264: 745-746.

Porter, D.M. 1979. Endemism and evolution in Galápagos Islands vascular plants. In: Plants and Islands. D. Bramwell, ed. pp. 225-226. 
Porter, D. M. 1983. Vascular plants of the Galápagos: origin and dispersal. In: Patterns of Evolution in Galápagos Organisms. Eds. R. J. Bowmann, M. Berson \& A. E. Leviton. Pacific Division, AAAS. San Francisco: pp. 33-96.

Porter, D.M. 1984. Endemism and evolution in terrestrial plants. In Perry, R. (ed.), Key environments,. Galápagos. Pergamon Press, Oxford: pp. 85-99.

Raven, P. H. and Axelrod, D. I. 1974. Angiosperm biogeography and past continental movements. Annals of the Missouri Botanical Garden 61: 539-673.

Riley, L. A. 1925. Critical notes on Galápagos Plants. Kew Bulletin, 1925: 216-231.

Robinson, B. L. 1902. Flora of the Galápagos Islands. Proc. Amer. Acad. 38:78-270.

Robinson, B. L. and Greenman, J.M.. 1895. On the flora of the Galápagos Islands as shown by the collections of Dr. Baur. American Journal of Science 50: 135-149.

Schilling, E. et al. 1994. Evidence from chloroplast DNA restriction site analysis on the relationships of Scalesia (Asteraceae: Heliantheae). American Journal of Botany 81(2): 248-254.

Schofield, E. 1973. Annotated Bibliography of Galápagos Botany, Ann. Miss. Bot. Garden 60: 461-477.

Steussy, T. F. 1970. The genus Acanthospermum (Compositae-HeliantheaeMelampodinae): Taxonomic changes and generic affinities. Rhodora 72: 106-109.

Stuessy, T. F. 1975. Delilia (Compositae). Flora of Panama, Part IX, Family 184. Ann. Mo. Bot. Gard. 62: 1057-1058.

Stewart, A. 1911. Expedition of the California Academy of Sciences to the Galápagos Islands 1905-1906. A botanical survey of the Galápagos Islands. California Academy Press. San Francisco, California.

Stewart, A. 1911. A botanical survey of the Galápagos Islands. Proceedings of the California Academy of Sciences. IV, 1: 7-288.

Svenson, H.K. 1935. Plants of the Astor Expedition, 1930 (Galápagos and Cocos Islands). American Journal of Botany 22: 208-277.

Svenson, H. 1946. Vegetation of the coast of Ecuador and Peru and its relation to the Galápagos Islands. American Journal of Botany. 33: 394-426 
Turner, B. L. 1977. Fossil history and geography. In The Biology and Chemistry of the Compositae, vol 1. Eds. V. H. Heywood, J.B. Harborne, and B.L. Turner. London: Academic Press. 21-39.

Tye, A. 2002. Revision of the threat status of the endemic flora of Galapagos. Galapagos Report 6.

Tye, A. and Callebaut, J. 2002. Las plantas endémicas de Galápagos: diversidad, estado y amenazas. In: La Botánica en al Nuevo Milenio: Memorias del tercer congreso Ecuatoriano de Botánica. Alina Freire Fierrro y David A. Neill, eds. Funbotanica. Quito, Ecuador.

van der Werff, H. 1977. Vascular plants from the Galápagos Islands: new records and taxonomic notes. Bot. Not. 130: 89-100.

van der Werff, H. 1946. The vegetation of the Galápagos Islands. Akenman \& Ochtman. Zierikzee, Denmark.

Weber, D. 1973. Deux orchidacées nouvelles pour la flore des iles Galápagos. Bul. Soc. Neuchatel. Sci. Nat. 96: 17-32.

Whittaker, R. 1998. Island Biogeography: Ecology, Evolution and Conservation. Oxford University Press, New York.

Wiggins, I. 1975. Ranunculus flagelliformis discovered in the Galápagos Islands. Madroño. 23: 62-64.

Wiggins, I. and Porter, D. (1971) Flora of the Galápagos Islands. Stanford University Press. Stanford, CA.

Williams, H. 1966. Geology of the Galápagos Islands Plants in Galápagos Islands: proceedings of the symposia of the Galápagos International Scientific Project. Ed. R. Bowman. University of California Press. Berkely, California. 4654.

Wilson, D. and Hey, R. 1995. History of rift propagation and magnetization intensity for the Cocos-Nazca spreading center. J. Geophysical Res. 100(B7): 10,041-10, 056.

Wolf, T. Ein Besuch der Galápagos Inseln, mit drei Kartchen. Samml. Vortr deutsche Volk. 1;259-302. 


\section{CHAPTER 3: FIELD OBSERVATIONS AND ECOLOGICAL NOTES}

\section{Distribution and habitat of Darwiniothamnus:}

Most species of Darwiniothamnus, as the genus is currently recognized, range from woodlands to open lava beds, and from rocky shorelines to the rims and sometimes inside of many volcano craters. Historically the genus has been known to inhabit the four largest islands of the Galápagos (Fernandina, Isabela, Santíago, and Santa Cruz), and to occur on three of the smaller islands, namely Pinta, Pinzón, and Floreana. The geographical range of the three species overlap in only one small region on the southern slopes of Volcán Sierra Negra, located on the southeast tip of the island of Isabela. It is currently unknown to what extent the three species form hybrid swarms at this location, as has been reported for several congeneric species of most oceanic islands (Baldwin et al., 1998). Preliminary field observations suggest, however, that some degree of hybridization does exist.

Natural hybridization is known to occur throughout the world in areas of sympatry and is a major factor influencing the evolution of plants on islands (Borgen 1976, Brochmann 1984). In addition, hybridization has long been considered to be an important factor in the evolution of certain clades of Asteraceae (e.g. in those of Argyranthemum and the Silverswords) both in Macaronesia and the Hawaiian islands, respectively (Francisco-Ortega, et al., 1997, Baldwin, 1992). Because introgression is hypothesized to generate genetic diversity in otherwise uniform plants, it could have been a way in which the ancestors of Darwiniothamnus that were once located on relatively small islands and/or areas were able to increase their heterogeneity. 
Visible, but well separated from Isabela, are three additional islands, Fernandina, Santíago and Santa Cruz; each with an area exceeding $500 \mathrm{sq} \mathrm{km}$. Two species of Darwiniothamnus with several apparent varieties inhabit these islands and a recognized subspecies of $D$. tenuifolius, ssp. santacruzianus, grows exclusively in very small populations at the upper elevations of the island of Santa Cruz near Cerro Crocker. Beyond Santa Cruz in the far east lies a fifth major island, San Cristóbal, which historically has never been known to contain any members of Darwiniothamnus. The rest of the smaller islands, in descending order of size, are: Floreana, Marchena, Española, Pinta, Baltra, Santa Fe, Pinzón and Genovesa. Previously, Darwiniothamnus was known only to inhabit three of these smaller islands, Pinta, Pinzón, and Floreana (Wiggens and Porter, 1971). However, after having searched quite extensively on the island of Pinzón and not having found any members of the genus, it appears that the genus has been extirpated from the island, perhaps as the result of foraging by a now extinct feral goat population.

An island-by-island account of the species I found at each collection site throughout the archipelago is listed in Appendix 2. My first trip covered all areas on the island of Santa Cruz where Darwiniothamnus tenuifolius ssp. santacruzianus was known to exist. My second trip covered the island of Pinzon, all the major coves and northern volcanoes of Isabela, and included two stops on the island of Fernandina. My third trip was a return to Isabela, to the volcanoes of Sierra Negra, Cerro Azul, and surrounding areas. And finally, my fourth collecting trip was to Santiago, Marchena and Pinta (a map of all these areas and the species distributions can be found in Figure 3.1). 
Appendix 2 also contains remarks on the hypothesized stability of each population of Darwiniothamnus I encountered on the different islands, and if I noticed any unusual forms which might be examined for new specific or subspecific recognition in the future (a general consensus of my findings can be found in the concluding remarks section of this paper and is discussed further in the Chapter 4 as well). Special attention is also paid to leaf form and degree of hairiness, as these are some of the major characteristics by which the genus is divided. Additional information on the factors directly threatening the stability of individual populations is also discussed in more detail below.

\section{Biological threats on extant populations of Darwiniothamnus:}

The three most significant biological threats to the native and endemic flora of the Galápagos Islands are introduced animals, aggressive alien plants, and agricultural encroachment (e.g. Hamann, 1984, 1991; Hoeck, 1984; Brockie et al., 1988; Adsersen, 1989; Loope, Hamann and Stone, 1988; Scofield, 1989). No less important, however, are several additional biological threats including: habitat fragmentation, over-exploitation of native woody species, increasing pressure from resident human populations due to the sharp increase in immigration to the islands, increasing tourist pressure, and man-made fires (Davis et al., 1995).

Currently there are approximately 600 exotic plant species in the archipelago, of which 250 are considered to be naturalized introduced weeds and 37 are considered to be disruptive invasives (see Tables 3.1 and 3.2) (Tye, 2001; Tye, Soria and Gardener, 2002). These numbers, however, continue to grow each year as a result of the increase in traffic to and among the islands over the past 30 years. Hamann $(1984,1991)$ has stated that the 
most dangerous invasives directly affecting the native vegetation are most likely Psidium guajava (Myrtaceae), Cinchona succirubra (Rubiaceae), Lantana camara (Verbenaceae), Rubus spp. (Rosaceae), Pennisetum purpureum (Poaceae), and perhaps Passiflora edulis (Passifloraceae) and P. ligularis. These plant species not only compete directly with endemics and natives for space and resources, but also may be responsible for the introduction of other pest organisms, such as Icerya purchasi, the cottony cushion scale insect.

Icerya purchasi is a known predator of many native and endemic plant species of the Galápagos including Cordia lutea (Boraginaceae), Hibiscus tiliaceus (Malvaceae), Laguncularia racemosa (Combretaceae), Merremia aegyptica (Convolvulaceae), Parkinsonia aculeata (Fabaceae), Piscidia carthagenesis (Fabaceae), Darwiniothamnus tenuifolius (including all ssp.), and D. lancifolius (including all ssp) (McMullen, 1999). Once infested by I. purchasi, all of these plant species and many others die rapidly as a direct result of the insect feeding on the plants' xylem and phloem.

The origin of this pest is thought to be California, where it was introduced, probably from Australia, in the mid 1800s (McMullen, 1999). Upon arrival in South America, I. purchasi was introduced into the Galápagos almost certainly from mainland Ecuador on imported citrus (Tye, personal communication). This insect has no known natural enemies in the Galápagos, but California's valuable citrus population was spared by using a species of lady bug (Rodolia cardinalis) and cryptochetum fly (Cryptochetum iceryae) in order to control the spread of the scale insect. Although the introduction of exotic insects to the Galápagos for biological control is controversial due to possible unforeseen detrimental effects (McMullen, 1999), controlled studies at the CDRS using 
Rodolia cardinalis suggested that the ladybug would not adversely affect native scale insects, their predators, nor bird species that might eat it. It was therefore released as the first biological control attempt in the Galápagos, in January of 2002.

In addition to invasive plant and insect species, several introduced animal species have also caused severe and possibly irreversible effects on the native flora and fauna of the Galápagos Islands. Lawesson (1990), has given a number of examples of endemic plant genera that suffer from the introduction of both alien plants and animals, and one specific example is that of Lecocarpus pinnatifidus (Asteraceae). This species inhabits the arid zone and humid highlands of Floreana, and has a range that has been steadily decreasing in recent years, possibly due to the invasion of introduced plants such as Lantana camara L. (Cruz et al., 1986; Lawesson \& Ortiz, 1990). Although L. pinnatifidus was still known from some localities at the time Lawesson wrote his paper, he feared it could quickly become extinct due to the increasing goat population on Floreana, which was at about 10,000 in 1987 (Lawesson, 1990). However, since the late 1980 's better goat control has been used on this island and the species now appears to be somewhat stable (Tye, personal communication).

Another related example is that of two arid zone taxa of Scalesia (S. atractyloides, var. atractyloides and var. darwinii; Asteraceae), which are also in extreme danger of extinction due to the depletion by feral goats (McMullen, 1999). Feral goats, pigs and cattle were once introduced to many islands of the archipelago several years ago as a sustainable food source for both local fishermen and residents of the archipelago. However, the impact these large feral animals have had on the local flora of the archipelago is considerable; not only do these animals feed on several different plant 
species (including most species of Darwiniothamnus), but they also trample and wear paths through the vegetation. Because these once small ruminant populations have now reproduced to such large proportions, several eradication measures are currently underway to remove them completely from as many islands as possible.

\section{Soil observations and analyses:}

\section{i. Introduction:}

During my field research throughout the islands, it became evident that there was no individual soil type that was preferred by all members of Darwiniothamnus. The type of volcanism found in the Galápagos is such that the upper slopes of the islands have a different soil type than the lower ones, due to differences in parent rock (van der Werff, 1977). Because members of this genus can be found at multiple elevations and in various climatic zones, I decided to investigate what some of the limiting nutrients might be for the successful introduction of this genus into new ecological niches. I therefore collected soil samples across all the islands that I visited, both at locations where different taxa of Darwiniothamnus were found growing and in places where they were not. My initial hypothesis is that there is not an individual nutrient that currently acts as the limiting factor for the successful growth of Darwiniothamnus, however a combination of missing nutrients could be enough to prevent this genus from colonizing new, or previously uninhabited, areas of the archipelago.

\section{ii. Soil collection methodology}

Twenty-nine soil samples were collected in $150 \mathrm{ml}$ plastic "Whirl-pak" bags. One combined sample was taken for each collection site in most cases, each weighing approximately 100 grams. In some instances we were able to sample different root zones 
and have them analyzed separately. Typically, after removal of the top organic layer, soil samples were obtained from a depth ranging between 5 and 35 centimeters. A few of the samples were located near juvenile plants growing in areas with almost no top soil, and where the species of Darwinothamus appeared to be a pioneering plant growing in volcanic sump holes protected from the wind.

Once the samples were collected, GPS locations and photos of the surrounding vegetation were taken at their resident soils and correlated. With the permission of the CDRS, the samples were then exported and sent to the Growers Testing Service (Visalia, California) where the analyses were run. All soil samples were autoclaved prior to analysis, as required by the USDA, and a list of all the analyses run, including their methodology can be found in Table 3.3.

Upon receiving the results of the soil analyses, a Mann-Whitney U test (with 2tailed $p$ values of $\leq 0.05$ ) was run on each taxon across all of the analyses performed to see if any of the soil characters were significantly correlated with the presence or absence of species of Darwiniothamnus (see Table 3.6 for all of the significant results).

\section{iii. Results}

As previously mentioned, the soils collected for analysis were chemically analyzed for elements of agriculture suitability. The results of each test performed on each individual sample are located in Appendix 3 and a description of the collection sites and qualitative soil descriptions are located in Table 3.4. The means and average for each analysis run in the saturation extract, nutrients by dry soil estimate and the trace metals, are also cross referenced in Table 3.5 with the geographical locations listed and the species of Darwiniothamnus present at each site. In addition to these tables, 
Appendix 3 contains general information on each of the analyses run, in terms of their ecological importance, and briefly describes some qualitative correlations between each sample site. These findings are briefly summarized below, followed by the significant results of the study.

Soil $\mathrm{pH}$ levels are known to have a direct influence over the availability of both macro and micronutrients and their uptake by plants (Brady, 1990). From all of the sites where soil was collected, the highest $\mathrm{pH}$ values of 8.6 and 8.5 were found at both locations collected near the base of Volcan Ecuador (soil sample numbers 7 and 16, respectively). The first location, which was quite near the shore, contained a sparse population of D. lancifolius ssp. glandulosus. The second location, however, was bare of any species of the genus. Thus, highly basic soils could be a reason for the absence of Darwiniothamnus at this location, however further analyses should be run before any strict hypothesis is developed.

Electrical conductivity (Ece) is an estimate of the relative amount of salt in a given area. Generally speaking, Ece values of less than 2.0 indicate no salt excess, where as values of 2.0-4.0 may restrict the growth of certain agricultural crops. Ece values of 4.0-8.0 are known to restrict the growth of many crops, and locations that contain Ece values of 8.0-16 and above are known to house only very salt tolerant plants (Rivers, 2002). In general, all of the Ece values for the sites collected in the Galápagos were below 2.0 (see table 4.1), except at Cartago Bay (soil sample numbers 1-4). This location varied from 2.0-5.9 with an average Ece of 4.15. This is expected, however, as the location is located very close to the ocean and receives both spray and wind from the seaside. This location was also home to a robust population of $D$. tenuifolius, which 
suggests that soils with either a high or low salt content are not a limiting factor for the survival of Darwiniothamnus.

Brady (1990) listed six nutrient elements, N, P, K, Ca, Mg, and S, that are essential for the growth of plants. All of these elements are provided to plants in the form of soil solids and are used in relatively large amounts by most plant species. Due to the relatively small sample size of soil collected at each location, only $\mathrm{Ca}, \mathrm{Mg}, \mathrm{Ca}+\mathrm{Mg}$, and $\mathrm{P}$ were tested from the saturation extract, and $\mathrm{K}$ and $\mathrm{NO}_{3}-\mathrm{N}$ were both tested from the saturation extract and as a dry soil estimate.

The highest levels of $\mathrm{Ca}$ and $\mathrm{Mg}$ were found on the islands of Fernandina, near Roca Tarzan (15.27 meq), and at Cartago Bay (17.93 meq), respectively; and the lowest levels for both (0.4 and $0.28 \mathrm{meq})$ were found at Volcan Ecuador. Sumner (2000) has stated that environments containing considerable amounts of $\mathrm{Ca}$ and $\mathrm{Mg}$ are often the result of other components in the soil such as limestone, fertilizers and animal manures. This could explain the high level of $\mathrm{Mg}$ at Cartago Bay where feral goats were known to exist for several years, however the same explanation cannot be used for the high level of $\mathrm{Ca}$ on the island of Fernandina, which is void of all animals except for birds. In any case, it could be that low levels of each of these two nutrients may inhibit the successful germination and subsequent growth of all species of Darwiniothamnus, as the site that produced the two lowest values of $\mathrm{Ca}$ and $\mathrm{Mg}$, Volcan Ecuador, was completely void of any members of this genus. However, additional evidence for another area besides this one site is needed before any concrete hypotheses can be made.

Rivers (2002) has stated that $\mathrm{NO}_{3}-\mathrm{N}$ values below $5 \mathrm{ppm}, \mathrm{P}$ values below $7 \mathrm{ppm}$ and $\mathrm{K}$ values below $80 \mathrm{ppm}$ are extremely low for most soil environments and could 
prevent the successful growth of many plant species. Nutrient dry soil estimates of all of each of these elements shows that the lowest level of $\mathrm{NO}_{3}-\mathrm{N}(1 \mathrm{ppm})$ was found at two locations: Volcan Ecuador (where no species of Darwiniothamnus were present) and on the southern coast of Santiago, near Cabo Nepean (where only a very few plants of Darwiniothamnus were found over a $3 \mathrm{~km}$ square radius). The lowest level of $\mathrm{P}$ ( $2 \mathrm{ppm})$, however, was found on the coast of Fernandina, where oddly the healthiest stand of $D$. lancifolius ssp. glandulosus throughout all of the islands was found. Finally, the lowest level of K (48 ppm) was also found on the southern coast of Santiago, near Cabo Nepean, where again, only a very few plants of Darwiniothamnus were found.

Brady (1990) also listed eight elements, or micronutrients, obtained from soil solids (Fe, B, Mo, $\mathrm{Mn}, \mathrm{Cu}, \mathrm{Zn}, \mathrm{Cl}, \mathrm{Co}$ ) that are used in relatively small amounts by most plants, but which are nonetheless essential for their proper growth. With the amount of soil collected, I was able to test for $\mathrm{Cl}, \mathrm{B}, \mathrm{Zn}, \mathrm{Mn}, \mathrm{Fe}$ and $\mathrm{Cu}$ from each location I visited within the Galápagos. Rivers (2002) has stated that while standard levels for Mn, Fe and $\mathrm{Cu}$ have not been well established, if any of the values fall below $2 \mathrm{ppm}, 5 \mathrm{ppm}$ and .1 ppm respectively, a possible deficiency could exist. Two of these three elements were below or close to below these limits $(\mathrm{Mn}=1.5 \mathrm{ppm}$ and $\mathrm{Cu}=0.4)$, and both were collected from Volcan Ecuador, where no species of Darwiniothamnus were found. Coincidently, this is also the site where the lowest level of $\mathrm{Zn}$ was found among all of the soil samples collected.

Although some interesting trends were readily detected from the raw soil data, as described above, additional significant results were also obtained using a Mann-Whitney $U$ test. This test was performed in order to investigate whether any of the soil characters 
were significantly correlated with the presence or absence of species of

Darwiniothamnus. The results for this test are located in Table 3.6 and it should be noted that while a brief summary of the potentially limiting factors is discussed below for each species, subspecies and variety of Darwiniothamnus; the results are based on limited data and thus ought to be treated only as preliminary data.

By looking at the results in Table 3.6, it appears that water could be the major limiting resource for successful growth of D. tenuifolius, a notion that is tenuously supported by the species' range across the archipelago. $\mathrm{Zn}(\mathrm{Z}=-1.5, \mathrm{p}=.037), \mathrm{Fe}(\mathrm{Z}=-$ 2.08, $\mathrm{p}=.038), \mathrm{Na}(\mathrm{Z}=-1.86, \mathrm{p}=.063)$ and organic matter $(\mathrm{Z}=-1.86, \mathrm{p}=.063)$ could also be the limiting factors for D. tenuifolius var. tomentosus, as the data appears to be supported by the fact that across all the sample sites, Pinta contained the highest amount of $\mathrm{Zn}$. In addition, this site also contained relatively high amounts of $\mathrm{Fe}, \mathrm{Na}$ and organic matter. Exchangeable $\mathrm{Na}(\mathrm{Z}=-2.08, \mathrm{p}=.038), \mathrm{pH}(\mathrm{Z}=-2.04, \mathrm{p}=.037)$ and $\mathrm{NO}_{4}-\mathrm{N}(\mathrm{Z}=-1.94$, $\mathrm{p}=.053$ ) may all represent the limiting factors for this successful growth of $D$. alternifolius, since this species is limited to two relatively small areas on the southern tip of Isabela. The same can be said for D. lancifolius ssp. glabriusculus, which could have the limiting factors of $\mathrm{Fe}(\mathrm{Z}=-2.77, \mathrm{p}=.006), \mathrm{pH}(\mathrm{Z}=-3.12, \mathrm{p}=.002)$ and Carbonate $(\mathrm{Z}=-$ $2.86, \mathrm{p}=.004$ ), as it also is only found on Volcan Sierra Negra which also had the lowest values for $\mathrm{pH}$ and carbonates, and the highest values of $\mathrm{Fe}$ (see table 3.5). It must be noted, however, that $D$. alternifolius and D. lancifolius ssp. glabriusculus may have always been restricted to Volcan Sierra Negra for another reason altogether.

Finally, by looking at the results from Table 3.6, Saturation $\%(Z=-3.16, p=.002)$, $\mathrm{Zn}(\mathrm{Z}=-1.84, \mathrm{p}=.066)$ and organic matter $(\mathrm{Z}=-2.00, \mathrm{p}=.045)$ could also be the limiting 
factors for D. lancifolius ssp. glandulosus, which is somewhat interesting as this species grows predominantly in non-lava areas where there's plenty of soil and several other species growing

In addition to these results, soil samples taken where there were no species of Darwiniothamnus present appear to be lacking in $\mathrm{Ca}(\mathrm{Z}=-1.93, \mathrm{p}=.053), \mathrm{Ca}+\mathrm{Mg}(\mathrm{Z}=-$ $2.01, \mathrm{p}=.045), \mathrm{NO}_{4}-\mathrm{N}(\mathrm{Z}=-1.94, \mathrm{p}=.053)$ and organic matter $(\mathrm{Z}=-2.00, \mathrm{p}=.045)$. These results are supported by the fact that when looking at the raw data across all 29 soil samples, the locations which had the lowest values for $\mathrm{Ca}, \mathrm{Ca}+\mathrm{Mg}$ and $\mathrm{NO} 4-\mathrm{N}$ are indeed where no species of Darwiniothamnus were found growing (see Table 3.5). It is therefore possible that these elements are the ultimate limiting factors for the successful introduction of Darwiniothamnus into previously uncolonized areas of the Galápagos Islands.

\section{iv. Discussion}

When considering the results of the soil analyses it appears evident that Volcan Ecuador is the one location that is void of several of the element and micronutrients necessary for the successful growth of most plants. In specific, the lowest levels for

Calcium (0.4 meq), Magnesium (0.28 meq), Nitrate-nitrogen (1 ppm), Manganese (1.4 ppm) and Copper (.4 ppm) were all found at the sample site from this location where no species of Darwiniothamnus were found growing. Brady (1990) has listed the following importance of each of these elements: Copper $(\mathrm{Cu})$ is involved in photosynthesis and respiration and in the use of iron, stimulates lignifcation of all plant cell walls; a deficiency in Boron (Bo) can decrease the rate of water absorption, root growth and translocation of sugars in plants; Manganese $(\mathrm{Mn})$ is essential for certain nitrogen 
transformations in microorganisms as well as in plants; both Zinc ( $\mathrm{Zn})$ and Manganese function in enzyme systems necessary for important reactions in plant metabolism; and both Copper and Iron (Fe) act as electron carriers in enzyme systems that help bring about oxidation-reduction reactions in plants' biochemical processes.

The lack of the several elements and micronutrients described above may explain the lack of healthy populations of Darwiniothamnus at the upper elevations of Volcan Ecuador. Similar results were also found on the southern coast of Santiago, near Cabo Nepean, where very low levels of Nitrate-nitrogen (1 ppm) and Potassium (48 ppm) were found. Although this location is home to a few plants of D. tenuifolius the small population size could be a result of the limited amount of these essential elements present in their environment. However, because typically only one soil sample was collected per site across the archipelago, the data is not sufficient enough to draw any strong conclusions, and all deductions made here are only based on preliminary data.

It is also worth pointing out that the only other location where soil was collected and where no species of Darwiniothamnus were found growing was on the island of Marchena. This island has been known for decades to be completely void of all members of the genus, however all of the values for each of the soil analyses run were within the accepted limits for healthy plant growth. It is therefore my preliminary hypothesis that some factor other than soil (such as chance or location of the island), is responsible for the complete lack of Darwiniothamnus on this island. All of the numerical data for the results described above can again be found in Tables 4.3, 5.3 and 6.3. 
Table 3.1: Invasive species in Galapagos, known or suspected to be causing significant ecological change (adapted from Tye, 2001)

\begin{tabular}{|c|c|}
\hline Family & Species \\
\hline$\overline{\text { Agavaceae }}$ & $\overline{\text { Furcraea cubensis (Jacq.) Vent. }}$ \\
\hline Bombacaceae & Ochroma pyramidale (Lam.) Urban \\
\hline Boraginaceae & Cordia alliodora (R. \& P.) Chum. \\
\hline Capparidaceae & Cleome viscosa $\mathrm{L}$. \\
\hline Crassulaceae & Kalanchoe pinnata (Lam.) Pers. \\
\hline Cucurbitaceae & Cucumis dipsaceus Ehr. \\
\hline Euphorbiaceae & Ricinus communis $L$. \\
\hline Lauraceae & Persea americana Mill. \\
\hline Leguminosae & Caesalpinia bonduc (L.) Roxb. \\
\hline Leguminosae & Cassia tora $\mathrm{L}$. \\
\hline Leguminosae & Leucaena leucocephala (Lam.) de Wit \\
\hline Meliaceae & Cedrela odorata $\mathrm{L}$. \\
\hline Myrtaceae & Eugenia jambos L. \\
\hline Myrtaceae & Psidium guajava L. \\
\hline Passifloraceae & Passiflora edulis Sims. \\
\hline Poaceae & Brachiaria mutica (Forssk.) Stapf \\
\hline Poaceae & Digitaria decumbens Stent. \\
\hline Poaceae & Melinis minutiflora Beauv. \\
\hline Poaceae & Panicum maximum Jacq. \\
\hline Poaceae & Panicum purpurascens Raddi \\
\hline Poaceae & Pennisetum clandestinum Hochst. \\
\hline Poaceae & Pennisetum purpureum Schum. \\
\hline Rosaceae & Rubus niveus Thunb. \\
\hline Rubiaceae & Cinchona pubescens Vahl \\
\hline Rutaceae & Citrus aurantiifolia (Christm.) Swingle \\
\hline Rutaceae & Citrus limetta Risso \\
\hline Rutaceae & Citrus limon (L.) Burn. \\
\hline Solanaceae & Cestrum auriculatum L'Her. \\
\hline Solanaceae & Datura stramonium $\mathbf{L}$. \\
\hline Solanaceae & Lycopersicon esculentum Mill. \\
\hline Ulmaceae & Trema micrantha (L.) Blume \\
\hline Verbenaceae & Lantana camara $\mathbf{L}$. \\
\hline
\end{tabular}


Table 3.2: Naturalized species, which are still relatively uncommon but are known to be damaging aggressives in other parts of the world or suspected of capacity to be so in

Galapagos (adapted from Tye, 2001).

(note: Most of those listed will probably move into Table 1 unless action is taken to control them)

\begin{tabular}{|c|c|}
\hline Family & Species \\
\hline$\overline{\text { Amaranthaceae }}$ & $\overline{\text { Amaranthus gracilis Desf. }}$ \\
\hline Anacardiaceae & Spondias purpurea $\mathrm{L}$. \\
\hline Annonaceae & Annona cherimolia Mill. \\
\hline Annonaceae & Annona muricata $\mathrm{L}$ \\
\hline Araceae & Colocasia esculenta (L.) Schott \\
\hline Asclepiadiaceae & Asclepias curassavica L. \\
\hline Asteraceae & Bidens cynapiifolia HBK. \\
\hline Asteraceae & Flaveria bidentis (L.) Kuntze \\
\hline Asteraceae & Gnaphalium purpureum L. \\
\hline Asteraceae & Porophyllum ruderale (Jacq.) Cass. \\
\hline Bixaceae & Bixa orellana $\mathrm{L}$. \\
\hline Brassicaceae & Raphanus sativus L. \\
\hline Cannaceae & Canna lutea Mill. \\
\hline Caricaceae & Carica papaya $\mathrm{L}$. \\
\hline Chenopodiaceae & Chenopodium ambrosioides $\mathbf{L}$. \\
\hline Chenopodiaceae & Chenopodium murale $\mathrm{L}$ \\
\hline Convolvulaceae & Ipomoea pulchella Roth \\
\hline Cyperaceae & Cyperus rotundus $\mathrm{L}$. \\
\hline Euphorbiaceae & Chamaesyce hirta (L.) Millsp. \\
\hline Euphorbiaceae & Jatropha curcas L. \\
\hline Leguminosae & Acacia nilotica (L.) DeLisle \\
\hline Leguminosae & Cassia bicapsularis $\mathbf{L}$ \\
\hline Leguminosae & Geoffroea spinosa Jacq. \\
\hline Leguminosae & Inga edulis Mart. \\
\hline Leguminosae & Lablab purpureus (L.) Sweet \\
\hline Leguminosae & Mimosa pigra $\mathrm{L}$ \\
\hline Lythraceae & Cuphea carthagenesis (Jacq.) Macbr. \\
\hline Malvaceae & Hibiscus diversifolius Jacq. \\
\hline Malvaceae & Hibiscus rosa-sinensis L. \\
\hline Malvaceae & Malachra alceifolia Jacq. \\
\hline Malvaceae & Malvastrum coromandelianum (L.) Garcke \\
\hline Meliaceae & Melia azederach $\mathbf{L}$. \\
\hline Nyctaginaceae & Mirabilis jalapa L. \\
\hline Papaveraceae & Argemone mexicana $\mathrm{L}$. \\
\hline Passifloraceae & Passiflora ligularis Juss. \\
\hline Passifloraceae & Passiflora quadrangularis L. \\
\hline Phytolaccaceae & Rivina humilis L. \\
\hline Piperaceae & Pothomorphe peltata (L.) Mig. \\
\hline Poaceae & Axonopus compressus (Sw.) Beaur. \\
\hline Poaceae & Bambusia guadua НВК. \\
\hline Poaceae & Cynodon dactylon (L.) Pers. \\
\hline Poaceae & Dactylotenium aegypticum (L.) Beauv. \\
\hline
\end{tabular}


Cont.

Poaceae

Poaceae

Polemoniaceae

Echinochloa colonum (L.) Link

Rubiaceae

Solanaceae

Solanaceae

Solanaceae

Solanaceae

Tiliaceae

Urticaceae

Verbenaceae

Eragrostis pilosa (L.) Beauv.

Phlox sp.

Coffea arabica $\mathbf{L}$.

Brugmansia candida L.

Datura innoxia Mill.

Nicotiana tabacum L.

Physalis peruviana L.

Triumfetta semitriloba Jacq.

Urera caracasana (Jacq.) Griseb.

Zingiberaceae

Verbena brasiliensis Vell.

Hedychium sp. 
Table 3.3: List of Soil Analyses run and methods used at the Growers Testing Service, Visalia, California:

Test:

$\mathrm{pH}$

$\underline{E C_{e}}(\mathrm{mmhos} / \mathrm{cm}$ or $\mathrm{dS} / \mathrm{m})$

Soluble CALCIUM/MAGNESIUM (meq/l)

Soluble SODIUM/POTASSIUM (meq/l)

CARBONATE+BICARBONATE $(\mathrm{meq} / \mathrm{l})$

CHLORIDE (meq/l)

FREE LIME (Calcium Carbonate)

SATURATION PERCENTAGE

NITRATE-NITROGEN

(ppm in saturation extract; ppm in dry soil)

PHOSPHORUS (ppm in dry soil)

Exchangeable $\mathrm{K}, \mathrm{Ca}, \mathrm{Mg}, \mathrm{Na}$

(ppm, meq/100 grams)

$\underline{\mathrm{Zn}}, \mathrm{Mn}, \mathrm{Fe}, \mathrm{Cu}(\mathrm{ppm}$ in dry soil)

BORON (ppm in saturation extract)
Type of Analysis:

Measured in the saturated paste after 1 hour.

Electrical conductivity of the saturation extract.

Measured in the saturation extract by Atomic Absorption, response enhanced with Lanthanum.

Measured in the saturation extract by Flame Emission.

Measured in the saturation extract by titration with $0.01 \mathrm{~N}$ Sulfuric Acid to Methyl Orange endpoint.

Measured in the saturation extract by titration with $0.01 \mathrm{~N}$ Silver Sulfate with Potassium Chromate indicator (Silver Chromate precipitate).

Fizz Test (none, low, medium or high)

Usually start with 200 grams of dried and ground soil and add deionized water until the paste meets the usual criteria. The saturated paste sits for at least 1 hour before further tests are begun.

Measured in the saturation extract using Phenoldisulfonic Acid detection colorimetric method.

$0.5 \mathrm{~N}$ Sodium Bicarbonate extraction, Ammonium Molybdate detection colorimetric method.

1N Ammonium Acetate extraction, Atomic Absorption/Flame Emission detection.

DPTA extraction, Atomic Absorption detection.

Azomethine $\mathrm{H}$ detection colorimetric method (AOAC) 
Cont.

ORGANIC MATTER (\%)

$\underline{\text { SAR }}$

$\mathrm{NH}_{4}-\mathrm{N}$ (ppm in dry soil)
Weight loss by combustion.

Calculated from measured soluble $\mathrm{Ca}, \mathrm{Mg} \&$ $\mathrm{K}$.

Extracted from soil with 1N Sulfuric Acid. Distilled from acid solution after making the extract alkaline (like a kjeldahl analysis without the digestion). 


\begin{tabular}{|c|c|c|}
\hline Sample no. & Species present & General Location \\
\hline 1 & $\overline{\text { Darwiniothamnus tenuifolius }}$ & Cartago Bay, Isabela \\
\hline 2 & D. tenuifolius & Cartago Bay, Isabela \\
\hline 3 & D. tenuifolius & Cartago Bay, Isabela \\
\hline 4 & D. tenuifolius & Cartago Bay, Isabela \\
\hline 5 & D. tenuifolius & trail up to V. Alcedo, Isabela \\
\hline 6 & D. tenuifolius & Cerro Cartago \\
\hline 7 & D.lancifolius & Volcan Ecuador \\
\hline 8 & & Volcan Ecuador \\
\hline 9 & D. tenuifolius & $2 / 3$ of the way up to $\mathrm{V}$. Alcedo \\
\hline 10 & D. lancifolius ssp. glandulosus & Volcan Wolff, Isabela \\
\hline 11 & D. lancifolius ssp. glandulosus & Cabo Douglas, Fernandina \\
\hline 12 & D. lancifolius ssp. glandulosus & Lava near Roca Tarzan, Fernandina \\
\hline 13 & D. lancifolius ssp. glandulosus & $\begin{array}{l}\text { Base of V. Fernandina, Fernandina } \\
\text { (lea. oddly very long and thin) }\end{array}$ \\
\hline 14 & D. lancifolius ssp. glandulosus & Volcan Darwin, Isabela \\
\hline 15 & same data as $\# 5$ & \\
\hline 16 & none & Volcan Ecuador \\
\hline 17 & D. tenuifolius & rim of Volcan Sierra Negra, Isab. \\
\hline 18 & D. lancifolius ssp. glabriusculus c & $\begin{array}{l}\text { in trail from rim to parking area, } \\
\text { Volcan Sierra Negra, Isabela }\end{array}$ \\
\hline 19 & D. alternifolius & Pampa "El Alemania," base of VSN, Isa. \\
\hline 20 & D. tenuifolius & $\begin{array}{l}\text { Sanitago highlands, in area around } \\
\text { GNPS house }\end{array}$ \\
\hline 21 & D. tenuifolius ssp. santacruzianus & Santa Cruz, south of Cerro Crocker \\
\hline 22 & none & $\begin{array}{l}\text { Marchena, inland from landing } \\
\text { place by Playa Negra }\end{array}$ \\
\hline 23 & none & $\begin{array}{l}\text { Marchena, inland close to Pta. Mejia, } \\
\text { facing Pinta }\end{array}$ \\
\hline 24 & D. tenuifolius, var. tomentosus? & $\begin{array}{l}\text { Pinta, up the new trail across from top of } \\
\text { Red } \\
\text { Hill }\end{array}$ \\
\hline 25 & D. tenuifolius, var. tomentosus? & $\begin{array}{l}\text { Pinta, approx. } 1 / 2 \mathrm{~km} \text { from last } \\
\text { collection site }\end{array}$ \\
\hline 26 & D. tenuifolius, var. tomentosus? & $\begin{array}{l}\text { Pinta, down old trail from Peak, heading } \\
\text { east }\end{array}$ \\
\hline 27 & D. tenuifolius & $\begin{array}{l}\text { Santiago, southern coast, south of } \\
\text { Cabo Nepean }\end{array}$ \\
\hline 28 & none & Cerro Azul, Isabela \\
\hline 29 & D. alternifolius and D. lancifolius & Cerro Azul, Isabela \\
\hline
\end{tabular}




\begin{tabular}{|c|c|}
\hline Sample no. & Location site information from field notes: \\
\hline & Dry rocky lava, good drainage \\
\hline 2 & Dry rocky lava, good drainage \\
\hline 3 & Dry rocky lava, some $\mathrm{dk}$. woody soil present \\
\hline 4 & Dry rocky lava, some dk. woody soil present \\
\hline 5 & $\begin{array}{l}\text { Scrub lands, muy cerado, not quite savannah, not far from new trail - browish } \\
\text { soil, no lava present }\end{array}$ \\
\hline 6 & $\begin{array}{l}\text { Rocky lava, undulating and some yellowish soil present as well; soil collected } \\
\text { near Cerro Cartago, where no Darwiniothamnus was found growing (soil much } \\
\text { more yellow) }\end{array}$ \\
\hline 7 & Plants growing in dirt between very dark (black) lava \\
\hline 8 & $\begin{array}{l}\text { Soil in transition zone between black lava and light brown lava, sample taken on } \\
\text { hillside }\end{array}$ \\
\hline 9 & Fern/sedge zone, plants surrounded by various grass spp. \\
\hline 10 & Light brown lava/dirt, plants both in soil and directly on rocks \\
\hline 11 & Medium dark grey and fine, taken inbetween lava stands \\
\hline 12 & $\begin{array}{l}\text { Sample taken in dirt past initial coastal strand of lava at first sight of a huge } \\
\text { population of Darwiniothamnus }\end{array}$ \\
\hline 13 & $\begin{array}{l}\text { Sample taken in a rocky river bed at interface with black lava where another } \\
\text { large population was found }\end{array}$ \\
\hline 14 & $\begin{array}{l}\text { Lava-gravel interface right before start of reddish lava, past tourist trail where } \\
\text { first Darwiniothamnus pop was found }\end{array}$ \\
\hline 15 & Repeat of sample \# 5 \\
\hline 16 & $\begin{array}{l}\text { Hillside, ascending base of volcano - sandy soil, no spp. of Darwiniothamnus } \\
\text { present from here on out, why? }\end{array}$ \\
\hline 17 & $\begin{array}{l}\text { Sample collected ca } 6 \mathrm{~km} \text { around crater from end of trail past sulfur plumes; } \\
\text { rocky soil and }+/ \text { - volcanic, with orange bits of pumice, soil very wet and } \\
\text { constitutes top most veg zone, fog abundant. }\end{array}$ \\
\hline 18 & $\begin{array}{l}\text { Sample taken off trail in }+/ \text { - pasture-land, still very moist, soil dark, no lava } \\
\text { present }\end{array}$ \\
\hline 19 & $+/$ - pasture land, still very moist, soil dark, no lava present \\
\hline 20 & Sample taken near a fenced off quadrant, lush veg, wet, rocky, dark brown soil \\
\hline 21 & $\begin{array}{l}\text { On way to Los Picachos, area densely covered with Pteridium aquilinum, moist } \\
\text { ground, brown clay-like soil }\end{array}$ \\
\hline 22 & $\begin{array}{l}\text { Soil very dry, light brown, somewhat rocky, lava present, but sample taken away } \\
\text { from lava }\end{array}$ \\
\hline 23 & Again, sample taken from soil/lava stand, very dry, light brown \\
\hline 24 & Reddish, dry soil, no lava present at this particular location \\
\hline 25 & Soil very dark, almost black, also dry and no lava present, dense vegetation \\
\hline 26 & Scrub zone, soil also black, nice clean, almost woody soil but not rocky \\
\hline 27 & $\begin{array}{l}\text { Very dry and hot area, huge lava stand, sample taken from within cracks of lava, } \\
\text { very shallow }\end{array}$ \\
\hline 28 & $\begin{array}{l}\text { Along the cassadores trail, up from Calleta Iguana and before reaching Media } \\
\text { Luna }\end{array}$ \\
\hline 29 & Just south of Media Luna \\
\hline
\end{tabular}




\section{Sample no. $\quad$ GPS data}

$$
1
$$

2

3

4

5

6

7

8

9

10

11

12

13

14

15

16

17

18

19

20

21

22

23

24

25

26

27

28

29

no data
$905688 \mathrm{~W}, 003735 \mathrm{~S}$

$905688 \mathrm{~W}, 003733 \mathrm{~S}$

$905713 \mathrm{~W} .003716 \mathrm{~S}$

$905706 \mathrm{~W}, 003716 \mathrm{~S}$

$910216 \mathrm{~W}, 002390 \mathrm{~S}$

$905715 \mathrm{~W}, 003720 \mathrm{~S}$

$913527 \mathrm{~W}, 000091 \mathrm{~S}$

$913522 \mathrm{~W}, 000098 \mathrm{~S}$

$910337 \mathrm{~W}, 002433 \mathrm{~S}$

$911304 \mathrm{~W}, 000125 \mathrm{~S}$

no GPS data,

$913904 \mathrm{~W}, 002334 \mathrm{~S}$

$913708 \mathrm{~W}, 002301 \mathrm{~S}$

$912193 \mathrm{~W}, 001495 \mathrm{~S}$

about $1 \mathrm{~km}$ north of $913515 \mathrm{~W} 000086 \mathrm{~S}$ none found

$911025 \mathrm{~W}, 004825 \mathrm{~S}$

$916626 \mathrm{~W}, 005034 \mathrm{~S}$

$911057 \mathrm{~W}, 005026 \mathrm{~S}$

$904603 \mathrm{~W}, 0013.18 \mathrm{~S}$

$901900 \mathrm{~W}, 003866 \mathrm{~S}$

$913207.1 \mathrm{~W}, 002121.71 \mathrm{~S}$

$904494 \mathrm{~W}, 003384 \mathrm{~N}$

$904516 \mathrm{~W}, 0034.12 \mathrm{~N}$

$904484 \mathrm{~W}, 003495 \mathrm{~N}$

$904915 \mathrm{~W}, 001915 \mathrm{~S}$

$9125.92 \mathrm{~W}, 005916 \mathrm{~S}$

$912552 \mathrm{~W}, 005812 \mathrm{~S}$
Qualitative assessment of the presence of Icerva purchasi (Cottony-cushion scale insect)

no data

all plants ca. $50 \%$ infected

none

none

most plants only $20-30 \%$ alive due to insect

no data, but black dot insect (feces?) abundant and plants w/ ca 50\% dieback

present, but not too abundant, healthiest plants yet seen

none found

none present

none present, but black dot "insects" mentioned above are present

none present

no notes

no notes

no notes

none present

none present

none present

yes, on Rinchosa minima

yes, on Rincosa minima

yes, everywhere!!! Several plants of

Darwiniothamnus tenuifolius are

dead and/or dieing

yes, everywhere!!! Several plants of $D$.

tenuifolius dead and/or dieing

none present

none appears to be present at this location

none

another kind of scale insect, but doesn't appear to be I. purchasi 
Table 3.5: Results of soil analyses for each collection site within the Galápagos Islands:

(Note: if more than one value is given, the first two numbers are the range and the second, followed by a comma, is the mean)

Island and collection location:

Isabela

Cartago Bay

Cerro Cartago

Volcan Alcedo

Volcan Wolff

Volcan Ecuador, lava strand near shore 7,8

Volcan Ecuador, base of Volcano $\quad 16$

Volcan Darwin

Sierra Negra (base of volcano)

Sierra Negra (El velasco)

Sierra Negra rim only

Cerro Azul

Just north of Media Luna, up from Calletta Iguana

Fernandina

Lava near Roca Tarzan

$\&$ base of V. Fernandina

Cabo Douglas

\section{Santa Cruz}

South of Cerro Crocker, near los Picachos

Santiago

highlands, near GNPS house 20

southern coast, south of Cabo Nepean 27

Marchena

Playa Negra \& inland near Pta. Mejia 22,23

Pinta

up new trail

down old trail
19

17

\section{soil sample \#s: species present:}

$\begin{array}{ll}1,2,3,4 & \text { D. tenuifolius } \\ 6 & \text { D. tenuifolius } \\ 5,9 & \text { D. tenuifolius } \\ 10 & \text { D. lancifolius ssp. glandulosus } \\ 7,8 & \text { D. lancifolius ssp. glandulosus } \\ 16 & \text { none } \\ 14 & \text { D. lancifolius ssp. glandulosus \& } \\ & \text { D. tenuifolius } \\ 18 & \text { D. lancifolius, ssp. glabriusculus } \\ & \text { only } \\ 19 & \text { D. lancifolius ssp. glabriusculus, } \\ & \text { D. tenuifolius, } \text { D. alternifolius } \\ 17 & \text { D. lancifolius ssp. glabriusculus \& } \\ & \text { D. tenuifolius } \text { only }\end{array}$

28,29

D. lancifolius ssp. glabriusculus \&

D. alternifolius only

12,13

D. lancifolius ssp. glandulosus

11

D. lancifolius ssp. glandulosus

21

D. tenuifolius ssp. santacruzianus 
Table 3.5 cont: Results of soil analyses for each collection site within the Galápagos Islands:

Note: if more than one value is given, the first two numbers are the range and the second, followed by a comma, is the mean)

\begin{tabular}{|c|c|c|c|c|}
\hline Soil sample \# & Spp. present & $\underline{\mathbf{H}}$ & Ece & Ca (meq) \\
\hline $1,2,3,4$ & D. tenuifolius & $5.6-7.6,6.93$ & $2.0-5.9,4.15$ & $7.69-15.82,11.42$ \\
\hline 6 & D. tenuifolius & 7.3 & 0.3 & 1.6 \\
\hline 5,9 & D. tenuifolius & $7.3-7.4,7.35$ & $1.1-3.1-2.1$ & $6.39-13.22,9.81$ \\
\hline 10 & $\begin{array}{l}\text { D. lancifolius } \\
\text { ssp. glandulosus }\end{array}$ & 8.2 & 1.3 & 5.34 \\
\hline 7,8 & $\begin{array}{l}\text { D. lancifolius } \\
\text { none }\end{array}$ & $\begin{array}{l}8.2-8.6,8.4 \\
8.5\end{array}$ & $\begin{array}{l}1.1-3.1-2.1 \\
0.3\end{array}$ & $\begin{array}{l}4.83-14.52,9.68 \\
0.4\end{array}$ \\
\hline 14 & $\begin{array}{l}\text { D. lancifolius } \\
\text { ssp. glandulosus } \\
\& \text { D. tenuifolius }\end{array}$ & 8.1 & 0.9 & 3.18 \\
\hline 18 & $\begin{array}{l}\text { D. lancifolius } \\
\text { ssp. glabriusculus }\end{array}$ & 5.4 & 0.3 & 0.77 \\
\hline 19 & $\begin{array}{l}\text { D. lancifolius } \\
\text { ssp. glabriusculus, } \\
\text { D. tenuifolius, } \\
\text { D. alternifolius }\end{array}$ & 5.4 & 1.1 & 8.33 \\
\hline 17 & $\begin{array}{l}\text { D. lancifolius } \\
\text { ssp. glabriusculus } \\
\& \text { D. tenuifolius only }\end{array}$ & 4.8 & 0.5 & 1.78 \\
\hline 28,29 & $\begin{array}{l}\text { D. lancifolius } \\
\text { ssp. glabriusculus } \\
\& \text { D. alternifolius only }\end{array}$ & $5.8-5.9,5.85$ & $.7-1.2, .95$ & $2.83-6.64,4.84$ \\
\hline 12,13 & $\begin{array}{l}\text { D. lancifolius } \\
\text { ssp. glandulosus }\end{array}$ & $6.9-7.0,6.96$ & $.8-3.4,2.1$ & $2.85-27.69,15.27$ \\
\hline 11 & $\begin{array}{l}\text { D. lancifolius } \\
\text { ssp. glandulosus }\end{array}$ & 6.6 & 2.5 & 11.83 \\
\hline 21 & $\begin{array}{l}\text { D. tenuifolius } \\
\text { ssp. santacruzianus }\end{array}$ & 5 & 0.4 & 1.09 \\
\hline 20 & D. tenuifolius & 6.1 & 1.4 & 3.22 \\
\hline 27 & D. tenuifolius & 7.5 & 0.2 & 0.89 \\
\hline 22,23 & none & $6.7-7.9,7.3$ & $.2-1.2, .7$ & $.78-3.61,2.20$ \\
\hline 24,25 & D. tenuifolius & $7.3-7.8,7.55$ & $.8-.8, .8$ & $3.43-4.10,3.77$ \\
\hline 26 & D. tenuifolius & 7.3 & 1.5 & 8.48 \\
\hline
\end{tabular}


Table 3.5 cont: Results of soil analyses for each collection site within the Galápagos Islands:

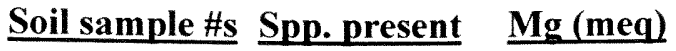

$1,2,3,4$

6

5,9

10

7,8

16

14

18

19

17

17

28,29

12,13

\section{1}

20

27

22,23

24,25

26

D. tenuifolius

D. tenuifolius

D. tenuifolius

D. lancifolius

ssp.

glandulosus

D. lancifolius

ssp.

glandulosus

none $\quad 0.28$

D. lancifolius 0.82

ssp.p .

glandulosus \&

D. tenuifolius

D. lancifolius, 0.81

ssp.

glabriusculus

D. lancifolius

ssp.

glabriusculus,

D. tenuifolius,

D. alternifolius

D. lancifolius 0.94

ssp.

glabriusculus \&

D. tenuifolius

D. lancifolius, $2.55-3.54,3.05$

ssp.

glabriusculus

\& D. alternifolius

D. lancifolius $\quad 2.63-6.33,4.485$

ssp.

glandulosus

1 D. lancifoliu

ssp.

glandulosus

D. tenuifolius 1.32

santacruzianus

D. tenuifolius 5.92

D. tenuifolius 0.48

none . 54-3.29, 1.92

D. tenuifolius $2.39-2.72,2.55$

D. tenuifolius 3.87
$\underline{\mathrm{Ca}+\mathrm{Mg} \text { (meq) }}$

$10.57-29.01,22.18$

2.28

$9.02-17.00,13.0$

7.4

$7.38-21.68,14.53$

0.68

4

1.58

1.17

9.43

0.91

2.72

1.7

$5.38-10.18,7.78$

$1.35-1.61$

$.48-34.02,19.75$

$1.74-2.18,1.96$

19.4

7.4

2.41

1.52

9.14

2.09

1.37

0.5

$1.32-6.9,1.01$

$.96-2.26,1.61$

$5.82-6.82,6.32$

12.35
1.74
$.96-1.13,1.05$ 
Table 3.5 cont: Results of soil analyses for each collection site within the Galápagos Islands:

(Note: if more than one value is given, the first two numbers are the range and the second, followed by a comma, is the mean)

\begin{tabular}{|c|c|c|c|c|}
\hline Soil sample \#: & $\underline{\text { Spp. present }}$ & $\underline{K}(\mathbf{m e q})$ & $K(\mathbf{p p m})$ & $\underline{P}(\mathbf{p p m})$ \\
\hline $1,2,3,4$ & D. tenuifolius & $2.15-7.39,4.62$ & $700-2020,1400$ & $6-42,28.5$ \\
\hline 6 & D. tenuifolius & 0.2 & 1990 & 29 \\
\hline 5,9 & D. tenuifolius & $4.19-4.54,4.33$ & $2190-2340,2265$ & $18-29,23.5$ \\
\hline 10 & $\begin{array}{l}\text { D. lancifolius } \\
\text { ssp. glandulosus }\end{array}$ & 1.13 & 1010 & 16 \\
\hline 7,8 & $\begin{array}{l}\text { D. lancifolius } \\
\text { ssp. glandulosus }\end{array}$ & $.15-1.92,1.04$ & $148-1000,574$ & $27-100,75.25$ \\
\hline 16 & none & 0.15 & 204 & 2 \\
\hline 14 & $\begin{array}{l}\text { D. lancifolius } \\
\text { ssp. glandulosus } \\
\& \text { D. tenuifolius }\end{array}$ & 1.15 & 128 & 7 \\
\hline 18 & $\begin{array}{l}\text { D. lancifolius, } \\
\text { ssp. glabriusculus }\end{array}$ & 0.68 & 306 & 6 \\
\hline 19 & $\begin{array}{l}\text { D. lancifolius } \\
\text { Ssp. glabriusculus, } \\
\text { D. tenuifolius, } \\
\text { D. alternifolius }\end{array}$ & 0.39 & 222 & 35 \\
\hline 17 & $\begin{array}{l}\text { D. lancifolius } \\
\text { ssp. glabriusculus } \\
\& \text { D. tenuifolius only }\end{array}$ & 0.63 & 214 & 32 \\
\hline 28,29 & $\begin{array}{l}\text { D. lancifolius, } \\
\text { ssp. glabriusculus } \\
\& \text { D. alternifolius only }\end{array}$ & $0.41-0.5,0.455$ & $180-236,208$ & $3-6,4.5$ \\
\hline 12,13 & $\begin{array}{l}\text { D. lancifolius } \\
\text { ssp. glandulosus }\end{array}$ & $0.56-2.33,1.45$ & $108-510,309$ & $15-32,23.5$ \\
\hline 11 & $\begin{array}{l}\text { D. lancifolius } \\
\text { ssp. glandulosus }\end{array}$ & 0.56 & 118 & 68 \\
\hline 21 & $\begin{array}{l}\text { D. tenuifolius } \\
\text { ssp. santacruzianus }\end{array}$ & 0.2 & 144 & 4 \\
\hline 20 & D. tenuifolius & 2.81 & 1090 & 6 \\
\hline 27 & D. tenuifolius & 0.1 & 48 & 7 \\
\hline 22,23 & none & $0.15-2.51,1.33$ & $344-720,532$ & $5-31,18$ \\
\hline 24,25 & D. tenuifolius & $0.39-0.74,0.57$ & $860-970,915$ & $20-27,23.5$ \\
\hline 26 & D. tenuifolius & 1.23 & 830 & 11 \\
\hline
\end{tabular}


Table 3.5 cont: Results of soil analyses for each collection site within the Galápagos Islands:

(Note: if more than one value is given, the first two numbers are the range and the second, followed by a comma, is the mean)

\begin{tabular}{|c|c|c|c|c|}
\hline Soil sample \#: & Spp.present & Carb (meq) & $\underline{\mathrm{Cl} \text { (meq) }}$ & $\frac{\text { Na adsorption }}{\text { ratio }}$ \\
\hline $1,2,3,4$ & D. tenuifolius & $3.4-27.8,16.05$ & $8.4-61.1,30.93$ & $1.31-8.45,5.19$ \\
\hline 6 & D. tenuifolius & 0.9 & 0.8 & 0.57 \\
\hline 5,9 & D. tenuifolius & $2.4-4.9,3.65$ & $3.5-9.8,6.65$ & $1.64-3.08,2.36$ \\
\hline 10 & $\begin{array}{l}\text { D. lancifolius } \\
\text { ssp. glandulosus }\end{array}$ & 4.3 & 4.4 & 2.24 \\
\hline 7,8 & $\begin{array}{l}\text { D. lancifolius } \\
\text { ssp. glandulosus }\end{array}$ & $3.2-8.7,6.0$ & $5.9-17.9,11.91$ & $0.77-3.04,2.4$ \\
\hline 16 & none & 0.7 & 2.2 & 4.48 \\
\hline 14 & $\begin{array}{l}\text { D. lancifolius } \\
\text { ssp. glandulosus } \\
\& \text { D. tenuifolius }\end{array}$ & 4.1 & 2.5 & 2.77 \\
\hline 18 & $\begin{array}{l}\text { D. lancifolius, } \\
\text { ssp. glabriusculus }\end{array}$ & 0.2 & 1.7 & 1.32 \\
\hline 19 & $\begin{array}{l}\text { D. lancifolius } \\
\text { ssp. glabriusculus, } \\
\text { D. tenuifolius, D. altern }\end{array}$ & $\begin{array}{l}0.2 \\
\text { ifolius }\end{array}$ & 0.9 & 0.42 \\
\hline 17 & $\begin{array}{l}\text { D. lancifolius } \\
\text { ssp. glabriusculus } \\
\& \text { D. tenuifolius only }\end{array}$ & 0.2 & 0.2 & 1.46 \\
\hline 28,29 & $\begin{array}{l}\text { D. lancifolius, } \\
\text { ssp. glabriusculus } \\
\& \text { D. alternifolius only }\end{array}$ & $0.4-0.6,0.5$ & $1.3-1.6,1.45$ & $0.71-.83,0.77$ \\
\hline 12,13 & $\begin{array}{l}\text { D. lancifolius } \\
\text { ssp. glandulosus }\end{array}$ & $0.3-1.9,1.1$ & $0.3-0.6,0.45$ & $0.42-1.32,0.87$ \\
\hline 11 & $\begin{array}{l}\text { D. lancifolius } \\
\text { ssp. glandulosus }\end{array}$ & 1.2 & 19.8 & 2.38 \\
\hline 21 & $\begin{array}{l}\text { D. tenuifolius } \\
\text { ssp. santacruzianus }\end{array}$ & 0.2 & 0.5 & 1.39 \\
\hline 20 & D. tenuifolius & 0.3 & 0.7 & 0.98 \\
\hline 27 & D. tenuifolius & 0.5 & 1 & 0.6 \\
\hline 22,23 & none & $0.7-3.1,1.9$ & $0.6-1.3,0.95$ & $1.18-1.22,1.2$ \\
\hline 24,25 & D. tenuifolius & $2.7-4.2,3.45$ & $0.6-3.23 .63$ & $0.56-0.61,0.59$ \\
\hline 26 & D. tenuifolius & 2.6 & 2.5 & 7.1 \\
\hline
\end{tabular}


Table 3.5 cont: Results of soil analyses for each collection site within the Galápagos Islands:

(Note: if more than one value is given, the first two numbers are the range and the second, followed by a comma, is the mean)

\begin{tabular}{|c|c|c|c|c|}
\hline Soil sample \#: & Spp. Present & $\begin{array}{l}\mathrm{Na} \\
\text { exchangeable \% }\end{array}$ & $\begin{array}{l}\mathrm{NO}_{4}-\mathrm{N}_{2} \\
\text { saturation extract (ppm) }\end{array}$ & $\begin{array}{l}\frac{\mathrm{NO}_{4}-\mathrm{N}}{\text { dry soil estimate }} \\
\underline{\text { s. }}\end{array}$ \\
\hline $1,2,3,4$ & D. tenuifolius & $.7-10.1,5.88$ & $30.0-62.0,43.25$ & $\begin{array}{l}\text { (ppm) } \\
47-117,70\end{array}$ \\
\hline 6 & D. tenuifolius & 0.1 & 18 & 9 \\
\hline 5,9 & D. tenuifolius & $1.2-3.2,2.2$ & $39.0-156.0,97.5$ & $28-147,87.5$ \\
\hline 10 & $\begin{array}{l}\text { D. lancifolius } \\
\text { ssp. glandulosus }\end{array}$ & 2 & 9 & 3 \\
\hline 7,8 & $\begin{array}{l}\text { D. lancifolius } \\
\text { ssp. glandulosus }\end{array}$ & $1.4-3.1,2.25$ & $4.0-7.1,5.55$ & $2-36,19$ \\
\hline 16 & none & 5.1 & 2 & 1 \\
\hline 14 & $\begin{array}{l}\text { D. lancifolius } \\
\text { ssp. glandulosus } \\
\text { \& D. tenuifolius }\end{array}$ & 2.8 & 47 & 14 \\
\hline 18 & $\begin{array}{l}\text { D. lancifolius } \\
\text { ssp. glabriusculus }\end{array}$ & 0.7 & 39 & 43 \\
\hline 19 & $\begin{array}{l}\text { D. lancifolius } \\
\text { ssp. glabriusculus, } \\
\text { D. tenuifolius, } \\
\text { D. alternifolius }\end{array}$ & 0.1 & 102 & 111 \\
\hline 17 & $\begin{array}{l}\text { D. lancifolius } \\
\text { ssp. glabriusculus } \\
\& \text { D. tenuifolius only }\end{array}$ & 9 & 3 & 3 \\
\hline 28,29 & $\begin{array}{l}\text { D. lancifolius, } \\
\text { ssp. glabriusculus } \\
\& D . \text { alternifolius only }\end{array}$ & $0.1-0.1,0.1$ & $76-153,114.5$ & $50-104,77$ \\
\hline 12,13 & $\begin{array}{l}\text { D. lancifolius } \\
\text { ssp. glandulosus }\end{array}$ & $0.1-0.7,0.4$ & $81-497,289$ & $27-249,138$ \\
\hline 11 & $\begin{array}{l}\text { D. lancifolius } \\
\text { ssp. glandulosus }\end{array}$ & 2.2 & 26 & 8 \\
\hline 21 & $\begin{array}{l}\text { D. tenuifolius } \\
\text { ssp. santacruzianus }\end{array}$ & 0.8 & 44 & 40 \\
\hline 20 & D. tenuifolius & 0.2 & 195 & 201 \\
\hline 27 & D. tenuifolius & 0.1 & 2 & 1 \\
\hline 22,23 & none & $0.5-0.5,0.5$ & $3-46,24.5$ & $1-30,15.5$ \\
\hline 24,25 & D. tenuifolius & $0.1-0.1,0.1$ & $16-20,18$ & $15-22,18.5$ \\
\hline 26 & D. tenuifolius & 0.1 & 144 & 219 \\
\hline
\end{tabular}


Table 3.5 cont: Results of soil analyses for each collection site within the Galápagos Islands:

(Note: if more than one value is given, the first two numbers are the range and the second, followed by a comma, is the mean)

\section{Soil sample \#:}

$1,2,3,4$

6

5,9

10

7,8

16

14

18

19

17

28,29

12,13

11

21

20

27

22,23

24,25

26

\section{Spp. present}

D. tenuifolius

D. tenuifolius

D. tenuifolius

D. lancifolius ssp.

glandulosus

D. lancifolius ssp.

glandulosus

none

D. lancifolius ssp.

glandulosus \& D. tenuifolius

D. lancifolius ssp.

glabriusculus only

D. lancifolius ssp.

glabriusculus, D. tenuifolius,

D. alternifolius

D. lancifolius ssp.

glabriusculus \& D. tenuifolius

D. lancifolius, ssp.

glabriusculus \& D. alternifolius

D. lancifolius ssp.

glandulosus

D. lancifolius ssp.

glandulosus

D. tenuifolius ssp.

santacruzianus

D. tenuifolius

D. tenuifolius

none

D. tenuifolius

D. tenuifolius
Boron (ppm)

$0.89-1.0,0.95$

0.3

$0.45-0.82,0.64$

1.41

$0.27-0.48,0.38$

0.24

0.48

0.24

0.22

0.27

$0.2-0.2,0.2$

$0.27-0.3,0.29$

0.3

0.13

0.22

1

$0.22-0.22,0.221 .0-2.7,1.35$

$0.2-0.22,0.21$

0.3
2.4

10.8

2.2

1.8

2.4

2.2

Zinc (ppm)

9.6-67.0, 45.4

1.6

$6.4-10.8,8.6$

2.4

$0.9-1.4,1.15$

0.4

2.4

$1.0-1.4,1.2$

$1.2-2.6,1.9$

0.6 


\begin{tabular}{|c|c|c|c|c|}
\hline Soil \#: & Spp. present & Mn (ppm) & $\mathrm{Fe}(\mathrm{ppm})$ & $\mathrm{Cu}$ (ppm) \\
\hline $1,2,3,4$ & $\overline{\text { D. tenuifolius }}$ & $\overline{42.0-72.0,53.0}$ & $12.0-70.0,17.5$ & $\overline{2.0-3.8,2.95}$ \\
\hline 6 & D. tenuifolius & 2.8 & 56 & 1.2 \\
\hline 5,9 & D. tenuifolius & $4.0-5.4,4.7$ & $36.0-37.0,36.5$ & $.8-2.0,1.4$ \\
\hline 10 & $\begin{array}{l}\text { D. lancifolius } \\
\text { glandulosus }\end{array}$ & 3.1 & 27.8 & 2 \\
\hline 7,8 & $\begin{array}{l}\text { D. lancifolius } \\
\text { ssp. } \\
\text { glandulosus }\end{array}$ & $.8-3.8,2.3$ & $35.6-43.0,39.3$ & $1.2-1.2,1.2$ \\
\hline 16 & none & 1.5 & 16.2 & 0.4 \\
\hline 14 & $\begin{array}{l}\text { D. lancifolius } \\
\text { ssp. } \\
\text { glandulosus } \\
\& \text { D. tenuifolius }\end{array}$ & 2.5 & 20 & 0.9 \\
\hline 18 & $\begin{array}{l}\text { D. lancifolius } \\
\text { ssp. } \\
\text { glabriusculus }\end{array}$ & 12.8 & 184 & 7.8 \\
\hline 19 & $\begin{array}{l}\text { D. lancifolius } \\
\text { ssp. } \\
\text { glabriusculus, } \\
\text { D. tenuifolius, } \\
\text { D. alternifolius }\end{array}$ & 2.8 & 85 & 6 \\
\hline 17 & $\begin{array}{l}\text { D. lancifolius } \\
\text { ssp. } \\
\text { glabriusculus } \\
\& \text { D. tenuifolius }\end{array}$ & 5 & 342 & 1.9 \\
\hline 28,29 & $\begin{array}{l}\text { D. lancifolius, } \\
\text { ssp. } \\
\text { glabriusculus } \\
\text { \& D. alternifoliu }\end{array}$ & $2.2-2.7,2.45$ & $57-60,58.5$ & $1.1-1.2,1.15$ \\
\hline 12,13 & $\begin{array}{l}\text { D. lancifolius } \\
\text { ssp. } \\
\text { glandulosus }\end{array}$ & $3.4-3.6,3.5$ & $23-37.6,30.3$ & $1.2-1.5,1.35$ \\
\hline 11 & $\begin{array}{l}\text { D. lancifolius } \\
\text { ssp. } \\
\text { glandulosus }\end{array}$ & 4.8 & 86 & 1.8 \\
\hline 21 & $\begin{array}{l}\text { D. tenuifolius } \\
\text { ssp. } \\
\text { santacruzianus }\end{array}$ & 12 & 20 & 0.8 \\
\hline $\begin{array}{l}20 \\
\text { Cont: }\end{array}$ & D. tenuifolius & 6.4 & 15.8 & 1 \\
\hline 27 & D. tenuifolius & 0.2 & 43 & 0.5 \\
\hline 22,23 & none & $1.2-4.1,2.65$ & $24.8-6.1,42.9$ & $1.0-2.6,1.8$ \\
\hline 24,25 & D. tenuifolius & $7.2-8.4,7.8$ & $78-78,78$ & $1.8-2.2,2.0$ \\
\hline 26 & D. tenuifolius & 10.7 & 103 & 2.4 \\
\hline
\end{tabular}


Table 3.6: Significant results of soil analyses (Mann-Whitney $U$ test, $\mathbf{p}<.05$ ):

(note: the number after each taxon represents the number of locations where each species was found growing out of all of the locations sampled)

\section{Taxa}

D. ten. (12/29)

D. ten. ssp. s.c. $(1 / 29)$

D. ten. var, tomen. (3/29)

D. lanc. ssp. glab. $(5 / 29)$

D. lanc. ssp. gland. (7/29)

D. altern. (3/29)

None $(3 / 29)$

\section{$\underline{\text { Fe }}$}

$Z=-2.08, p=.038$

$Z=-2.77, p=.006$

NO4-N

$\mathrm{Z}=-2.86, \mathrm{p}=.004$

$Z=-1.93, p=.037$

$Z=-1.94, p=.053$

Organic matter

$Z=-1.86, p=.063$

$Z=-2.905, p=.004$

$Z=-2.00, p=.045$

pH

$Z=-3.12, p=.002$

$Z=-2.04, p=.037$
Carb

Na (ad)

$\underline{N a(e x)}$

$Z=-1.86, p=.063$

$\mathrm{Z}=-2.08$,

$\mathrm{p}=.037$

$\underline{\mathrm{Ca}}$
D. ten. (12/29)
D. ten. ssp. s.c (1/29)
D. ten var. tomen. $(3 / 29)$
D. lanc. ssp. glab. $(5 / 29)$
D. lanc. ssp. gland. (7/29)
D. altern. (3/29)

None $(3 / 29)$

\section{Taxa}

D. ten. $(12 / 29)$

D. ten. ssp. s.c (1/29)

D. ten var. tomen. $(3 / 29)$

D. lanc. ssp. glab. $(5 / 29)$

D. lanc. ssp. gland. (7/29)

D. altern. (3/29)

None $(3 / 29)$

\section{Where:D. ten.}

D. ten. ssp. s.c.

D. ten. var. tomen.

D. lanc. ssp. glab

D. lanc. ssp. gland.

D. altern.

None

\footnotetext{
= Darwiniothammus temuifolius

$=D$. tenuifolius ssp. santacruzianus

$=D$. tenuifolius var. tomentosus

$=D$. lancifolius ssp. glabriusculus

$=D$. lancifolius ssp. glandulosus

$=D$. alternifolius

$=$ no species of Darwiniothamnus present at soil sample site
}

$$
\begin{aligned}
& Z=-1.93, \\
& p=.053
\end{aligned}
$$

\section{$\underline{\mathrm{Ca}+\mathrm{Mg}}$}

$Z=-2.01$

$\mathrm{p}=.045$ 
Figure 3.1: Distribution of Darwiniothamnus throughout the Galápagos Islands:

(courtesy of the CDRS plant science department GIS archives)

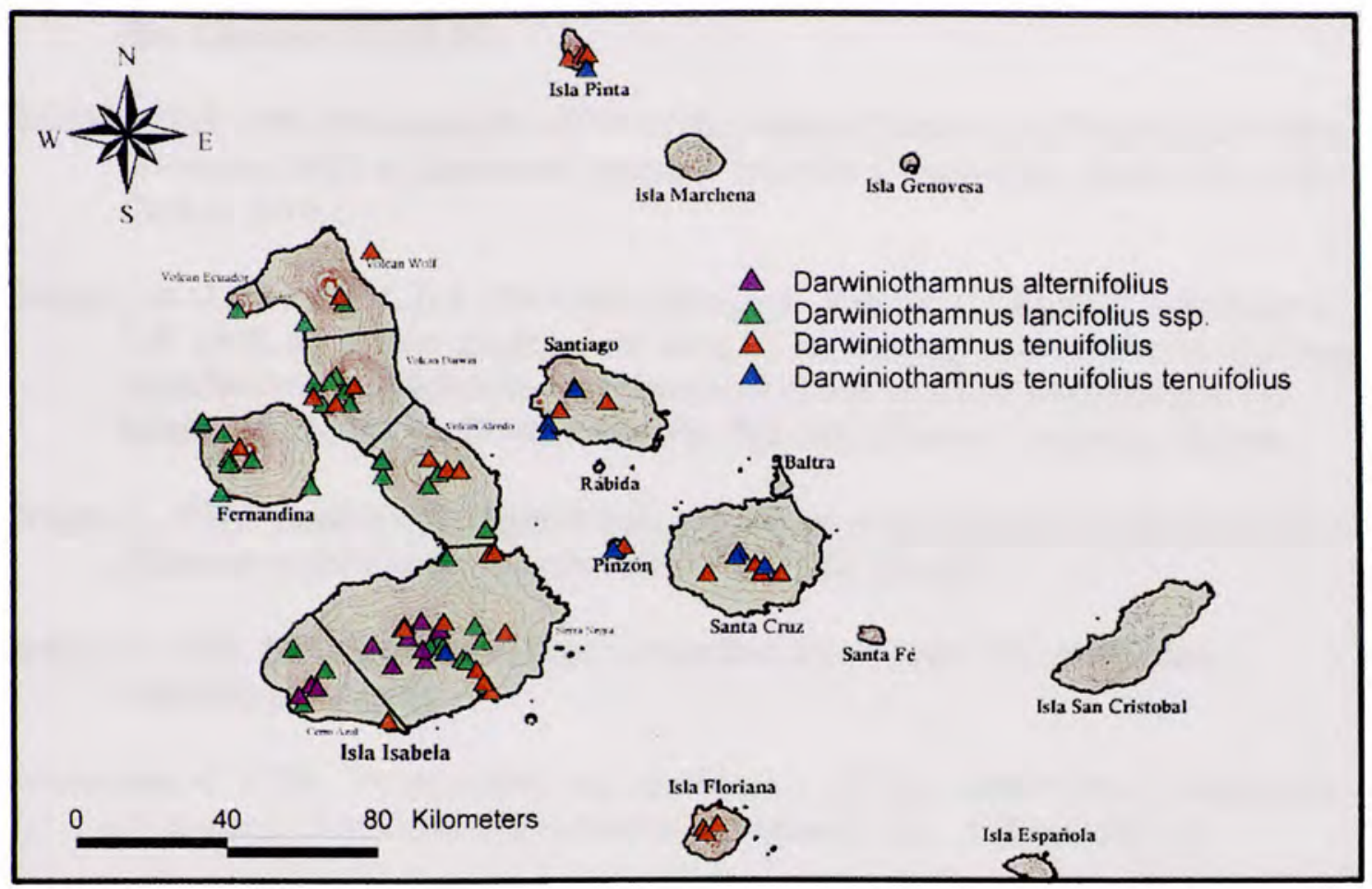




\section{REFERENCES}

Adsersen, H. 1989. The rare plants of the Galápagos Islands and their conservation. Bio. Conserv. 47: 49-77.

Baldwin, B.G. 1992. Phylogenetic utility of the Internal Transcribed Spacers of nuclear ribosomal DNA in plants: and example from the Compositae. Molec. Phy. and Evol. 1: 3-16.

Baldwin, B.G.; Crawford, D.J.; Francisco-Ortega, J.; Kim, S.-C.; Sang, T, and Stuessy, T.F. 1998. Molecular phylogenetic insights on the origin and evolution of oceanic island plants. In: Molecular systematics of plants II: DNA sequencing. (D.E. Soltis, P.S. Soltis, J.J. Doyle, eds.). Pp. 410-441. Kluwer Academic, Boston.

Borgen, L. 1976. Analysis of a hybrid swarm between Argyranthemum adauctum and A. filifolium in the Canary Islands. Nor. J. Bot. 23: 121-137.

Brady, N. 1990. The Nature and Properties of Soil. New York, NY: Macmillan Publishing Company.

Brochmann, C. 1984. Hybridization and distribution of Argyranthemum cornopifolium (Asteraceae-Anthemideae) in the Canary Islands. Nor. J. Bot.7:609-630.

Brockie, R. E. et al. 1988. Biological invasions of island nature reserves. Bio. Cons. 44: 9-36.

Cruz, F., Cruz, J. and Lawesson, J. 1986. Lantana camara, a threat to native plants and animals. Noticias de Galápagos 43: 10-11.

Davis et al. 1995. Centres of plant diversity: a guide and strategy for their conservation. Volume 2: Asia, Australasia and the Pacific. WWF and IUCN, Cambridge.

Francisco-Ortega, et al., 1997. Origin and Evolution of Argyranthemum (Ast. Anthemideae) in Macaronesia. In Molecular Evolution and Adaptive Radiation. Eds. Givnish and Systma.pp 407-431.

Hamann, O. 1984. Changes and threats to the vegetation. In Perry, R. (ed.), Key environments. Galápagos. Pergamon Press, Oxford. Pp. 115-131.

Hamann, O. 1991. Indigenous and alien plants in the Galápagos Islands: problems of conservation and development. In Heywood, V.H. and Wyse Jackson, P.S. (eds.), Tropical botanic gardens: their role in conservation and development. Academic Press, London. Pp. 169-192. 
Harling, G. 1962. On some Compositae endemic to the Galápagos Islands. Acta Hort. Berg. 20: 63-120.

Hoeck, H. 1984. Changes and threats to the vegetation. In: Perry R. (ed.), Key environments. Galápagos. Pergamon press, Oxford. 101-114

Hooker, J. D. 1847. On the Vegetation of the Galápagos Archipelago, as compared with that of some other Tropical Islands and of the Continent of America. Trans. Linn. Soc. 20: 235-262.

Key environments. Galápagos . Perry, R. ed. Pergamon press, Oxford. 1984.

Lawesson, J.E. and Adsersen, H. 1987. Notes on the endemic genus Darwiniothamnus Harling (Asteraceae, Astereae) from the Galápagos Islands. Op. Bot. 92:7-15.

Lawesson, J. 1990. Threatened plant species and priority plant conservation sites in the Galápagos Islands. Monogr. Syst. Bot. Miss. Bot. Gard. 32: 153-167.

Lawesson, J. E. and Ortiz, L. 1990. Plantas introducidas en las Islas Galápagos. In Lawesson et al (eds.) Botanical research and management in Galápagos. Missouri Botanical Garden, St. Louis, Missouri. Pp. 201-210.

Loope, L. L., Hamann, O., Stone, C.P. 1988. Comparative conservation biology of oceanic archipelagoes. Hawaii and the Galápagos. BioSci. 38: 272-282.

McMullen, Conley. 1999. Flowering Plants of the Galápagos Islands. Cornell: Cornell University Press.

Rivers, J. 2002. Interpretation of Soil Analyses. Visalia, CA: Scientific Agricultural Company.

Schilling, E. et al. 1994. Evidence from chloroplast DNA restriction site analysis on the relationships of Scalesia (Asteraceae: Heliantheae). A.J.B. 81: 248-254.

Schofield, E. 1973. Annotated Bibliography of Galápagos Botany. Ann. Miss. Bot. Garden 60: 461-477.

Sumner, M. 2000. Handbook of Soil Science. Boca Raton, FL: CRC Press.

Tye, A. 2001. Invasive plant problems and requirements for weed risk assessment in the Galapagos islands. Pp. 153-175 in: R.H. Groves, F.D. Panetta \& J.G. Virtue (eds) Weed Risk Assessment. CSIRO Publishing, Collingwood. 
Tye, A., Soria, M. \& Gardener, M.R. 2002. A strategy for Galapagos weeds. In: Veitch, C.R. \& Clout, M.N. (eds) Turning the Tide: the Eradication of Invasive Species. Invasive Species Specialist Group of The World Conservation Union (IUCN), Auckland. In press.

van der Werff, H. 1977. Vascular plants from the Galápagos Islands: new records and taxonomic notes. Bot. Not. 130: 89-100.

Wiggins, I and Porter, D. (1971) Flora of the Galápagos Islands. Stanford University Press. Stanford, CA. 


\section{Chapter IV: ORIGIN AND PHYLOGENETICS OF DARWINIOTHAMNUS}

\section{Introduction:}

Darwiniothamnus (Asteraceae: Astereae), as it is currently recognized, is one of seven endemic plant genera in the Galápagos Islands that has an unknown origin, although previous hypotheses have been made based upon various morphological analyses (Harling, 1962; Nesom, unpublished). Harling (1962) suggested that Darwiniothamnus' closest putative relatives may occur off the central coast of Chile, citing Erigeron berterianus DC. and E. litoralis (Phil.) Skottsberg as examples. He also mentioned, however, that the closest relative of Darwiniothamnus might instead be found in the Juan Fernández Islands, citing Erigeron fernandezianus (Colla), one of six species of Erigeron endemic to the Juan Fernandez Islands, as the primary example (Harling, 1962; Valdebenito et al., 1992). These two hypotheses were based primarily upon Harling's (1962) morphological research on the collections of Skottsberg and Sparre deposited in $\mathrm{S}$; where he stated that the species mentioned above might be related to Darwiniothamnus as they are all endemic and possess "a more or less suffrutescent habit" (Harling, 1962 and Skottsberg, 1922).

At the time of Harling's publication the best known of the species mentioned above was E. fernandezianus and Harling noticed that this species resembled Darwiniothamnus more than any other species of Erigeron. In specific, Harling stated that the two taxa were strikingly similar in that they both possessed inflorescences with pistillate flowers that were much more numerous than the hermaphroditic ones. However, he also reported several morphological differences between the two species 
that kept him from making any firm conclusions as to the definite origin of Darwiniothamnus. For example, the involucre of E. fernandezianus is hemispheric or broadly campanulate; its phyllaries are unequal in length, in imbricate series of 2-3; and the achenes of E. fernandezianus are homomorphic, rather than flat with an incrassate margin (Harling, 1962; Solbrig et al., 1969; cf. Skottsberg, 1922).

Harling went on to mention one additional potential biogeographical connection between Darwiniothamnus and two rather shrubby species of Erigeron (E. socorrensis and E. crenatus) from the Revillagigedo Islands, off the Pacific coast of Mexico (Harling, 1962; Johnston, 1931). However, he was uncertain of this connection as well, as although he recognized that Johnston (1931) had grouped these Revillagigedo species within the section Coenotus, he believed that this was not the same section to which the species of Darwiniothamnus and E. fernandezianus belonged.

A more recent study by Nesom (1989) has suggested that Darwiniothamnus may be more closely related to members of the primarily Mexican and Caribbean group Erigeron sect. Cincinnactis, due to their similarity in habit and form. Indeed, members of this group and the species of Darwiniothamnus are similar in that they all have leaves with toothed margins, rays that are filiform and numerous, achenes that are short-oblong and very small, and all are perennials with short, somewhat woody rhizomes (Nesom, 1989).

Nesom's (1989) hypothesis seems reasonable as the tendency for the evolutionary development of a woody habit in insular plants is well documented and can been observed in all of the examples listed above and in the previous chapter. In addition, Cronquist (1947) has stated that although the genus Erigeron is primarily herbaceous in 
its earliest lineages, it almost always becomes non-herbaceous in its more recently derived species. Carlquist (1974) has also provided examples of the Asteraceae and many other plant families in which genera with herbaceous mainland species have developed woody, insular species. Among those in the Asteraceae are insular species of Argyanthemum, Bidens, Centaurea, Daubautia, Dendroseris, Pertyle, Pulicaria, Remya, Robinsonia, Senecio, Sonchus and Stephanodoria (e.g. see Nesom, 1989; Carr, 1998; Sang, et al., 1994; Francisco-Ortega et al., 2001a,b; Crawford, et al., 1992; Crawford and Stuessy, 1987; Lowe and Abbott, 1996; Sanders et al., 1987). As in Darwiniothamnus, most of these species are rosette trees or rosette shrubs with long, mostly unbranched stems and leaves clustered near the stem tips.

Besides those of the Galápagos Islands, suffrutescent species of Erigeron with similar habits also have developed on the Revillagigedo Islands (E. socorrensis and $E$. crenatus), Caribbean (e.g. E. bellidiastroides, E. paucilobus, E. quercifolius, and $E$. karvinskianus), Canary (e.g. E. cabrerae Ditr.) and Juan Fernandez Islands (e.g. E. fernandezianus, E. ingae, and E. luteoviridis); suggesting that a connection based on the morphological similarity of Darwiniothamnus to another woody species from any one of these three areas could be possible (Johnston, 1931; Solbrig, 1962; Correl and Correll, 1982; Adams, 1972; and Alain, 1962).

\section{A brief description of the Astereae:}

The tribe Astereae is one of the largest tribes within the Asteraceae, both with respect to number of genera and number of species, and comes only second in number of species to the Senecioneae (Bremer, 1994). Most members of the Astereae are annual or perennial herbs or shrubs, however four genera including small to rarely tall trees are 
known to exist in South America (Baccharis), Australia-New Zealand (Olearia), and the island of St. Helena (Commidendron and Melanodendron). The Astereae are worldwide in distribution, but primarily concentrated in southwestern North America, South America along the Andes, South Africa, Australia and New Zealand (Bremer, 1994). Grau (1977) has further stated that most of the genera within the Astereae are distributed in and around land close to the Pacific and Indian oceans.

Grau (1977) performed one of the most detailed studies on members of the Astereae and found four characters by which members of the tribe could be recognized: the style (with special branch appendages), the anthers (which are typically obtuse at the base and without tails and spurs), the pollen (which is typically helianthoid) and the anatomy of the fruit (which have a testa epidermis with thick inner and radial cell walls, and thin outer walls). Both Bremer (1987) and Jones (1976) have also stated that the acute shape of the style branch appendages, which cross over during late anthesis, is also a good synapomorphy for the tribe. A limited amount of other anatomical characters have been listed by Baagoe (1978), Herz (1977) and Seaman (1982) that have been used to characterize members of the Astereae, however Bremer (1994) has stated that, in general, there are apparently few reliable synapomorphies for the tribe. In lieu of this fact, however, there are as of yet no indications that the tribe should be nonmonophyletic. Almost all of the genera hold together morphologically, and their tribal position is not questioned except in a few cases (Bremer, 1994).

More recently, various cpDNA (chloroplast) and nrDNA (nuclear ribosomal) studies of primarily North American members of the tribe Astereae have helped to clarify the phylogenetics of the Astereae (e.g. by Nesom (1989), Suh and Simpson (1990), 
Morgan and Simpson (1992), and Noyes (2000)). Morgan and Simpson (1992), in particular, studied 55 taxa of the Astereae and their work was extremely influential in helping to clarify relationships within the subtribe Solidagininae. Zhang and Bremer (1993) also performed a detailed cladistic analysis using 26 different morphological characters on 24 different genera from within the Grangeinae, Solidagininae and Asterinae subtribes. Their work helped to elucidate the phylogenetic relationships among these 24 genera and established the sister relationship between Erigeron and Vittadinia within the Asterinae.

\section{Relevant historical research on the genus Erigeron:}

The group of 24 genera that comprise the Conyza-Erigeron complex is one that is primarily united together based upon complex geographical distribution patterns and agamospermy (Noyes, 2000). This group comprises a major part of the tribe Astereae, and as stated by Bremer (1994) the group shows a "gradual trend from Aster with uniseriate, long ray florets through Erigeron with multiseriate rays to Conyza with multiseriate, more or less eradiate to filiform-tubular outer female florets, having been postulated by several authors (e.g. Cronquist, 1974)." The Erigeron/Conyza complex sensu lato includes the highly specialized genera Archibaccharis, Baccharis, and Heterothalamus, which collectively constitute the subtribe Baccharidinae; and Brachyactis, Chamaegeron, Conyza, Conysanthus, Darwiniothamnus, Erigeron, Heteroplexis, Hysterionica, Lachnophyllum, Laqennecia, Microglossa, Nidorella, Oreostemma, Oritrophium, Psiadia, Psiadiella, Psychrogeton, Rochonia, Sarcanthemum, Sommerfeltia and Trimorpha (Bremer, 1994). Zhang and Bremer (1993) have stated that multiseriate female florets, whether radiate (e.g. Erigeron) or minutely radiate to tubular 
(as in Conyza, Baccharis, and others), should be considered a potential synapomorphy for the entire group.

The genus Erigeron sensu stricto contains approximately 400 species, and a molecular phylogenetic study conducted by Noyes (2000) suggested a North American origin for Erigeron. This study also showed that Aphanostephus, Conyza, and three small genera to South America (Apropyros, Hysteronica and $\mathrm{Neja}$ ) are all nested within Erigeron. Currently 20 sections have been recognized within Erigeron (Nesom 1989, $1990,1994)$ which are all predominantly North American except for one which is from Brazil (sect. Leptostelma (D. Don) Benth and Hook). The most extensive taxonomic monographs of Erigeron have been completed for the species from North America by Cronquist (1947) and Nesom (1989); South American by Solbrig (1962); Europe by Halliday (1976); and Eurasia by Botschantzev (1959).

A "typical" species of Erigeron is one which Noyes (2000) states grows in a montane habitat and is a "monocephalous 'caudex'-branched herbaceous perennial with narrow white to pinkish rays, yellow disk, and oblanceolate leaves." This is not standard for all species of the genus, however, as considerable variation is known to occur in certain species. In specific, variation within Erigeron can often be seen in the following forms: members of the genus can be primarily herbaceous annuals or somewhat woody perennials; the ray color and ray to disk floret ratio may vary (e.g. from white to purple, pink or yellow); the amount of leaf dissection can vary (e.g. from highly dissected as in E. jamaicensis, to not dissected at all as in the currently recognized $D$. lancifolius); the breeding system of certain species can be outcrossing to selfing or agamospermus; and finally minute and/or technical floral variation also exists (Nesom, 1989). It should also 
be noted that while this variation may make it easier to identify a certain number of species, most members of this genus are often delimited using rather plastic microcharacters of achene type, and leaf, stem and/or involucre shape. These subtle differences often make it difficult to identify many species of Erigeron while in the field or in the herbarium. Indeed, as Noyes (2000) has stated: "there are surprisingly few hypotheses on either relationships within Erigeron or between Erigeron and related genera."

The systematics and evolution of Erigeron are considered to be closely linked with the morphologically similar genus Conyza (Noyes, 2000). Conyza comprises approximately 40 species, which span across both North and South America. The closest relatives to Conyza appear to be a number of widespread paleotropical (e.g. Nidorella and Microglossa; Wild, 1969) and Madagascan-Mascarene genera (e.g. Psiadia, Psiadiella, Rochonia, and Sarcanthemum; Bremer, 1994), and recent work by Nesom (1990b) and Noyes and Riesberg (1999) has shown that approximately 40 African species that were once traditionally included within Conyza are in fact more closely related to other African genera such as Nidorella.

\section{The value of using ITS sequences in phylogentic studies:}

The use of the ITS region for systematic botany was first described in Baldwin's 1992 paper on the phylogenetic utility of the ITS region in Hawaiian plants, specifically those within the Asteraceae family. Baldwin (1992) was one of the first to point out the shortcomings of studies based solely on cpDNA data and stated that "mounting evidence demonstrates that species-lineage reconstructions using the cytoplasmically inherited cpDNA may be prone to significant error from hybridization and introgression events or 
lineage sorting." Nuclear DNA is not without its shortcomings, however, and when seeking potentially useful nrDNA regions for phylogenetic use one should make sure the region is evolutionarily conservative, phylogenetically interpretable, easily examined in the laboratory, and sufficiently large to provide enough informative characters for analysis (Soltis et al. 1998; Baldwin, 1992).

The ITS region fits most of these characteristics, as its gene family (the 18-26S nrDNA region) often appears to undergo rapid concerted evolution making the many copies homogeneous and useful for phylogenetic reconstruction (Sanderson and Doyle, 1992). Noyes (2000) has also pointed out that because nrDNA is present in numerous copies, it is relatively easy to amplify from dried herbarium specimens of Erigeron and related genera. In addition, the results of Baldwin's study showed no ITS length variants or major sequence variants in any of the DNA he examined, which made the comparison and alignment of his sequences much easier. He did mention, however, that stabilizing selection on the ITS region has not been altogether sufficient to prevent broad-scale evolutionary diversity in ITS secondary structures, as can be seen when one tries to align two ITS sequences from different plant families. This therefore suggests a lack of longterm evolutionary constraint on much of the ITS region.

Since the time of Baldwin's initial study these spacers have been widely used to study members of the Asteraceae family and are especially useful at the infrageneric level (e.g. Baldwin et al., 1995, Kornkven et al., 1998, Noyes and Rieseberg, 1999 Torrell, et al., 1999, and Clevinger and Panero, 2000). Indeed, although the ITS region has been especially useful for sorting out the phylogenetics of organisms at the species and genus level, it is rarely used to detect within-species variation (Wem-Hsiung $\mathrm{Li}, 1997)$. In 
addition to the utility of the ITS region with members of the Asteraceae, several authors have used this spacer region to find the origin of genera such as Saintpaulia (Gesneraiaceae: Moller, M. and Cronk, Q, 1997) and Sanicula (Apiaceae: Vargas, et al., 1998) and to sort out the phylogenetics of the Apiaceae subfamily, the Apioideae (Downie, S. and Katz-Downie, D., 1996).

In relevance to this study, this region has also been successfully used to study the phylogenetics of various island endemic taxa. Downie et al. (2000) examined the evolutionary relationships among representatives of Old World Apiaceae, including several narrowly distributed endemic species. Francisco-Ortega et al. (2001) also used the ITS region to study the origin and evolution of the ten endemic Macaronesian members of the tribe Inuleae (Asteraceae), including three endemic genera Allagopappus, Schizogyne, and Vierea. This region has also been used successfully to establish phylogenetic relationships within Erigeron (Noyes, 2000) and between 55 genera of the tribe Astereae (Noyes and Rieseberg, 1999).

\section{Introduction into the phylogenetics of Darwiniothamnus:}

\section{i. Objectives of this study}

As previously mentioned, Darwiniothamnus, as currently defined, comprises three species of suffrutescent (D. alternifolius) to woody (D. tenuifolius and $D$. lancifolius) perennials. Ranging from coastal beach strands to mesic or humid scrub and forestlands, through lava and scoria fields and up to high elevation fern and sedge zones, it exists on seven different islands within the archipelago. Morphologically, these taxa are considered to be highly divergent from their continental relatives and have been suggested to be most closely related to woody Chilean members of the genus Erigeron 
(Asteraceae: Astereae) (Harling, 1962). However, a rigorous phylogenetic study of

Darwiniothamnus is needed in order to confirm or disprove its monophyly and to clarify the existing relationships between this genus and its putative South American relatives.

\section{ii. Materials and Methods}

\section{a. Sampling scheme:}

Any rigorous, non-circular study to trace the origin of island endemics must be based on a phylogeny derived from all available data. In order to test the origin of the genus currently recognized as Darwiniothamnus, I developed a molecular phylogeny based on the ITS region of the nrDNA gene. This region was chosen for this particular study because it has already been successfully used to establish phylogenetic relationships within Erigeron (Noyes, 2000) and between 55 genera of the tribe Astereae (Noyes and Rieseberg, 1999). Several of the 77 taxa included in Noyes' (2000) study (representing 20 different sections of Erigeron and four additional genera from the Erigeron-Conyza group) have been submitted to the GenBank database; and 28 of these sequences, representing an even sample of the six total clades produced in Noyes' (2000) phylogeny, were exported for use in this project.

In addition, in order to help trace the origin of Darwiniothamnus I also sequenced all the putative relatives listed in Harling's (1962) paper and 16 additional taxa from previously unsampled areas, including: Ecuador, the island of Socorro, Mexico, the Caribbean and Central America (see Table 4.1 for voucher information on all taxa included in this study). It should also be mentioned that leaf samples of all taxa sequenced in this study, save the ones collected by the author, were either sent from or collected by our colleagues in Chile, Argentina, Uruguay, Cuba, the Dominican Republic, 
Ecuador, Mexico, the United States, the Revillagigedo Islands and Puerto Rico.

Additional material was made available for study from herbarium specimens on loan from the following herbaria: FTG, HPPR, JBSD, S, GCD, HUMO, SGO, NY, AAU, ARIZ, C, CDS, CONC, GH, HUH, MO, Q, QCA, UC, and US.

Material of Darwiniothamnus included in this study was collected from six different islands within the Galápagos archipelago by the author and sequenced upon return to FTG/FIU. A few additional taxa were amplified or sequenced but not included in the phylogenetic analyses as their sequences were not clean enough to warrant their inclusion into my existing data matrix. These taxa, in no particular order are:

Sommerfeltia spinulosa, Neja filiformis, Erigeron procumbens, E. fuertesii, E. vegaensis, E. subalpinus and E. othonaefolius.

\section{b. Outgroup selection:}

Species chosen for the outgroup in this study are Oritrophium hieracioides, Pteronia incana, Chiliotrichum rosmarinifolium, Nardophyllum bryoides and $N$. obtusifolium. The first two species of this group were chosen based upon Noyes and Rieseberg's (1999) paper on the origin of the tribe Astereae. Both $O$. hieracioides and $P$. incana are of the subtribe Hinterhuberinae and were part of the basal group in Noyes and Reiseberg's (1999) paper, separated from all other Astereae included in their phylogeny by bootstrap values of $76-96 \%$.

The other two genera included in my outgroup, Chiliotrichum and Nardophyllum, are restricted to South America, contain very few species and are nested within the tribe Astereae. The three species from these two genera included in my study (Chiliotrichum rosmarinifolium, Nardophyllum bryoides and $N$. obtusifolium) were initially added as 
members of my ingroup; however, in all of the prelimiary phylogenetic analyses

performed, each came out included within the outgroup so I chose to leave them there as additional taxa were added to my phylogeny.

\section{c. Molecular methodology:}

All leaf material used in this study came from one of two sources: 1.) picked fresh and stored in silica gel, or 2.) taken from dried leaf material from herbarium samples. A list of the voucher specimens and locality information can be found in Table 4.1, along with the accession numbers for the sequences imported from GenBank for use in my phylogeny.

DNA was extracted using the following protocols, depending on whether freshly dried or dried herbarium leaf material was used: freshly dried leaf material stored in silica gel was first frozen in liquid nitrogen and then ground to a fine powder, whereas leaf fragments taken from herbarium specimens were ground dry using fine white sand. CTAB (hexadecyltrimethylammonium bromide) was occasionally added to this grinding process if it proved difficult to extract DNA from a pure, frozen or sand-induced grind. For the most part, DNeasy Plant Mini Kit (Qiagen, Inc., Valencia, CA) columns were used for DNA extractions; however, if the herbarium specimens used to extract DNA in this project were over 25 years old, better extractions resulted when using the $2 \mathrm{X}$ CTAB protocols of Doyle and Doyle (1987).

Prior to amplification by the polymerase chain reaction (PCR) the DNA samples were further purified by the Geneclean procedure (Bio. 101, Vista, CA), a process that entails binding DNA to tiny silica beads, washing with an ethanol/salt solution, and eluting the purified DNA in TE. The entire ITS1-5.8S-ITS2 region of the nuclear 
ribosomal DNA was then amplified using the P1A and P4 ITS primers and following the PCR protocols of Francisco-Ortegta et al (1999) on a PTC-200 thermal cycler (MJ Research, Watertown, MA). It should be noted that in a few cases the initial amplification of certain taxa was problematic, and ITS 1 and ITS 2 had to be amplified separately using the primers described in the next paragraph. Upon successful amplification, the PCR product was then purified using a QIAquick PCR purification kit (Qiagen Inc., Valencia, CA) according to the instructions of the manufacturer, or following the Geneclean procedures described above. Total nr DNA (18S-26S) was then quantified by fluorometry.

After purification, the PCR product was sequenced using the ABI Prism BigDye $^{\mathrm{TM}}$, Terminator Cycle Sequencing Ready Reaction Kit (Perkin Elmer, Applied Biosystems, Foster City, CA) with AmpliTaq DNA polymerase. Sequencing was performed in both the forward and reverse directions using the P1A (GGA AGG AGA AGT CGT AAC AAG G) and P2 (CTC GAT GGA ACA CGG GAT TCT GC) primers for ITS 1, and the P3 (GCA TCG ATG AAG AAC GCA GC) and P4 (TCC TCC GCT TAT TGA TAT GC) primers for ITS 2 (Integrated DNA Tech: White et al., 1990; Downie and Katz-Downie, 1996). Reactions were carried out in $10 \mu$ volumes, with the Terminator Mix diluted 50:50 with Aplitaq FS buffer.

Cycle sequencing conditions consisted of an initial denaturation at $96^{\circ}$ for 2 minutes, followed by 35 cycles of $96^{\circ}$ denaturation for 10 seconds, $55^{\circ}$ primer annealing for 5 seconds, and $60^{\circ}$ extension for 4 minutes. The product of this sequencing reaction was then precipitated with $\mathrm{EtOH} / \mathrm{NaNH}_{4} \mathrm{Oac}(6: 1)$, the pellet dried under vacuum, 
resuspended in formamaide/blue dextran loading dye (5:1) and loaded on an ABI 377 automated sequencer.

\section{d. Phylogenetic Analyses:}

DNA fragments were assembled using Sequencher version 3.0 (Gene Codes Corporation, Ann Arbor, MI) or Seqapp (Gilbert, 1993), and aligned using Clustal X (Thompson et al., 1997) with minor manual adjustments. Default Clustal X parameters were used for gap opening costs (10.00) and gap extension costs (0.05). All nucleotide characters were unordered, with equal weight. Fifty-three gaps were coded in MacClade version 4.03 (Maddison \& Maddison) as binary characters, A or C, according to their presence or absence (Simmons and Ochoterena's, 2000). Phylogenetic reconstruction was conducted using maximum parsimony methods as implemented in PAUP* version 4.0 (Swofford, 1990), following the perameters described below.

A heuristic search was performed on the 53 sequences using the following criteria: maxtrees 20,$000 ; 1,000$ random taxon addition replicates; tree bisection and reconstruction (TBR) branch swapping; no more than 10 trees saved for each repetition. TBR branch swapping was performed on all of the trees retained in memory from the first search. The Consistency Index (CI) (Kluge and Farris, 1969) and Retention Index (RI) (Farris, 1989) were also computed for each analysis.

Bootstrap support values were calculated by conducting 100 bootstrap replicates with the following criteria: maxtrees 20,$000 ; 1,000$ random taxon addition replicates; tree bisection and reconstruction (TBR) branch swapping; no more than 10 trees saved for each repetition. TBR branch swapping was performed on all of the trees retained in memory from the first search. 
Constraint trees with all the species of Darwiniothamnus forming a monophyletic group were also executed in order to test the hypothesis that all the species of this genus form a monophyletic assemblage. Tree scores of the constraint trees were compared to those of unconstrained trees and the results are confered in the discussion section below.

Finally, nine areas of endemism were also defined for the purpose of a biogeographical study. These areas include the following geographical locations and the numbers in parentheses indicate the number of taxa included in my phylogeny that occur in each area: SE USA (5); SW USA (9); Central/Northern USA (12); The Caribbean basin, including Mexico (19); Central America (2); West (Pacific) South America (7); East (Atlantic) South America (2); The Galápagos Islands (6); South Africa and Asia (2). It should be noted that some species' ranges (e.g. Erigeron scaberrimus, E. quercifolius, E. tenuis, Aphanosstephus skirrhobasis, A. ramosissimus, Hetertheca villosa, Chrysopsis gossypina, Rigiopappus leptocladus, Aster amellus and Chiliotrichum rosmarinifolium) extend into more than one geographical range, and were thus coded as multistate characters.

This biogeographic analysis was performed in order to identify the ancestral areas of Darwiniothamnus. In specific, after the 10 separate areas of endemism (listed above) were defined, they were coded as unordered characters in MacClade version 4.03 (Maddison \& Maddison) and the character state changes were traced on one of the most parsimonious trees imported from Paup*, using the parsimony methods implemented in MacClade. 


\section{iii. Results}

Unweighted parsimony analyses yielded 96 most parsimonious trees, each 778 steps long $(\mathrm{c} . \mathrm{i} .=0.486$, r.i. $=0.712$, and r.c $=0.338)$, from the $4,181,138$ rearrangements performed in the final heuristic search. One of these 96 trees can be found in Figure 4.1 and dashed lines show where the branches collapse in a strict consensus tree. Seven groups can be identified in the strict consensus tree, which are easily depicted in the phylogeny of Figure 4.1. Group I is a monophyletic clade and it is composed of 6 species of Erigeron from Mexico, the Caribbean Islands and North America. Group II is a clade that contains three independent, monophyletic subclades. The first of these clades includes four shrubby taxa of Darwiniothamnus and is sister to E. bellidiastroides of the Caribbean. The second clade within Group II is composed of three species also from the Caribbean Islands and one that is from Mexico. The third subclade comprises two species of the genus Aphanosstephus, which is from the Southwestern U.S. and Mexico.

Group III contains species from the following three genera: Erigeron, Darwiniothamnus and Conyza. The two semi-herbaceous members of Darwiniothamnus are sister to two species of Erigeron from the coast of Chile and are nested within a larger clade comprising of species primarily found in South America. Group IV, comprises two genera (Erigeron and one species of Conyza) that are distributed only throughout North America and Mexico, and the same is true for Group V. Group VI constitutes a grade of six assemblages and contains species of Erigeron, Hetertheca, Chrysopsis, Rigiopappus, Aster and Kalimeris from Mexico, North America and South America. Finally, Group VII consists of all the outgroup species which were discussed in the previous section of this paper. 
One of the most significant results produced from this phylogeny is the dissolution of the previously held notion that all members of the genus Darwiniothamnus constitute a monophyletic group. This is clearly not the case, as the woody shrub-like members of the genus, $D$. tenuifolius and $D$. lancifolius, come out in a completely separate clade from the single semi-herbaceous species, $D$. alternifolius, recently described by Lawesson and Adsersen (1987). Two representatives of both D. tenuifolius and $D$. lancifolius were included in this phylogeny and while all four taxa comprise a monophyletic group they are nested within a clade containing some of the Caribbean species of the genus Erigeron.

In addition, two representatives of $D$. alternifolius were also included in this phylogeny from the two separate locations where the species is known to exist on the southern tip of Isabela in the Galápagos Islands. Both sequences of this species were resolved within a clade of primarily South American species of Erigeron, and the results suggest that Darwiniothamnus stems from two separate introductions into the Galápagos Islands.

The formation of the constraint tree in both MacClade and Paup*, which forced all taxa of Darwiniothamnus included in this study to be monophyletic, was 799 steps long, or 21 steps longer than the 96 most parsimonious trees found after an unconstrained heuristic search was performed.

Finally, the biogeographic analysis performed in order to identify the ancestral areas also yielded some results relevant to the origin of Darwiniothamnus (see Figure 4.2). For example, based on our sampling, it appears that $D$. lancifolius and $D$. tenuifolius have their ancestral area, or location of origin, in the Caribbean basin as 
evidenced by the pattern-coded areas of endemism on the phylogeny in Figure 4.2. It also appears clear that the second introduction of Darwiniothamnus was from South America as $D$. alternifolius clearly stems from this region, again evidenced by the tracing of ancestral areas in Figure 4.2. Both of these findings support the notion that Darwiniothamnus, as it is currently recognized, arose from two separate introductions into the Galápagos Islands.

\section{iv. Discussion}

Data from the ITS region of nrDNA provided strong support for the inclusion of Darwiniothamnus within Erigeron. Both groups of the polyphyletic Darwiniothamnus were nested well within clades consisting solely of members from the Erigeron-Conyza complex. Based on our sampling, Erigeron bellidiastroides of Cuba is the sister group (Fig. 4.1) of Darwiniothamnus tenuifolius and D. lancifolius; whereas Erigeron luxurians and E. fasciculatus from the central coast of Chile are the sister group of Darwiniothamnus alternifolius (Fig. 4.1). Therefore, it appears that Darwiniothamnus, as the genus is currently recognized, not only stems from two separate introductions into the Galápagos Islands, but also represents two separate evolutionary lineages whose current taxonomy ought to be reconsidered.

Although the habit of Darwiniothamnus tenuifolius and D. lancifolius (both ssp. glandulosus and glabriusculus) appears to be greatly divergent from Erigeron bellidiastroides (the former are rather large woody shrubs while the latter is a small herbaceous-suffrutescent perennial), the evolution of a woody habit from an herbaceous one is a common island syndrome that has been discussed by many authors (e.g. 
Cronquist, 1970, 1971; Carlquist, 1974; Harling, 1962; Nesom, 1989; Shilling et al., 1994; Whittaker, 1998).

Sanders et al. (1987) have mentioned the importance of the environment in dictating ways in which different members within a certain clade can be found to be both very morphologically divergent and genetically similar at the same time. Two prime examples of this idea can be found in the Silversword alliance and the genus Dendroseris, from the Hawaiian and Juan Fernandez Islands, respectively. The mainland counterparts of these two groups are both much smaller and less woody, yet genetically rather similar to their island relatives. Carlquist (1974) has also provided several examples from the Asteraceae, and many other plant families, where genera with herbaceous mainland species have developed woody, insular species. Among those in the Asteraceae are insular species of Bidens, Centaurea, Daubautia, Pertyle, Remya, Robinsonia, Senecio, Sonchus and Stephanodoria (e.g. see Nesom, 1989; Carr, 1998; Sang, et al., 1994; Francisco-Ortega et al., 2001a,b; Crawford, et al., 1992; Crawford and Stuessy, 1987; Lowe and Abbott, 1996; Sanders et al., 1987).

In addition, although the plant sizes of the Galápagos (D. tenuifolius and $D$. lancifolius) and Cuban (E. bellidiastroides) endemic sister taxa are not the same, several similarities do exist between them. For example, the leaves of both plants are ovateobovate, puberulent and condensed in either basal (as in E. bellidiastroides) or terminal (e.g. D. tenuifolius \& D. lancifolius) whorls. In addition both groups are monocephalous, with filiform pedicels and linear-lancolate bracts making up the capitula.

Several similar connections can also be drawn between the Galápagos and Chilean endemic sister taxa, D. alternifolius and E. luxurians/E. fasciculatus, 
respectively. Several authors have noted that D. alternifolius (Lawesson and Adsersen, 1987; Nesom, unpublished), does not share all of the characters by which the other members of the genus are defined. For example, the leaves of this species are alternate and not in condensed in terminal whorls, the plant is typically a suffrutescent perennial which does not exceed 1 foot in height, and it often has branching peduncles forming cymiform synflorescences. Many of these characters are also found in E. luxurians and E. fasciculatus as both of these species are subshrubs, or suffrutescent perennials; both have leaf scars readily present; and both have leaves that are pubescent to very pubescent and crowded in the basal part of the plant but rather scattered at the ends of the branches (as does D. alternifolius). E. luxurians and E. fasciculatus are also polycephalous and generally look more like $D$. alternifolius that the other species of the same genus. Because the two sequences of $D$. alternifolius, (from Cerro Azul and Volcan Sierra Negra, respectively), clustered together in group III far from the rest of the species of Darwiniothamnus, I suggest renaming this taxon as Erigeron alternifolius comb. nov. (see the section on Nomenclatual Conclusions).

\section{a. A Caribbean origin}

When considering the biogeographic connections between Darwiniothamnus and its two apparent origins, the notion of a connection between the Caribbean and the Galápagos Islands is not as novel as it might first appear. The first paper to discuss the geographic relationships of the Galápagos flora (Hooker, 1847) mentioned that the flora of the Galápagos could be divided into two distinct elements: "the peculiar or new species being for the most part allied to plants of the cooler parts of America, or the uplands of the tropical latitudes, whilst the non-peculiar are the same as abound chiefly in 
the hot and damper regions, as the West Indian islands and the shores of the Gulf of Mexico." Porter (1983) has stated that Hooker's "peculiar" element probably corresponded primarily to taxa of Andean origin, while the "non-peculiar" element corresponded to Tropical and Pantropical America.

In addition to Hooker's hypotheses, N. J. Andersson (1857), who generally supported the views of Hooker, stated that a number of species in the Galápagos flora also have pantropical distributions, an element which was not previously emphasized by Hooker. Takhtajan (1988) has also stated in his seminal work on plant biogeography, that the Caribbean Region has floristic ties not only with the coasts of Mexico, Florida, most of Central America and northern South America; but also may be closely allied with Cocos and the Galápagos Islands. Although Takhtajan (1988) did not specifically say how such floristic connections were developed throughout these various areas, it is clear that he understood a connection between the Caribbean and Galápagos was possible.

In addition to the papers mentioned above, Porter (1979) also placed an important emphasis on West Indian relationships and his ideas have transcended into several of the papers discussed below. For example, Sesuvium edmonstonei, formerly regarded as a Galápagos endemic, has been found by Eliasson (1996) to occur on the Caribbean coast of both Colombia, Venezuela and their offshore islets. Valdebenito et al. (1990) documented an inter-population separation (disjunction) for the plant genus Peperomia (Piperaceae), of more than $5,000 \mathrm{~km}$, one of the longest known in flowering plants. They attributed long-distance dispersal by birds as the most likely cause of the wide disjunction. Valdebenito et al.'s (1990) paper is of special interest in light of the recent findings of Sato et al. (2001). Sato et al. (2001) recently discovered that the initial 
adaptive radiation of the Tiaris group, the nearest living relative of Darwin's finches, occurred on the Caribbean islands and then spread to Central and South America.

Because all species of Darwiniothamnus have a bristle-like pappus and are considered to be transported by wind (as in grasses) and/or by birds (as in the finches), both Valdebenito's (1990) and Sato et al.'s (2001) hypotheses seem to provide reasonable vectors for the transportation of the ancestral lineage of Darwinothamnus to the Galápagos Islands.

Finally, Grehan (2001) distinguished three principal tracks that connect the Galápagos with the East Pacific, the Caribbean and the Pacific basin. In specific, he stated that the Galápagos Islands lie in a nodal position of three potential tracts (the EastPacific, the Pacific and the Galápagos-Caribbean tracks), with respect to the biogeographic history of the region. Grehan's (2001) ideas thus support Wiggins (1966) findings which state that there are two major sources of grasses reaching the Galápagos Islands before man began to carry them about: the Mexico-West Indies area and South America. This of course, is the same biogeographical hypothesis that I propose for Darwiniothamnus, as it most likely also stemmed from two separate introductions.

\section{b. A South American origin:}

In spite of the research discussed above, it should be noted that in general, the flora of the Galápagos Islands has long been thought to originate and have several common elements in mainland of South America; with only a few species (1\%) having been formally recognized to be of Mexican and Central American origin (Porter, 1976). Good (1964) delimited what he considered to be the major floristic regions of the world and grouped the Galápagos with the western coast of South America, and said that the 
floristic affinities of the Galápagos could probably only come from this region. Perry (1984) has stated that virtually all of the endemic species of the Galápagos have their closest relatives in South America except for the bryophytes, where mosses tend to show an aberrant and close correlation with Central America, most likely attributed to dispersal by the trade winds.

In addition, Porter (1983) has mentioned several other authors who support an Andean origin for most Galápagos plants including: Robinson and Greenman (1895); Stewart (1911), Wiggins (1966), and Porter (1976). The first author to document the close relationship of Galápagos plants to Ecuador and Peru, in specific, was Svenson (1935, 1946); he was followed by Harling (1962), who discussed the possibility of a relationship between several Galápagos endemics, including Darwiniothamnus, to certain plant species of Chile and the Juan Fernandez Islands. From the results of this thesis, it seems that Harling's hypothesis was at least partially correct as based upon my sampling, the two specimens of $D$. alternifolius included this thesis came out sister to $E$. fasciculatus and E. luxurians of Chile, just as Harling had hypothesized.

In closing, Carlquist (1965) interpreted both the paucity of endemic Galápagos plant genera and their close relationships with American mainland groups as evidence for recent origin (Grehan, 2001). This appears to hold true for the origin of D. alternifolius as its morphology has remained relatively similar to its sister taxa E. fasciculatus and $E$. luxurians. Carlquist (1965) also regarded the Galápagos flora as purely that of an oceanic island; where plant families with good long-distance dispersal ability were the most abundant and groups with poor dispersal ability were absent. This appears to be true, at least in the case of $D$. tenuifolius and $D$. lancifolius, which are sister to Caribbean 
species of Erigeron, appear to have reached to the Galápagos via long-distance dispersal, and then radiated into several new species and subspecies that are now spread throughout seven different islands within the archipelago.

\section{Concluding Remarks to all the chapters:}

Below is a concise response to the five research questions that I mentioned at the beginning of this thesis, namely:

1. What is the conservation status of all currently recognized taxa within the genus Darwiniothamnus, and do any new conservation measures need to be implemented?

2. Based upon field observations, do any areas contain new morphological variants that warrant in-depth morphological studies?

3. What are the existing biological threats to Darwiniothamnus and what can be done to protect these populations in the future?

4. Does the lack or over-abundance of certain essential elements and/or micronutrients prevent Darwiniothamnus from colonizing certain areas of the archipelago?

5. Where is the origin of Darwiniothamnus and is the genus monophyletic?

In regards to question \#1: the current conservation status of Darwiniothamnus is not determined easily and appears to depend upon on the island environment in which it the plant is growing. Most taxa of $D$. lancifolius appear to be in good health, especially on the rather untouched island of Fernandina and most populations of $D$. lancifolius appear to be unaffected by the introduction of I. purchasi, except for the population on Bahia Urvina. It is my suggestion that biological control methods for the eradication of this insect be implemented immediately at Bahia Urvina in order to prevent the future spread of $I$. purchasi to the virgin coast of Fernandina.

The state of most populations of $D$. tenuifolius appears to be healthy, although a few populations have died back significantly over the past few years due to scale insect 
infestation on three separate islands (Pinta, Santa Cruz, and Isabela). Again, if put into effect in the near future, biological controls may be able to reverse these effects and ensure a healthy future for this species. The third species of the genus, D. alternifolius, is at the greatest risk of extinction and I recommend rapid ex situ reproduction and germination studies in order to facilitate the prompt reintroduction of this species to its two native habitats. A thorough collection of seeds should also be made at each site as soon as possible, to protect the genetic variation of this species for future generations. Finally, I also recommend that similar studies be performed on the species of Darwiniothamnus that once inhabited Pinzon, so that a reintroduction plan can be implemented for this island as soon as possible.

In regards to question \#2: my two-month field research and preliminary herbarium studies suggest that a new subspecies of $D$. tenuifolius may be recognized from Pinta and Santiago; however, a detailed morphological analysis of all specimens collected from these areas will have to be completed before any new subspecies or varieties are documented. There also may be a few of hybrid populations on the island of Isabela that warrant recognition as varieties; however, further population-based studies are needed before these recommendations can be finalized.

In regards to question \#3: the greatest biological threats on the existing populations of Darwiniothamnus are introduced animal species (such as feral pigs, goats, and cattle) and the lethal scale insect, I. purchasi. I therefore recommend that biological control methods for each of these pests be introduced to all of the vulnerable populations of Darwiniothamnus as soon as possible. The areas that warrant the most concern are Los Gemellos, on the island of Santa Cruz, the areas surrounding Cartago Bay, Volcan 
Alcedo and Bahia Urvina on the island of Isabela, and the area surrounding both trails up to peak of Pinta. I also recommend that fences be put around the existing populations of D. alternifolius both on Volcan Sierra Negra and Cerro Azul, in order to protect them from extirpation by feral animals. In addition, because the 1985 fire on Volcán Sierra Negra nearly wiped out the entire population $D$. alternifolius at this location, I would make certain that residents from the town of Puerto Villamil, at the base of Volcán Sierra Negra, are aware of the danger that accidental fires may have on the native flora of the Galápagos.

In response to question \#4: the inquiry of why members of Darwiniothamnus only grow in certain areas or islands is perhaps the hardest to answer. Because I have seen members of this genus range from humid coastlines, to sun-scorched lava fields, to high elevation savannahs of very low temperatures and ultimately to the inside of craters with sulpher plumes and both hot and freezing winds, I do not believe that climate is a limiting factor. The soil data I collected, although it contains some interesting correlations, does not seem to point to any one conclusive answer either. A trend was evident at one location near Volcan Ecuador, which lacked several of the elements and micronutrients necessary for the successful growth of most plants, and which interestingly was also void of any species of Darwiniothamnus.

Finally, my fifth question, which assessed the monophyly of Darwiniothamnus and what geographical area appears to be its source of origin, produced perhaps the most surprising results of the thesis. As discussed in Chapter 4, the genus is not monophyletic, but polyphyletic, and stems from two separate introductions into the Galápagos Islands. 
The sister taxon to $D$. tenuifolius and $D$. lancifolius, E. bellidiastroides, is an endemic from the island of Cuba, further corroborating recent biogeographical hypotheses linking the biota of the Caribbean basin with the Galápagos Islands (e.g. Porter, 1979; Sato et al., 2001; Wiggins, 1966; Eliasson, 1996; Grehan, 2001). The sister taxa to the third species of Darwiniothamnus, D. alternifolius, were just as Harling (1962) suggested, namely, E. fasciculatus and E. luxurians of the central coast of Chile. Furthermore, due to the results of this paper, it is the suggestion of the author that Darwiniothamnus be regrouped within the paraphyletic Erigeron-Conyza complex, until further taxonomical work is done on the group to clarify its subgeneric relationships. 


\section{Nomenclatural conclusions:}

Erigeron alternifolius (Lawesson \& Adsersen) Andrus comb. nov.

Basionym: Darwiniothamnus alternifolius Lawesson \& Adsersen

Notes on the endemic genus Darwiniothamnus Harling (Asteraceae, Astereae) from the Galápagos Islands. Op. Bot. 92:7-15 (1987).

Type: Lawesson, Adsersen, Nowak, Velasco, Abodrabbo \& Tupiza 2452. (holotype

QCA, isotypes C, CDS (= Erigeron alternifolius (Law.Ads) Andrus))

Darwiniothamnus tenuifolius (Hooker fil.) Harling (1962)!

Erigeron tenuifolius Hooker (1847)

Type: Darwin s. num. (CGE) (probably collected on Floreana)!

D. tenuifolius ssp. santacruzianus Harling (1962)!

Type: Harling $5076(\mathrm{~S})$ !

Darwiniothamnus lancifolius (Hooker fil.) Harling (1962)!

Erigeron lancifolius Hooker (1847)

Type: Darwin s.num. (CGE) (probably collected at Tagus Cove, Volcan Darwin)!

Erigeron tenuifolius ssp. lancifolius (Hook. f.) Solbrig (1962)

D. lancifolius ssp. glabriusculus (Stewart) Lawesson \& Adsersen (1987)!

Erigeron lancifolius var. glabriusculus Stewart (1911)

Type: Stewart $724(\mathrm{GH})$ from Sierra Negra!

Darwiniothamnus tenuifolius var. glabriusculus (Stewart) Cronquist (1970).

D. lancifolius ssp. glandulosus Harling (1962)!

Darwiniothamnus tenuifolius var. glandulosus (Harling) Cronquist (1970)

Type: Harling 5376 (S) from Volcan Darwin! 
Table 4.1: Voucher list for all species used in this study, includes GPS and geographical data. (Note: all species with accession numbers listed as "recently submitted" were sequenced by the author).

\section{Taxon}

1. Aphanosstephus ramosissimus DC

2. Aphanosstephus skirrhobasis DC. Trek.

3. Aster amellus L.

4. Chiliotrichum rosmarinifolium

5. Chrysopsis gossypina (Michx.) Ell.

6. Conyza borariensis (L.) Cronq.

7. Conyza canadensis (L.) Cronq.

8. Darwiniothammus alternifolius Lawesson \& Adsersen

9. Darwiniothammus alternifolius Lawesson \& Adsersen

10. Darwiniothammus tenuifolius (Hook. f.) Harling

11. Darwiniothmanus lancefolius ssp. glandulosus Harling

12. Darwiniothmanus tenuifolius (Hook. f.) Harling

13. Darwiniothamnus lancefolius glabriusculus (Stewart) L \& A

14. Erigeron arenarioides (D.C. Eaton) Rydb.

15. Erigeron argentatus A. Gray

16. Erigeron bellidiastroides Griesb.

17. Erigeron bellioides DC.

18. Erigeron coronarius E. Greene

19. Erigeron cunefolius DC.

20. Erigeron dissectus Urban

21. Erigeron dryophyllus A. Gray

22. Erigeron ecuadoriensis

23. Erigeron fasciculatus Colla *

24. Erigeron fasciculatus Colla *

25. Erigeron fernandezianus (Colla) Solbrig

26. Erigeron gradiflorus Hook.

27. Erigeron jamaicensis L.

28. Erigeron sp.

29. Erigeron luxurians (Skottsb) Solbrig **

30. Erigeron maximus (D. Don) DC.

31. Erigeron podphyllius Nesom

32. Erigeron philadelphicus $L$.

33. Erigeron pinnatisectus (A. Gray) A. Nels

34. Erigeron pinnatus Turcz.

35. Erigeron pygmaeus (A. Gray) E. Greene

36. Erigeron quercifolius Lam.

37. Erigeron rosulatus Wedd.

38. Erigeron longipes DC

39. Erigeron socorrensis I.M. Johnston

40. Erigeron stanfordii I.M. Johnston ex Nesom

41. Erigeron subalpinus

42. Erigeron tenuis Torr. And A. Gray

43. Erigeron thrincioides Griesb.

44. Erigeron tweedyi Canby

45. Erigeron uniflorus $L$.

46. Erigeron ursinus D. C. Eaton

47. Erigeron veracruzensis Nesom

48. Hetertheca villosa (Pursh) Shinners

49. Kalimeris integrifolia Turcz. Ex DC

50. Nardophyllum bryoides

51. Nardophylum obtusifolium

52. Oritrophium hieracioides (Wedd.) Cuatr.

53. Pteronia incana (Burm.) DC.

54. . Regiopappus leptocladus A. Gray
Voucher Origin / Collector \& coll.\#

E. Ventura 7924 (MO)

A. Brant 1974 (MO)

A.K. Skvortsov s.n. (MO)

M. Bonifacino (\#191) D. Gutierrez \& P. Simon (LPS)

M. Merello 416 (MO)

R. D. Noyes $1182(\mathrm{ND})$

C. Ochs $248(\mathrm{MO})$

N. Andrus, 16.7/ND (FTG)

N. Andrus, 16.9/ND (FTG)

A Tye $4 / 25 / 00$ (CDS)

N. Andrus, 7.1/3.1 (FTG/CDS)

N. Andrus, 5.1/81.1 (FTG/CDS)

N. Andrus, 10.2/67.2 (FTG/CDS)

J.S. Tuhy 3619 (MO)

M. A. Franklin 7062 (MO)

A. Urquiola, 820 (HPPR)

C. Taylor $11705(\mathrm{MO})$

R. M. King 9896 (MO)

P. Herrera (HAC)

Jimenez, Peguero \& Francisco-Ortega 3/01 (FTG/JBSD)

G. B. Hinton 17777 (MO)

loan from Ximenna Aguire (QCNE)

ITS1: B. Sparre 2913 (S)

ITS2: C. Marticorena et al 9788 (CONC)

T. Stuessy 11441 (OS)

R. Hartman 55581 (RM)

Zanoni et al. , \# 477598 (JBSD)

Escobedo $\# 305$ (LL)

P. Jorge 1759 (S)

R. Wasum 8044 (MO)

G. Nesom $5438(\mathrm{MO})$

R.D. Noyes 1165 (IND)

R.D. Noyes 1146 (IND)

B. Lojtnant $13865(\mathrm{MO})$

K. Ake 215 (MO)

S. Hill $17962(\mathrm{MO})$

T. Steussy 8508 (OS)

G. Carmona 800 (GCD)

R. Moran, \#25455 (LL)

M. Martinez, \#1725 (LL)

material sent by D. Castillo; \#23179 \& 08110 (JBSD)

G. Nesom 7224 (MO)

R. Oviedo and E. Gamboa 8/18/00 (HAC)

J. Grimes 2243 (MO)

R. D. Noyes 1190 (IND)

L.M. Schultz 3711 (MO)

G. Nesom 5945 (MO)

B. Stein $1823(\mathrm{MO})$

W. Wei $6003(\mathrm{MO})$

M. Bonifacino 304 \& V. Romano (LPS)

M. Bonifacino 298 \& V. Romano (LPS)

J. C. Solomon 16570 (MO)

H. Joffe 850 (MO)

A. Tiehm 11753 (MO) 
Table 4.1 cont.

No. GenBank Accession number / Exact collection site, if available

1 AF046990; Mexico: Guanajuato

2 AF118521; USA: Texas

3 AF046961; Russia: N. Caucasus

4 Argentina: Paso Pino Hachado near Chilean border; 3839.738 S: 70 53.00, 1/16/00 (recently submitted genbank acc. \#: AF511590)

5 AF046993; USA: South Carolina

6AF118513; USA: Alabama

7 AF046987; USA: Missouri

8 Galapagos Islands, Isla de Isabela, Volcan Sierra Negra, $0050.26 \mathrm{~S}, 09110.57 \mathrm{~W}$ (recently submitted genbank acc. \#: AF511573)

9 Galapagos Is., Isla de Isabela, Volcan Sierra Negra, $0050.26 \mathrm{~S}, 09110.57 \mathrm{~W}$ (recently submitted genbank acc. \#: AF511575)

10 Galapagos Is., Isla de Santiago $0019.52 \mathrm{~S}$ and $9846.23 \mathrm{~W}$ (recently submitted genbank accession number: AF511576)

11 Galapagos Is., Isla de Isabela, Volcan Darwin, $0014.96 \mathrm{~S}$, $9121.92 \mathrm{~W}$ (recently submitted genbank accession \#: AF511574)

12 Galapagos Is., Isla de Pinta, on trail up volcano, $0034.63 \mathrm{~N}, 09045.12 \mathrm{~W}$ (recently submitted genbank acc. \#: AF511578)

13 Galapagos Is., Isla de Isabela, Volcan Sierra Negra, $0050.37 \mathrm{~S}, 09106.24 \mathrm{~W}$ (recently submitted genbank accession \#: AF511577)

14 AF118528; USA: Utah

15 AF118506; USA: Utah

16 Cuba, Laguna Vieja, Santa Teresa, Pinar del Rio (recently sub. genbank acc.: \#AF511580)

17 Puerto Rico: Rio Grande (recently submitted genbank accession \#: AF511588)

18 AF118520; Mexico: Chihuahua

19 Cuba; Brook near Hotel Colonial on Juventud Island, 12/10/00 (recently submitted genbank accession \#: AF511583)

20 Dominican Republic, collected in Prov. San Cristobal $18^{\circ} 28^{\prime} \mathrm{N}, 70^{\circ} 14^{\prime} \mathrm{W}$ (recently submitted genbank acc.: \# AF511581)

21 AF118524; Mexico: Nuevo Leon

22 Ecuador; Herbario Nacional de Quito (QCNE) (recently submitted genbank accession \#: AF511584)

23 Chile, near Los Vilos ( $3158.0 \mathrm{~S}$ and $7129.0 \mathrm{~W}$ ) (recently submitted to genbank, pending number)

24 Chile, near Los Vilos ( $3158.0 \mathrm{~S}$ and $7129.0 \mathrm{~W}$ ) (recently submitted to genbank, pending number)

25 AF118515; Chile: Juan Fernandez Island

26 AF118494; USA: Wyoming

27 Dominican Republic, Cordillera central. Jardin Botanico in Santo Domingo

28 Mexico: Michoacan; 10/3/85 (recently submitted genbank accession number: AF511589)

29 Chile, coast north of Santiago (recently submitted genbank accession number: AF511582)

30 AF118509; Brazil: Rio Grande do Sul

31 AF118542; Mexico: Chihuahua

32 AF046989; USA: Indiana

33 AF118501; USA: Wyoming

34 AF118517; Ecuador: Cotopaxi

35 AF118526; USA: California

36 AF118525; USA: South Carolina

37 AF118516; Chile; Juan Fernandez Island

38 Mexico; Xalapa, (recently submitted genbank accession number: AF511579)

39 Socorro Island; 4/18/78, plant abundant from sea cliffs to shrubby slopes (recently submitted genbank accession \#: AF511587)

40 Mexico: Tamaulipas; $4 / 27 / 88$, (recently submitted genbank accession number: AF511585)

41 Dominican Republic, no exact location was given

42 AF118488; USA: Texas

43 Cuba, Pinar del Rio, on river bank before reaching the waterfall (recently submitted genbank acc \#: AF511586)

44 AF118529; USA: Montana

45 AF046988; Conservatoire et Jardins Botaniques de Nancy "1401", Villers les Nancy, France, ex Sweeden

46 AF118491; USA: Wyoming

47 AF118523; Mexico: Tamaulipas

48 AF046994; USA: Colorado

49 AF046960; China: Jiangsu

50 Argentina: Santa Cruz province, near El Chalten, 2/10/00 (recently submitted genbank accession number: AF511591)

51 Argentina: Chubut province, on Route 40; lat: 4243.56 S, long: 7104.03 W., 2/2/00 (recently submitted genbank acc. \# AF511592)

52 AF046946; Bolivia: La Paz

53 AF046947; South Africa: Cape

54 AF046971; USA: California 


\section{Table 4.1 cont.}

\section{No. Geographic Distribution}

1 SW US and Mexico

2 SW US and Mexico, mostly in Texas

3 Northern Hemisphere

4 South America

5 South Eastern USA

6 South America, introduced throughout North America

7 North America

8 Galapagos Islands, southern tip of Isabela, on Cerro Azul and Volcan Sierra Negra

9 Galapagos Islands, southern tip of Isabela, on Cerro Azul and Volcan Sierra Negra

10 Galapagos Islands, Isabela, Fernandina, Santa Cruz, Santiago, Floreana and Pinta

11 Galapagos Islands, Fernandina and Isabela

12 Galapagos Islands, Isabela, Fernandina, Santa Cruz, Santiago, Floreana and Pinta

13 Galapagos Islands, Isabela only

14 Western US, especially in Utah and Nevada

15 Western US, especially in Utah, Nevada and California

16 Cuba

Abundant in the Dominican Republic, Puerto Rico \& Cuba; but rare in Haiti, Vieques and the

17 Bahamas

18 Mexico

19 Puerto Rico, West Indies, Central America from Guatemala to Panama, rare in Mexico

20 Hispañiola

21 Mexico

22 Higher elevations of Ecuador

23 Chile, typically north of Santiago

24 Chile, typically north of Santiago

25 Juan Fernandez Islands

26 Western USA from CA to AK and out to WY

27 Puerto Rico, Greater Antilles, Hispañiola, Central America

28 Mexico and Central America

29 Chile

30 Brazil and Paraguay

31 Centeral and Western Mexico

32 Central USA, especially in Indiana and Colorado

33 Western USA, especially in Colorado, Wyoming, and New Mexico

34 Highlands of Ecuador

35 Western USA, especially California and Nevada

36 SE USA and the West Indies

37 Bolivia, Peru, Juan Fernandez Islands and Chile

38 Mexico and Central America

39 Isla Socorro, Revillagigedo Islands

40 Mexico, extending to Central America

41 Dominican Republic

42 SW USA

43 Cuba

44 midwest USA, especially MT, WY, ID

$45 \mathrm{~N}$. America = lectotype for Erigeron

46 Western U.S.A.

47 Mid-northern Mexico only

48 Western USA and Mexico 
49 Central, East and SE Asia

50 South America, especially Bolivia, Argentina and Chile

51 South America, especially Bolivia, Argentina and Chile

52 Along the Andes from Venezuela and Colomia to Peru and Bolivia; 1 species in Mexico

53 Southern Africa

54 Mexico, southwestern USA 
Figure 4.1: Results of the phylogentic study of Darwiniothamnus:

(bootstrap values are indicated in red, branch lengths are in blue, all taxa of Darwiniothamnus included in this study are highlighted in green, and the seven groups discussed in Chapter 4 are depicted in purple.)

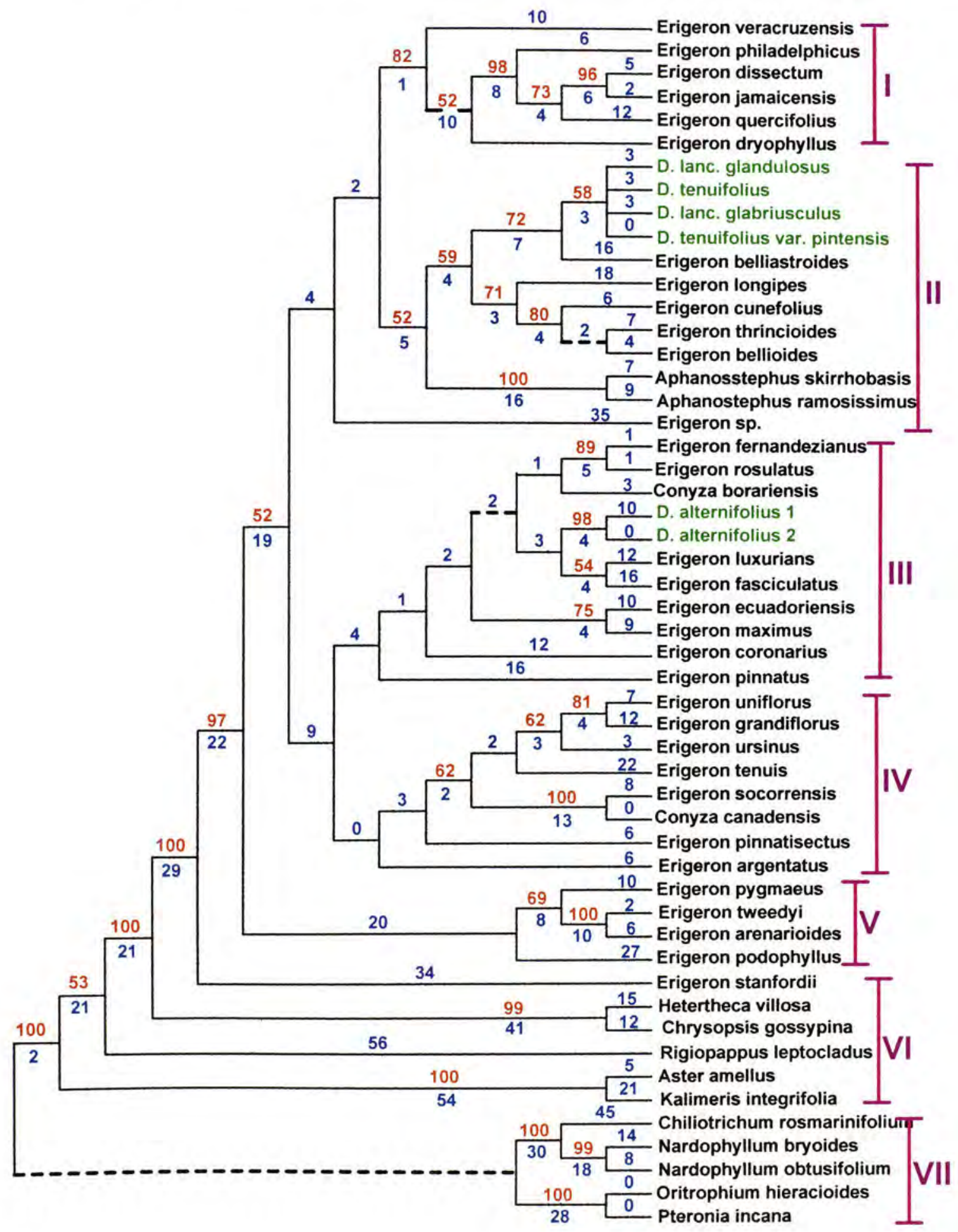


Figure 4.2: Phylogeny showing the ancestral areas for all taxa included in this study.

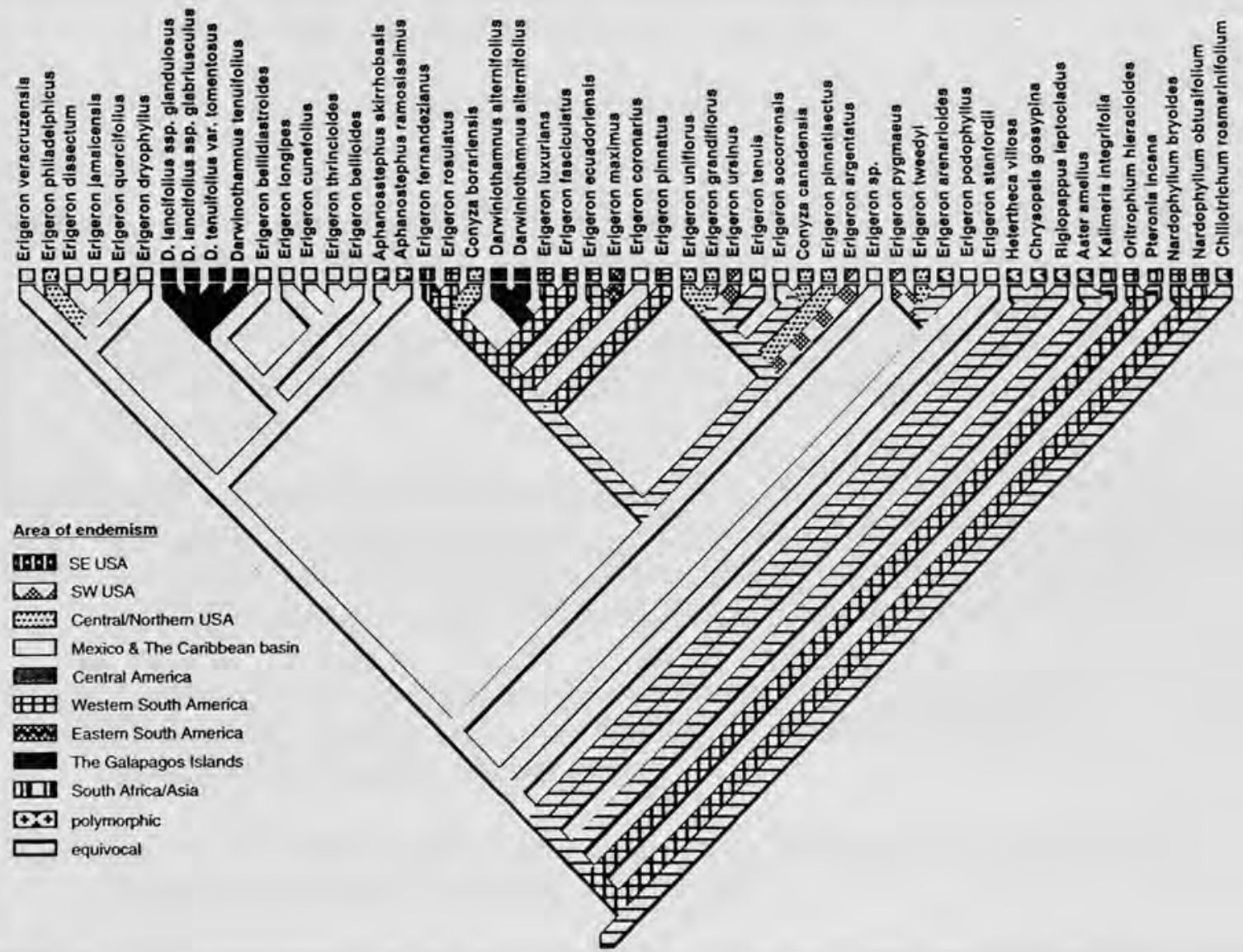




\section{REFERENCES}

Adams, C. D. 1972. Flowering plants of Jamaica. University of the West Indies, Jamaica; Robert MacLehose and Company Limited, The University Press: Glasgow.

Alain, H. 1962. Flora de Cuba V. (ed. E. E. Liogier) Editorial Universitaria, Universidad de Puerto Rico, Rio Piedras, Puerto Rico.

Andersson, N.J. 1857. Om Galápagos Oarnes Vegetation. Kongl. Svensk. Vet. Akad. Handl. 1857: 1-114

Baagoe, J. 1978. Taxonomical application of ligule microcharacters in Compositae, I: Anthemideae, Heliantheae, and Tageteae. Bot. Tid. 71: 193-223.

Baldwin, B.G. 1992. Phylogenetic utility of the Internal Transcribed Spacers of nuclear ribosomal DNA in plants: and example from the Compositae. Molec. Phy. \& Evol. 1: 3-16.

Baldwin, B.G.; Crawford, D.J.; Francisco-Ortega, J.; Kim, S.-C.; Sang, T, and Stuessy, T.F. 1998. Molecular phylogenetic insights on the origin and evolution of oceanic island plants. In: Molecular systematics of plants II: DNA sequencing. (D.E. Soltis, P.S. Soltis, J.J. Doyle, eds.). Kluwer Academic, Boston. Pp. 410-441.

Bogler, David. 2001. Plant Molecular Systematic Lab Protocols. For use in the Molecular Systematics Laboratory Fairchild Tropical Garden/Florida International University. Unpublished.

Botschantzev, V. P. 1959. Erigeron. In: Komarov V.L. (ed) Flora U.R.S.S., U.S.S.R. Academy of Sciences, Leningrad, pp. 191-288.

Bremer, K. 1987. Tribal interrelationships of the Asteraceae. Cladistics 3: 210-253.

Bremer, K. 1994. Asteraceae, cladistics and classification. Portland, Oregon: Timber Press.

Carlquist, S. 1965. Island Life. New York: The Natural History Press.

Carlquist, S. 1974. Island Biology. Columbia University Press, New York and London.

Carr, G. 1998. Another new species of Dubautia (Asteraceae-Madinnae) from Kaua'I, Hawaiian Islands. Novon 8: 8-11. 
Clevinger, J. and Panero, J. 2000. Phylogenetic analysis of Silphium and subtribe Engelmanniinae (Asteraceae: Heliantheae) based on ITS and ETS sequence data. $A B J .87:$ 565-572.

Correll, D. and Correll, H. 1982. Flora of the Bahama Archipelago. (ed.: J. Cramer) A. R. Gantner Verlag KG, Germany.

Crawford, D. and Stuessy, T. 1987. Allozyme divergence and the evolusion of Dendroseris (Compositae: Lactuceae) on the Juan Fernandez Islands. Sys. Bot. 12: 435-443.

Crawford, et al. 1992. Allozyme diversity within and divergence among four species of Robinsonia (Asteraceae: Senecioneae), a genus endemic to the Juan Fernandez Islands, Chile. $A J B$ 79:962-966.

Cronquist, A. 1947. Revision of the North American species of Erigeron, north of Mexico. Brittonia. 6: 121-302.

Cronquist, A. 1970. New combinations in the Compositae of the Galápagos Islands. Madrono 20: 255-256.

Cronquist, A. 1971. Compositae. - In :Wiggins, I.R. and Porter, D. M. (eds.) Flora of the Galápagos Islands. Stanford University Press, Stanford, pp. 300-367.

Downie, S. and Katz-Downie, D. 1996. A molecular phylogeny of Apiaceae subfamily Apioideae: Evidence from Nuclear Ribosomal DNA Internal Transcribed Spacer sequences. $A B J .83: 234-251$.

Downie, S. et al. 2000. Molecular systematics of Old World Apioideae (Apiaceae): relationships among some members of tribe Peucedaneae sensu lato, the placement of several island-endemic species, and resolution within the apioid superclade. Can. J. Bot. 78: 506-528.

Doyle, J. and Doyle, J. 1987. A rapid DNA isolation procedure for small quantities of fresh leaf tissue. Phyto. Bull. 19: 11-15.

Eliasson, U.H. 1996. Portulacaceae. In G. Harling \& L. Andersson Flora of Ecuador 55: 29-53. Nordic Council for Publications in Botany, Copenhagen.

Farris, J. 1989. The retention index and homoplasy excess. Syst. Zool. 38: 406-407.

Francisco-Ortega, J. et al. 1999. Internal transcribed spacer sequence phylogeny of Crambe L. (Brassicaceae): molecular data reveal two old world disjunctions. Molec. Phylogen. Evol. 11: 361-380. 
Francisco-Ortega, J. et al. 2001a. Origin and evolution of Argyranthemum (Asteraceae: Anthemideae) in Macaronesia. In: T. Givnish and K. Sytsma (eds.), Molecular evolution and adaptive radiation. Cabridge University Press, Cambridge, UK. 407-431.

Francisco-Ortega, J. et al. 2001b. Origin and evolution of the endemic Macaronesian Inuleae (Asteraceae): Evidence from the internal transcribed spacers of nuclear ribosomal DNA. Biol. Jour. Linn. Soc. 72:332-342.

Gilbert, D. 1993. Seqapp@Bio.indiana.edu or via fttp.bio.Indiana.edu/molbio/seqapp.

Givnish, T. and Sytsma, K. 1997. Molecular Evolution and Adaptive Radiation Cambridge: Cambridge University Press.

Good, R. 1964. Geography of Flowering Plants. New York, NY: John Wiley and Sons.

Grehan, J. Biogeography and evolution of the Galápagos: integration of the biological and geological evidence. Bio. J. Linn. Soc. 74: 267-287.

Grau, J. 1977. Astereae - Systematic review. In the Biology and Chemistry of the Compositae, vol. 1. Eds. V.H. Heywood, J. B. Harborne, and B.L. Turner. London: Academic Press. Pp. 539-565.

Halliday, G. 1976. Erigeron. In Tutin, T. G., Heywood, V. H., Burges, N. A., Moore, D. M., Valentine, D. H., Walters, S. M. Webb, D. A., (eds.) Flora Europaea. Vol. 4. Plantaginaceae to Compositae (and Rubiaceae). Cambridge University Press, Cambridge. Pp. 116-120.

Harling, G. 1962. On some Compositae endemic to the Galápagos Islands. Acta Hort. Bergiana 20: 63-120.

Hertz, W. 1977. Sesquiterpene lactones in the Compositae. In the Biology and Chemistry of the Compositae, vol. 1. Eds. V.H. Heywood, J. B. Harborne, and B.L. Turner. London: Academic Press. Pp. 337-357.

Hooker, J. D. 1847. On the Vegetation of the Galápagos Archipelago, as compared with that of some other Tropical Islands and of the Continent of America. Trans. Linn. Soc. 20: 235-262.

Johnston, I. 1931. The flora of the Revillagigedo Islands. PCAS 20: 9-104.

Jones, A. 1976. Observations on the shape and exposure of style branches in the Astereae (Compositae). AJB 63:259-262. 
Kishino, H. and Hasegawa, M. 1989. Evaluation of the maximum likelihood estimate of the evolutionary tree topologies from DNA sequence data, and the branching order in Hominoidea. J. Molec. Evol. 29: 170-179.

Kluge, A.G. and Farris, J.S. 1969. Quantitative phyletics and the evolution of anurans. Syst. Zool. 18:1-32.

Kornkven, A., Watson, L. and Estes, J. 1998. Phylogenetic analysis of Artesmia section Tridentatae (Asteraceae) based on sequences from the Internal Transcribed Spacers (ITS) of Nuclear Ribosomal DNA. AJB. 85: 1787-1795.

Lawesson, J.E. and Adsersen, H. 1987. Notes on the endemic genus Darwiniothamnus Harling (Asteraceae, Astereae) from the Galápagos Islands. Op. Bot. 92:7-15.

Lewis, C. E. and Doyle, J. J. 2001. Phylogenetic utility of the nuclear gene malate synthase in the palm family (Arecaceae). Molec. Phylo. \& Evo. 19: 409-420.

Lowe, A. and Abbott, R. 1996. Origins of the new allopolyploid species Senecio cambrensis (Asteraceae) and its relationship to the Canary Islands endemic Senecio teneriffae. AJB 83: 1365-1372.

Maddison, D. \& Maddison, W. MacClade, version 4.03. clade@arizona.edu

Moller, M. and Cronk, Q. 1997. Origin and relationships of Saintpaulia (Gesneriaceae) based on ribosomal DNA Internal Transcribed Spacer (ITS) sequences. $A J B$ 84: 956-965.

Morgan, D. and Simpson, B. 1992. A systematic study of Machaeranthera (Asteraceae) and related groups using restriction site analysis of cpDNA. Sys. Bot. 17: 511-531.

Nesom, G. 1989. Infrageneric taxonomy of New World Erigeron (Compositae: Astereae). Phytologia 67: 67-93.

Nesom, G. 1990. Taxonomy of the Erigeron coronaries group of Erigeron sect. Geniculactis (Asteraceae: Astereae). Phytologia. 69: 237-253.

Nesom, G. 1994. Subtribal classification of the Astereae (Asteraceae). Phytologia. 76: 193-274.

Noyes, R. and Rieseberg, L. 1999. ITS sequence data support a single origin for north American Astereae (Asteraceae) and reflect deep geographical divisions in Aster s.l. $A J B$ 86: $398-412$.

Noyes, R. 2000. Biogeographical and evolutionary insights on Erigeron and allies (Asteraceae) from ITS sequence data. Plant Syst. Evol. 220: 93-114. 
Perry, R. 1984. The Islands and Their History. In Perry, R. (ed.), Key environments. Galápagos . Pergamon press, Oxford. 101-114.

Porter, D. M. 1976. Geography and dispersal of Galápagos Islands vascular plants. Nature, Lond. 264: 745-746.

Porter, D.M. 1979. Endemism and evolution in Galápagos Islands vascular plants. In: Plants and Islands. D. Bramwell, ed. pp. 225-226.

Porter, D. M. 1983. Vascular plants of the Galápagos: origin and dispersal. In: Patterns of Evolution in Galápagos Organisms. Eds. R. J. Bowmann, M. Berson \& A. E. Leviton. Pacific Division, AAAS. San Francisco, pp. 33-96.

Robinson, B. L. 1902. Flora of the Galápagos Islands. Proc. Amer. Acad. 38:78-270.

Robinson, B. L. and Greenman, J.M.. 1895. On the flora of the Galápagos Islands as shown by the collections of Dr. Baur. Am. J. Sci. 50: 135-149.

Sanders, R. et al. 1987. Phytogeography and evolution of Dendroseris and Robinsonia, tree-Compositae of the Juan Fernandez Islands. Op. Bot. 92: 195-215.

Sanderson, M. J. and Doyle, J. J. 1992. Reconstruction of organismal and gene phylogenies from data on multigene families: Concerted evolution, homoplasy, and confidence. Syst. Biol.

Sato, A. et al. 2001. On the origin of Darwin's Finches. Mol. Biol. Evol. 18: 299-311.

Seaman, F. C. 1982. Sesquiterpene lactones as taxonomical characters in the Asteraceae. Bot. Rev. 48: 121-595.

Schilling, E. et al. 1994. Evidence from chloroplast DNA restriction site analysis on the relationships of Scalesia (Asteraceae: Heliantheae). AJB 81: 248-254.

Simmons, M. and Ochoterena, H. 2000. Gaps as Characters in Sequence-Based Phylogenetic Analyses. Syst. Biol. 49(2): 369-381.

Skottsberg, C. 1922. The phanerogams of the Juan Fernandez Islaneds. Nat Hist. Juan Fernandez and Easter Is. 2: 95-240.

Solbrig, O. 1960. The South American sections of Erigeron and their relation to Celmisia. Cont. of Gray Herb. 188: 65-85.

Solbrig, O. 1962. The South American species of Erigeron. Cont. of Gray Herb. 191: 379. 
Solbrig, O., Anderson, L., Kyhos, D. and Raven, P. 1969. Chromosome numbers in Compositae, VII Astereae III. AJB 56: 348-353.

Soltis, D., Soltis, P, and Doyle, J. 1998. Molecular Systematics of Plants II, DNA sequencing. Norwell, MA: Kluwer Academic Publishers.

Stewart, Alban. 1911. Expedition of the California Academy of Sciences to the Galápagos Islands 1905-1906. A botanical survey of the Galápagos Islands. Cal Academy Press. San Francisco, California.

Suh, Y. and Simpson, B. 1990. Phylogenetic analysis of chloroplast DNA in North American Gutierrezia and related genera (Asteraceae: Astereae). Sys. Bot. 15: 660-670.

Svenson, H.K. 1935. Plants of the Astor Expedition, 1930 (Galápagos and Cocos Islands). $A J B$ 22: 208-277.

Svenson, H. 1946. Vegetation of the coast of Ecuador and Peru and its relation to the Galápagos Islands. AJB. 33: 394-426.

Swofford, D. 1990. Paup*, version 4.0. Sunderland, MA: Sinaur Ass. Publishing.

Swofford, D. and Olsen, G. 1990. Phylogeny reconstruction. In "Molecular Systematics" eds. D. Hillis and C. Moritz. Sinauer, Sunderland. Pp. 411-501.

Takhtajan, A. 1988. Floristic Regions of the World. Dehra Dun, India: Bishen Singh Mahendra Pal Singh.

Templeton, A. 1983. Phylogenetic inference from restriction endonuclease cleavage site maps with particular reference to the humans and apes. Evolution 31: 221-224.

Thompson, J. D., et al. 1997. The Clustal X windows interface: flexible strategies for multiple sequence alignment aided by quality analysis tools. Nucl. Acids. Res. 24: 4876-4882.

Thompson, J. D., F. Plewniak and O. Poch. 1999. A comprehensive comparison of multiple sequence alignment programs. Nuc. Acid. Res. 27:2682-2690.

Torrell, M. et al. 1999. Phylogeny in Artesmisia (Asteraceae: Anthemideae) inferred from nuclear ribosomal DNA (ITS) sequences. Taxon. 11: 721-736.

Valdebenito, H., Stuessy, T., and Crawford, D. 1992. Evolution of Erigeron (Compositae) in the Juan Fernandez Islands, Chile. Sys. Bot. 17: 470-480. 
Valdebenito, H. et al. 1990. A new biogeographic connection between islands in the Atlantic and Pacific Oceans. Nature. 347: 549-550.

Vargas, P. et al. 1998. Nuclear ribosomal DNA evidence for a western North American origin of Hawaiian and South American species of Sanicula (Apiaceae). Proc. Nat. Acad. Sci. 95: 235-240.

Wem-Hsiung, L. 1997. Molecular Evolution. Sunderland, MA: Sinauer Associates.

White, T. et al. 1990. Amplification and direct sequencing of fungal ribosomal RNA genes for phylogenetics. In: Innis, M., Gelfand, D. Sninsky, J and White, T. (eds.), PCR Protocols. A Guide to Methods and Applications. Academic Press, San Diego.

Whittaker, R. 1998. Island Biogeography: Ecology, Evolution and Conservation. Oxford University Press, New York.

Wiggins, I. 1966. Origins and Relationships of the Flora of the Galápagos Islands. In: The Galápagos Proc. Symp. GISP. Ed. R. I. Bowman. Pp. 175-182.

Wild, H. 1969. The genus Nidorella Cass. Bol. Soc. Brot. 43: 209-243.

Zhang, X. and Bremer, K. 1993. A cladistic analysis of the tribe Astereae (Asteraceae) with notes on their evolution and subribal classification. Plt. Sys. Evol. 184: 259283. 
APPENDIX 1a: A list adapted from Porter $(1979 \&$ 1983) of all the species from within the Asteraceae family on the Galápagos Islands. Included in this list, in order, are the names of the taxa, authors and dates of publication, their distributions by island, habitat types, chromosome numbers, discussions of their relationships, modes of dispersal and probable origin where possible. Introduced species are marked with a dash $(-)$, native species are marked with a $\left({ }^{\wedge}-\right)$ and endemic species are marked with an asterix $\left({ }^{*}-\right)$

Note the following abbreviations are used for each island: $\mathbf{S a C}=$ Santa Cruz, $\mathbf{S a M}=$ Santa Maria, $\mathbf{S C}=$ San Cristobal, $\mathbf{I}=$ Isabela, $\mathbf{F}=$ Floreana, $\mathbf{B a l}=$ Baltra, Bar $=$ Bartolome, Esp $($ Gar $)=$ Espanola Pta $=$ Pinta, $\mathbf{P z n}=$ Pinzon, $\mathbf{R}=$ Rabida, and $\mathbf{S}=$ Santiago.

-Acanthospermum microcarpum Robins. introduced weed; Andean. -Adenostemma platyphyllum Cass. (as A. lavenia (L.) Kuntze; King \& Robinson 1975) introduced weed; Andean.

-Ageratum conyzoides L. ssp. conyzoides, introduced weed, pantropical, originally from tropical America.

-A. conyzoides ssp. latifolium (Cav.) M.F. Johnson (Johnson, 1971) introduced weed (1835) tropical America.

-Ambrosia artemisiifolia L. introduced weed, pantropical, originally from the New World.

*-Baccharis steetzii Anderss. - I, SaC, SaM, SC; Scalesia Zone. Probably related most closely to the Andean (Ecuador) B. gnidiifolia HBK., which also occurs in the Galápagos.

$\wedge-B$. gnidiifolia HBK. Andean (Ecuador), dispersed by wind (has a pappus with achenes 2-3 mm long).

- Bidens cynapiifolia HBK. Introduced weed, tropical America origin and distribution. -B. pilosa L. introduced weed; pantropical distribution, originally from the Caribbean. $\wedge$-B. riparia HBK. Tropical America (Mexico to Peru and Brazil). Dispersed by birds externally (achenes are 10-15 mm long with a pappus of 3-5 retrorsely-barbed awns). $\wedge$-Blainvillea dichotoma (Murr.) Stewart, pantropical distribution, dispersed by birds externally (achenes 2-3.5 mm long, pappus awns 0.5-1.5 mm long, hirtellous).

-Brickellia diffusa (M. Vahl) A. Gray, introduced weed, tropical America origin and distribution.

*-Chrysanthellum pusillum Hook.f. - F, I, SaC, SaF, SaM, SC, SS; Arid and Transition Zones. Most closely related to $C$. mexicanum Green. from south-central Mexico (see Duncan, 1979), although Eliasson (1972) has argued for the recognition of $C$. fagerlindii Eliass. as a separate taxon, it is best included under C. pusillum (see Duncan, 1979), as was done by Conquist (in Wiggins and Porter, 1971), dispersed by birds externally (achenes 1-2 mm long, irregularly tuberculate). 
-Conyza bonariensis (L.) Cronq., introduced weed, pantropical distribution, originally from tropical America.

*-Darwiniothamnus. Currently considered to be an endemic genus, for which Cronquist (in Wiggins and Porter, 1971) recognized one species with three varieties. Harling's (1962) treatment is followed below which up until now most accurately represented the populations in the field. Included is a third species described by Lawesson and Adsersen (1987) which after the results of this paper may no longer be considered as part of the same group. The genus is most closely related to Erigeron. And as previously stated by Harling: "The nearest relatives of Darwiniothamnus within Erigeron, as this genus is at present circumscribed, should probably be sought among the somewhat shrubby species from the coast of Central Chile, e.g. E. berterianus DC. and E. litoralis (Phil.) Skottsberg. (cf. Skottsberg, 1950, pp. 158-164), and the Juan Fernandez Islands."

*-D. lancifolius (Hook.f.) Harling ssp. lancifolius - F, I; common in the Transition Zone and above. Included in Wiggins and Porter (1971) under D. tenuifolius var. glabriusculus (Stewart) Cronq., dispersed by wind via the pappus.

*-D. lancifolius ssp. glandulosus Harling - F, I; common in shrubby vegetation on cinders. Included in Wiggins and Porter (1971) under D. tenuifolius var. glandulosus (Harling) Cronq., probably dispersed by wind via the pappus, although birds have been seen occasionally on and/or appearing to feed on the flowers (personal observation). *-D. lancifolius ssp. glabriusculus Stewart (1911) I; common at higher elevations on Volcan Sierra Negra and Cerro Azul only, probably dispersed by wind via the pappus, although birds have been seen occasionally on and/or appearing to feed on the flowers (personal observation).

*-D. tenuifolius (Hook.f.) Harling ssp. tenuifolius - I, Pta, SaM, SS; common in the Transition and Scalesia Zones. Included in Wiggins and Porter (1971) as var. tenuifolius, dispersed by wind via the pappus.

*-D. tenuifolius (Hook.f) Harling spp. santacruzianus Harling - SaC; Scalesia Zone. Included in Wiggins and Porter (1971) under var. tenuifolius, dispersed by wind via the pappus.

*-Delilia. A genus of three species, the third being the tropical American D. biflora (L.) Kuntze, recently reported from the Galápagos as an introduced weed (van der Werff, 1977). Included in Wiggins and Porter (1971) as Elvira, but Stuessy (1975) has pointed out that the former is the older name; the Galápagos endemics are closely related to D. biflora which is the only other member of the genus.

*-D. inelegans (Hook.f.) Kuntze - SaM; known only from the type collection, made by Darwin in 1835. Included in Wiggins and Porter (1971) as Elvira inelegans (Hook.f.) Robins; dispersed by wind (achenes are housed within persistent involucral bracts which are dispersed as a unit).

*-D. repens (Hook.f.) Kuntze - F, I, SaC, SS; occurring in woody vegetation from sea level to $1400 \mathrm{~m}$. Included in Wiggins and Porter (1971) as Elvira repens (Hook.f.) Robins. Dispersed by wind (achenes are housed within persistent involucral bracts which are dispersed as a unit).

-D. biflora (L.) Kuntze (van der Werff 1977), introduced weed, tropical America distribution and origin. 
^-Eclipta alba (L.) Hassk. Pantropical distribution, originally from tropical America. Dispersal by birds (external in mud or internal; achenes 2-2.5 mm long).

*-Encelia hispida Anderss. - SaF, SaM, SC, SS; Arid Zone. According to Cronquist (in Wiggins and Porter, 1971), "closely related to E. canescens Lam., of the Peruvian coast, and the two may eventually prove to be conspecific." Dispersed by wind (achenes are 4-5 $\mathrm{mm}$ long, densely pubescent, with the upper trichomes surpassing the achene body by more than $1 \mathrm{~mm}$ ).

^-Enydra maritime (HBK.) DC. Andean (Pacific coast of tropical South America) distribution, dispersal by birds (external in mud or internal; achenes ca $2 \mathrm{~mm}$ long). -Erechitites hieracifolia var. cacaloides (Spreng.) Griesb. (van der Werff 1977), introduced weed, pantropical distribution, originally from tropical America. -Flaveria bidentis (L.) Kuntze, introduced weed, tropical America distribution. -Fleischmannia pratensis (Klatt) King \& Robins. (as Eupatorium pycnocephalum Less.; King \& Robinson 1975), introduced weed, tropical America distribution.. -Galinsoga urticaefolia (HBK.) Benth. (van der Werff 1977), introduced weed, pantropical distribution, originally from tropical America.

-Gnaphalium purpureum L. introduced weed, tropical American distribution.

-G. vira-vira Molina, introduced weed, Andean origin.

*-Jaegeria gracilis Hook.f. - F, I, Sac, SaM, SC, SS; common in the Miconia and FernSedge Zones; $2 n=36$, tetraploid (Torres, 1968). Most closely related to the tropical American J. crassa Torres (van der Werff, 1977), recognized as separate in Wiggins and Porter (1971); also closely related J. hira (Lag.) Less. Dispersed by birds (external in mud; achenes ca $1 \mathrm{~mm}$ long).

-Jungia hirsuta Cuatr. introduced weed, Andean origin.

$\wedge$-Koanophyllon solidaginoides (HBK.) King and Robins. (as Eupatorium solidaginoides HBK.; King and Robinson (1971), topical American origin (Mexico to Ecuador),

dispersed by wind (achenes 1.5-2.5 mm long, pappus abundant and longer than achenes). *-Lecocarpus. An endemic genus most closely related to Acanthospermum and Melampodium (Steussy, 1970; Eliasson, 1971).

*-L. lecocarpoides (Robins. \& Greenm.) Cronq. And Stuessy - Esp, Gar (Esp), SC; Arid Zone. Dispersed by birds (external, mechanical attachment; achenes; see Carlquist 1966; 41-42).

*-L. darwinii (Blake) Conq. \& Stuessy - Sc; Arid Zone; known only from the type collections, made by Stewart in 1906. Perhaps not distinct from L. lecocarpoides. Dispersed in same manner as L. lecocarpoides.

*-L. pinnatifidus Decne. - SaM; on cinders in the Arid Zone; $2 \mathrm{n}=22$ (Eliasson, 1970; as $L$. foliosus Decne.). Dispersed in same manner as L. lecocarpoides.

*-Macraea. A monotypic endemic genus, greatest affinities to Macraea are considered to be Wedelia, "particularly among the American species of this genus." (Harling, 1962, p. 98), which is a tropical and warm temperate genus of about 70 species. For centuries Macraea was cited as Lipochaeta, which belongs to the same tribe as Macraea, Heliantheae, but is restricted to the Hawaiian Islands. Harling (1962) was the first to do a critical study of Macraea and gave it its present name. Macraea has a diploid chromosome number of $2 \mathrm{n}=28$ (Eliasson, 1984). 
*-M. laricifolia Hook. f. - F, I, Pta, R, SaC, SaF, SaM, SC, SS; in open shrubby vegetation on cinders from near sea level to $1200 \mathrm{~m}$ or higher. Dispersed by birds (external, mechanical attachment; achenes; see Carlquist, 1966).

*-Pectis. "Both Galápagos Islands species are members of an unnamed South American section of Pectis" (Keil, 1977).

$-P$. linifolia $\mathrm{L}$. Introduced weed, Caribbean origin.

*-P. subsquarrosa (Hook. f.) Schultz Bip. - Bal, Bar, Eden, Esp, F, Gar (Esp), I, Pta, Pzn, $\mathrm{R}, \mathrm{S}, \mathrm{Sac}, \mathrm{SaF}, \mathrm{SaM}, \mathrm{SC}, \mathrm{SS}$; Arid Zone; $\mathrm{n}=36$, hexaploid (Kyhos in Wiggins and porter 1971; Keil, 1977). Dispersed by birds (external, mechanical attachment; achenes 2.5-3.5 $\mathrm{mm}$ long, minutely hispidulous, minutely barbed pappus 2-3 $\mathrm{mm}$ long).

*-P. tenuifolia (DC.) Schultz Bip. - f, I, G, SaC, SC; Arid Zone. Dispersed by birds (external, mechanical attachment; achenes 3-4 mm long, minutely hispidulous, minutely barbed pappus 3-5 mm long).

-Porophyllum ruderale var. macrocephalum (DC.) Cronq. Introduced weed, tropical American origin.

-Pseudelephantopus spicatus (Aubl.) C. F. Baker; introduced weed, pantropical distribution, originally from tropical America.

*-Scalesia. The fourth and largest endemic composite genus. It is a member of the tribe Heliantheae, subtribe Verbesininae, being closely related to Tithonia and Viguiera (Ono, $1967 \mathrm{a}, \mathrm{b})$ or to Helianthus and Viguiera (Elisson, 1974), with which it shares the basic chromosome numbers of $\mathrm{x}=17$ (all taxa of Scalesia so far counted are tetraploids $2 \mathrm{n}=68$ ). Helianthus has about 100 species in North and South America, Tithonia about 10 species in Mexico, Central America, and the West Indies, and Viguiera about 150 species in the warmer parts of the Americas. Scalesia appears to be most closely related to the South American representatives of Helianthus (subgenus Viguieropsis) and Viguiera (Eliasson, 1974), many of which have Andean distributions. A singe original introduction has given rise to this genus, the prime example of adaptive radiation in Galápagos Plants. The treatment of Scalesia follows that of Eliasson's (1974) monograph. Original introduction was most likely by birds (Carlquist 1966).

*-S. affinis Hook.f. ssp affinis - SaM (W. side); Arid Zone, dispersed by birds (external, mechanical attachment; achenes 2.5-4 mm long, pappus absent or rudimentary).

*-S. affinis ssp. brachyloba Harling - SaC (S. side); Arid and Transition Zones; $2 \mathrm{n}=68$ (Ono, 1967a; Eliasson, 1970; both as S. affinis); dispersed by birds as in ssp. affinis. *-S. affinis ssp. gummifera (hook.f.)Harling - $\mathrm{f}$, I; Arid Zone; $2 \mathrm{n}=68$ 9Eliasson, 1974); dispersed by birds (external, mechanical attachment; achenes $2.5-4 \mathrm{~mm}$ long, pappus rarely forming an awn to almost as long as the achene).

*-S. aspera Anderss. - Eden, SaC (n. side); Arid and Transition Zones; $2 \mathrm{n}=68$ (Eliasson, 1974); dispersed by birds (external, mechanical attachment; achenes $4-5 \mathrm{~mm}$ long, pappus rarely prolonged into 2 awns to ca $4 \mathrm{~mm}$ long).

*-S. atractyloides Arn. var. atractyloides - SS; Arid Zone; dispersed by birds (external, mechanical attachment; achenes 3-4 mm long, pappus sometimes forming 1-2 short awns).

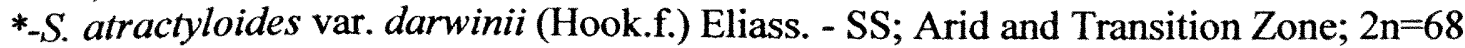
(as $S$. atractyloides Eliasson, 1974;60); endemic, dispersed by birds as in var. atractyloides. 
*-S. baurii Robins \& Greenm. ssp. baurii - Pzn; Scalesia Zone; 2n=68 (Ono, 1971); dispersed by birds (external, mechanical attachment; achenes $3.5-4 \mathrm{~mm}$ long, pappus absent or rudimentary and forming 1-2 small callosities).

*-S. baurii ssp. hopkinsii (Robins.) Eliass. - Pta, W; Arid and Transition Zones; $2 \mathrm{n}=68$ (Eliasson, 1970; as S. hopskinsii); dispersed by birds as in ssp. baurii.

*-S. cordata Stewart - I (S. half); cinder soils at both low (100-350 m) and high (1280$1600 \mathrm{~m}$ ) elevations; dispersed by birds (external, mechanical attachment; achenes $3.5 \mathrm{~mm}$ long, pappus generally of 2 laciniate-margined awns to $2 \mathrm{~mm}$ long).

*-S. crockeri Howell - Bal, S, SaC (N. side); Arid Zone; 2n=68 (Eliasson, 1970); dispersed by birds (external, mechanical attachment; achenes $4-5 \mathrm{~mm}$ long, pappus apparently absent).

*-S. divisa Anderss. - SC; Arid Zone; $2 \mathrm{n}=68$ (Eliasson, 1974); dispersed by birds (external, mechanical attachment; achenes $4-5 \mathrm{~mm}$ long, pappus rarely present as 1-2 pointed callosities to ca $0.5 \mathrm{~mm}$ long).

*-S. helleri Robins. ssp. helleri - SaC (S. side), SaF; Arid Zone; $2 \mathrm{n}=68$ (Eliasson, 1974); dispersed by birds (external, mechanical attachment; achenes 2-4 mm long, pappus absent or present as low callosities).

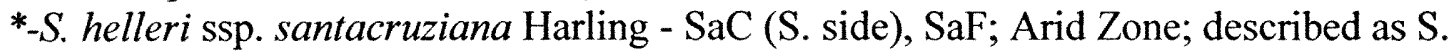
helleri; Eliasson 1974:89), dispersed by birds (external, mechanical attachment; achenes 2-4 mm long, pappus absent or present as low callosities).

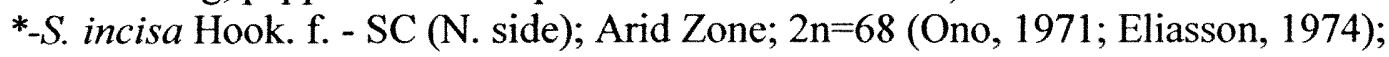
dispersed by birds (external, mechanical attachment; achenes $4-4.5 \mathrm{~mm}$ long, pappus apparently absent).

*-S. microcephala Robins var. microcephala - F, I; more common at higher elevations; $2 \mathrm{n}=68$ (Eliasson, 1970; Ono, 1971); dispersed by birds (external, mechanical attachment; achenes 3-4 mm long, pappus rarely present, of 1-2 awns to ca $1.5 \mathrm{~mm}$ long).

*-S. microcephala var. cordifolia Eliass. - I (N. side); 400-1600m, apparently in mesic woodlands; dispersed by birds as in var. microcephala.

*-S. pedunculata Hook.f. - SaC, SaM, SC, SS; Scalesia Zone; 2n=68 (Ono, 1967a, 1971; Eliasson, 1974); dispersed by birds (external, mechanical attachment; achenes 4-6 mm long, pappus rarely forming a short awn).

*-S. retroflexa Hemsl. - SaC (SE part); Arid Zone; dispersed by birds (external, mechanical attachment; achenes $4 \mathrm{~mm}$ long, pappus absent).

*-S. stewartii Riley - Bar, SS 9E. side); Arid Zone; 2n=68 (Ono, 1971); dispersed by birds (external, mechanical attachment; achenes 3-4 mm long, pappus apparently absent). *-S. villosa Stewart - Cal, Cha, Gar (SaM), O, SaM; on cinder soils in the Arid Zone; $2 n=68$ (Eliasson, 1974); dispersed by birds (external, mechanical attachment; achenes 3-4 mm long, pappus apparently absent).

-Sonchus oleraceus L. Introduced weed, pantropical distribution, originally from the Old World.

-Spilanthes acmella (L.) Murr. Introduced weed, pantropical distribution.

*-Spilanthes darwinii D. M. Porter - SaM, SC, SS; Scalesia Zone. Spilanthes is a tropical genus of about 60 species; $S$. darwinii is presumably related to one of the many tropical American species. It was listed by Cronquist (in Wiggins and Porter, 1971) as $S$. diffusa 
Hook.f., a later homonym of S. diffusa Poepp. \& Endl. Dispersed by birds (external, mechanical attachment; achenes 1.4-1.5 mm long, pappus absent or of 1 small awn). -Synedrella nodiflora (L.) Gaertn. Introduced weed, pantropical distribution, originally from tropical America.

-Tridax procumbens L. (van der Werff 1977) Introduced weed, pantropical distribution, originally from Central America. 

and their conservation status:

Where:

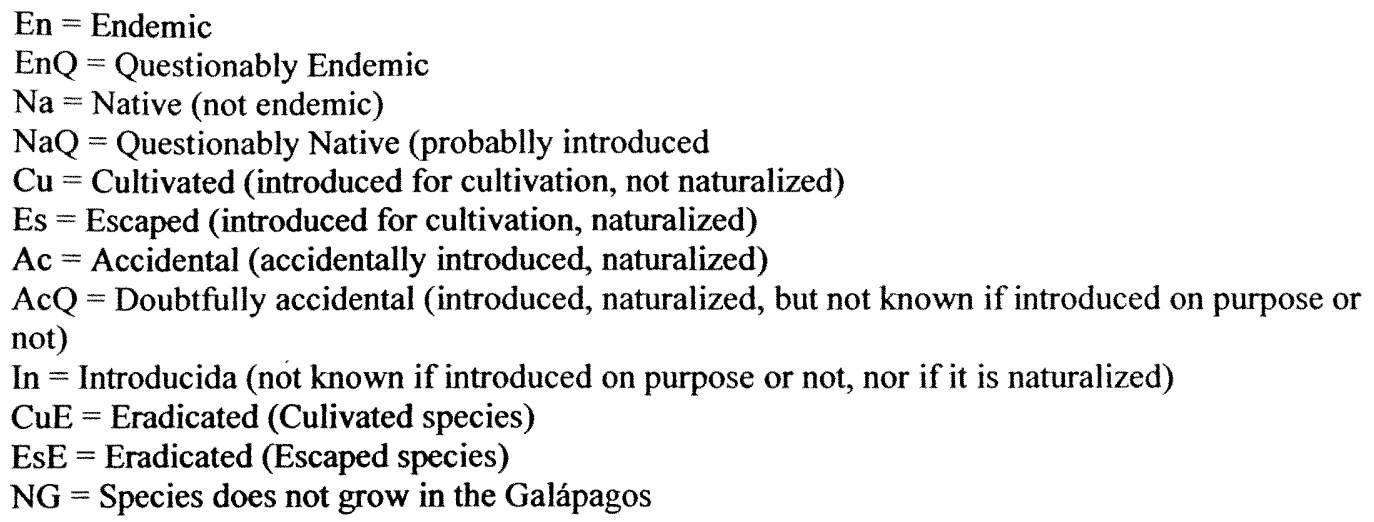

Genus

Acanthospermum

Acmella

Acmella

Acmella

Adenostemma

Ageratum

Ambrosia

Anthemis

Baccharis

Baccharis

Bidens

Bidens

Bidens

Blainvillea

Brickellia

Centratherum

Chrysanthellum

Chrysanthellum

Chrysanthemum

Conyza

Conyza

Conyza

Cosmos

Dahlia

Darwiniothamnus

Darwiniothamnus

Darwiniothamnus

Darwiniothamnus

Darwiniothamnus

Darwiniothamnus
Species

microcarpum

ciliata

darwinii

sodiroi

platyphyllum

conyzoides

peruviana

nobilis

gnidiifolia

steetzii

cynapiifolia

pilosa

riparia

dichotoma

diffusa

punctatum

fagerlindii

pusillum

peggy

bonariensis

bonariensis

canadensis

bipinnatus

pinnata

alternifolius

lancifolius

lancifolius

lancifolius

lancifolius

tenuifolius
Origen

$\mathrm{NaQ}$

AcQ

En

Ac

Ac

$\mathrm{NaQ}$

Ac

$\mathrm{Cu}$

$\mathrm{Na}$

En

Ac

$\mathrm{NaQ}$

$\mathrm{Na}$

$\mathrm{Na}$

$\mathrm{NaQ}$

Es

En

En

$\mathrm{Cu}$

Ac

Ac

Ac

$\mathrm{Cu}$

$\mathrm{Cu}$

En

En

En

En

En

En 


\begin{tabular}{|c|c|c|}
\hline Darwiniothamnus & tenuifolius & En \\
\hline Delilia & biflora & $\mathrm{NaQ}$ \\
\hline Delilia & inelegans & En \\
\hline Delilia & repens & En \\
\hline Eclipta & prostrata & $\mathbf{N a}$ \\
\hline Encelia & hispida & En \\
\hline Enydra & sessilifolia & $\mathbf{N a}$ \\
\hline Erechtites & hieraciifolius & Ac \\
\hline Flaveria & bidentis & Ac \\
\hline Fleischmannia & pratensis & Ac \\
\hline Galinsoga & quadriradiata & Ac \\
\hline Gamochaeta & purpurea & $\mathrm{NaQ}$ \\
\hline Gazania & splendens & $\mathrm{Cu}$ \\
\hline Gnaphalium & viravira & $\mathbf{N a Q}$ \\
\hline Helianthus & annuus & $\mathbf{C u}$ \\
\hline Jaegeria & gracilis & En \\
\hline Jungia & hirsute & Ac \\
\hline Koanophyllon & solidaginoides & $\mathbf{N a}$ \\
\hline Lactuca & sativa & $\mathrm{Cu}$ \\
\hline Lecocarpus & darwinii & En \\
\hline Lecocarpus & lecocarpoides & En \\
\hline Lecocarpus & pinnatifidus & En \\
\hline Macraea & laricifolia & En \\
\hline Matricaria & recutita & $\mathbf{C u}$ \\
\hline Pectis & linifolia & $\mathrm{NaQ}$ \\
\hline Pectis & subsquarrosa & En \\
\hline Pectis & tenuifolia & $\mathbf{E n}$ \\
\hline Porophyllum & ruderale & Ac \\
\hline Pseudelephantopus & spicatus & Ac \\
\hline Pseudelephantopus & spiralis & Ac \\
\hline Pseudogynoxys & scabra & $\mathbf{C u}$ \\
\hline Scalesia & affinis & En \\
\hline Scalesia & aspera & En \\
\hline Scalesia & atractyloides & En \\
\hline Scalesia & \multicolumn{2}{|c|}{ atractyloides/stewartii hybrids } \\
\hline Scalesia & bauri & En \\
\hline Scalesia & cordata & En \\
\hline Scalesia & crockery & En \\
\hline Scalesia & divisa & En \\
\hline Scalesia & divisa/incisa & En \\
\hline Scalesia & gordilloi & En \\
\hline Scalesia & helleri & En \\
\hline Scalesia & incisa & En \\
\hline Scalesia & microcephala & En \\
\hline Scalesia & pedunculata & En \\
\hline Scalesia & retroflexa & En \\
\hline Scalesia & stewartii & $\mathbf{E n}$ \\
\hline Scalesia & villosa & $\mathbf{E N}$ \\
\hline Smallanthus & sonchifolius & $\mathrm{Cu}$ \\
\hline
\end{tabular}


Soliv

Sonchus

Synedrella

Tagetes

Tanacetum

Taraxacum

Tridax

Zinnia anthemifolia

oleraceus

nodiflora

erecta

cinerariifolium

officinale

procumbens

peruviana
Na

Ac

Ac

Cu

$\mathrm{Cu}$

AcQ

Ac

$\mathrm{NaQ}$ 
APPENDIX 2: A list of the current status of each population of Darwiniothamnus collected from at various sites throughout the archipelago. The order of the islands, and specific areas within each island listed trace the route I followed on my four separate collecting trips within the archipelago.Included are notes on different growth forms, the greatest biological dangers at each site and recommendations for future conservation work, where needed.

Island: Santa Cruz

Location: Los Gemellos

Species present: $D$. tenuifolius ssp. santacruzianus

Additional remarks: The population near los Gemellos is restricted to one small and very crowded population of exactly 7 plants. All plants are large and seemingly healthy, but unfortunately show the initial sign of Icerya purchasi (cottony cushion insect) infestation. A couple of the insects appeared to be ovigerous, thus I recommend that the population be monitered carefully over the next few years to ensure its protection. The leaves of this ssp.ecies are at least 2-4 times longer than other members from the same species and about half to a quarter as wide. In addition, the leaves are remotely hairy on both the ad and abaxial sides with several sharp teeth lining the margins.

Island: Santa Cruz

Location: area surrounding Cerro Crocker towards "los Picachos"

Species Present: D. tenuifolius ssp. santacruzianus

Additional remarks: This population was much more healthy than the one at los

Gemellos, comprising of approx. 30 rather small plants; all of which share the similar leaf descriptions as those mentioned above. No presence of $I$. purchasi noticed and the only force apparently threatening the existence of this population is the large amount of Pteridium aquilinum (bracken fern) growing around, over and shading several members of the population; competition for light must be a factor. First sign of interesting, rhizomatous-like growth.

Island: Pinzón

Location: first stop on eastern side, second stop of western side of the island Species Present: none

Additional remarks: D. tenuifolius previously inhabited this island, but after extensive searching, no extant populations were found...extinction probably due to foraging by goats.

Island: Isabela

Location: Cartago Bay (Bahia Cartago)

Species Present: D. tenuifolius

Additional remarks: Very large population found spanning ca $5 \mathrm{~km}^{2}$ or more. Leaves surfaces (ad and abaxial) are completely glabrous in the entire population. I. purchasi present in abundance, several of which are ovigerous. 
Island: Isabela

Location: trail up to Volcan Alcedo, started at Pta. Alfaro (no plants found at or around rim of the crater)

Species Present: D. tenuifolius

Additional remarks: several populations collected here. Several of the plants had leaves which were remotely denticulate, pubescent to densely pubescent, with hairs that were increasingly glandular with elevation.

Island: Isabela

Location: trail down from Volcan Alcedo (old trail facing NNE, which comes out near Pta. Garcia)

Species Present: D. tenuifolius

Additional remarks: several dead plants found along old river bed...only ca 10 plants found alive (presumably to $I$. purchasi, although none was found), whose leaves were much more linear than those found on the other trail leading up to the volcano. In addition, both surfaces of all leaves studied were completely glabrous and somewhat bullate; possibly a different variety (as are reproductively isolated) or just variation within the species.

Island:Isabela

Location:Volcan Wolff, (entered at "Piedras Blancas," half way between Pta. Albermarle and Pta. Flores).

Species Present: D. lancifolius ssp. glandulosus

Additional remarks: First sign of this species, fairly healthy populations; no sign of $I$. purchasi present. All leaves studied from this area were fairly coriaceous (sometimes with reddish margins and tips) with mucronate apices, and had glandular hairs covering both surfaces. A few of the new leaves from this population were oddly circinate, and some even had dead flowers and/or seeds inside.

Island: Isabela

Location: lower elevations of Volcan Ecuador (entered just south of Cabo Berkely) Species Present: D. lancifolius ssp. glandulosus

Additional remarks: Again, fairly healthy plants, but very spread out and solitary. No sign of I. purchasi. Leaves showed all the same characteristics as from Volcan Wolff, except the glandular hairs were much finer on all specimens examined from this location.

Island: Fernandina

Location: Cabo Douglas

Species Present: D. lancifolius ssp. glandulosus

Additional remarks: Very healthy and large population found here - same remarks as for V. Ecuador and V. Wolff; this time, however, glandular hairs are much shorter \& stubbier. 
Island: Fernandina

Location: Lava stand in back of Roca Tarzan and base of Volcan Fernandina

Species Present: D. lancifolius ssp. glandulosus

Additional remarks: Healthiest population found in entire archipelago, the species forms huge stands and is definitely the most prolific plant on the island. No sign of I. purchasi. Same leaf description as found on Cabo Douglas, except there was greater leaf length and width variation found throughout the island. In addition, longer hair was found on the undersides of leaves and shorter \& more stubby glands were found on top of all specimens studied from a variety of altitudinal gradients.

Island: Isabela

Location: Volcan Darwin (entered at Tagus Cove)

Species Present: D. lancifolius ssp. glandulosus and D. tenuifolius

Additional remarks: Several somewhat clustered populations were found ranging from the lava stand at the end of the tourist trail all the way up to the rim of the volcano.

Leaves of both species were extremely densely covered with glandular hairs, which were more pannose than pilose. A possible population of hybrids was also found which was neither clearly $D$. tenuifolius nor $D$. lancifolius at first glance. Additional morphological studies should help clarify the taxonomic position of species from this area. Again, luckily no presence of $I$. purchasi was found.

Island: Isabela

Location: Pta. Tortuga Negra

Species Present: D. lancifolius ssp. glandulosus and D. tenuifolius

Additional remarks: Additional smaller and more scattered populations found here, again no presence of I. purchasi was found. First time D. lancifolius was found growing directly on the sand only a couple of meters from the ocean. Same leaf descriptions can be used here as for V. Darwin, except the glands and glandular hairs seemed to be smaller and finer on all specimens examined.

Island: Isabela

Location: Bahia Urvina

Species Present: D. lanifolius ssp. glandulosus/glabriusculus?

Additional remarks: Interesting population here - hair found on both sides of the leaves but only very rarely possessing glands. Population found growing only on the lava and not at all on the flat lands/savannah, and several plants found dead and/or dieing. $I$. purchasi unfortunately found on all plants (both live and dead) in abundance at this location. (Note: this site is a favorite among the tourist stops - thus the spread of $I$. purchasi to this location could be a direct correlation; and/or as a result of transportation by wind from Volcan Alcedo.)

Island: Isabela

Location: Bahia Elizabeth

Species Present: none

Additional remarks: not a single plant found from any species after extensive searching. 
Island: Isabela

Location: Pta. Moreno

Species Present: D. lancifolius ssp. glandulosus

Additional remarks: Fairly large and scattered population found here. Oddly, no sign of

I. purchasi. Plants seemingly healthy and match description of Pta. Tortuga Negra.

\section{Island: Isabela}

Location: Volcan Sierra Negra - Eastern edge of "El Alemania" in an area called "El

Velasco" (savannah region, S-SSE slope of volcano)

Species Present: D. lancifolius ssp. glabriusculus, D. tenuifolius, D. alternifolius

Additional remarks:

-D. l. glab: very healthy populations, leaves of this ssp. are more quadrate than lanceolate (as in D. l. glandulosus) and extremely hairy underneath, seemingly manicate \& somewhat glandular. Leaf surfaces are more or less glabrous and bullate. No presence of I. purchasi readily detected.

-D. tenuifolius: populations are rather small and restricted to only a few areas (D. l. glab. is definitely more abundant). Leaves of $D$. ten.at this location are more or less glabrous and bullate.

$-D$. alternifolius: only a very small population found here by sheer luck. Henning Adsersen (personal communication, 2002) has stated that the population(s) of $D$. alternifolius in this area suffered greatly from the 1985 fire in the area. The fire devastated most of the area $D$. alternifolius inhabited on Sierra Negra and most of the vegetation development after the fire would be unlikely to favor $D$. alt. The leaves of this third species have tiny gland-like dots on the adaxial surface and are rather pillose on the abaxial side.

Island: Isabela

Location: Volcan Sierra Negra - rim of crater, past the sulpher plumes

Species Present: D. lancifolius ssp. glabriusculus and D. tenuifolius only

Additional remarks: same description for both as was found in El Velasco. Another possible population of hybrids perhaps detected here as well, which are intermediate in leaf shape, hair type, and plant size. No presence of $I$. purchasi readily detected.

Island: Isabela

Location: Volcan Sierra Negra - trail to base VSN, west of El Velasco.

Species Present: D. lancifolius ssp. glabriusculus only

Additional remarks: same description as was found in El Velasco. No presence of $I$. purchasi readily detected.

Island: Isabela

Location: Volcan Cerro Azul

Species Present: $D$. lancifolius ssp. glabriusculus and D. alternifolius only 
Additional remarks: Individual plants of D. $l$. glab. were scattered from Media Luna up to the rim and within the crater, rarely in clusters of 2 or 3 . Same description as for those in El Velasco, with the plants very healthy and apparently unaffected by the feral pig and cattle population. Several plant of $D$. alt . were also found, clustered together in definite populations from approx. $1 / 2 \mathrm{~km}$ south of Media Luna to about half-way up the volcano. This seems to be the last remaining location where this species survives in relative abundance and although there was no presence of $I$. purchasi readily detected, I believe that these plants may be fed upon by any number of the feral animals present at this location.

\section{Island: Santiago}

Location: landed near Caleta Bucanero, Puerto Egas and at an unnamed area on the southeastern coast of the island.

Species Present: D. tenuifolius only at all three locations

Additional remarks: The plants of this species found at all three locations were scattered and relatively few. A large population of feral goats continue to live on this island which have been seen feeding on the plants on numerous occasions. This may explain why the largest and healthiest plants were found either within sink holes, behind protective fencing, and/or in huge lava stands, not often traversed by the animals. Some presence of I. purchasi was found, especially along the southern coast on those plants growing in the lava stands. An interesting morphological adaptation was found among all plants studied from this island in that they are pillose both on the ad and abaxial surfaces of the leaves. This is the first time a member of this species has been seen with such a degree of hairiness and across such a wide area. Stewart (1911) even considered giving plants from this area their own ssp.ecific epithet "tomentosus," and although I agree with his findings, I will wait for a careful morphological analysis to be completed before I formally say so.

\section{Island: Marchena}

Location: landed at Playa Negra and again between Pta. Mejia and Pta. Montalvo Species Present: none

Additional remarks: after extensive searching by six of my colleagues from the CDRS, I am certain that no members of this genus reside on this island, from which it has never been recorded.

Island: Pinta

Location: arrived in between Cabo Ibbetson and Cabo Chalimers; and left the island on the other side in between Cabo Ibbetson and Rocas Nerus.

Species Present: D. tenuifolius

Additional remarks: Upon arrival it appeared that all members of this species had died out due to an extreme infestation of $I$. purchasi, which was perhaps the worst infestation seen so far and definitely comparable to that of Volcan Alcedo. However, upon summiting the solitary volcano on the island and continuing down the other side we found great stands of somewhat rather small plants of D. ten, all healthy and apparently not yet affected by $I$. purchasi. The leaves of the plants on this island share the same attributes as those on Santiago, and are even more odd in that they are extremely 
tomentose on both sides of the leaf blade. I definitely feel that the representatives of this species on Pinta deserve at least a new ssp.ecific epithet, but again will wait to do so until I have completed a detailed morphological study of all species across the entire archipelago.

Island: Floreana

Location: I did not visit this island, but was sent material from it Species Present: $D$. tenuifolius

Additional remarks (A. Tye, personal communication): Scattered bushes in the upper arid zone and transition zones of the western side of the island and western half of the central plateau, in amongst scrub and open Scalesia pedunculata woodland. The scrub habitat is dominated in places by the introduced Lantana camara but it is not known if the latter is adversely affecting the Darwiniothamnus. 
APPENDIX 3: Notes on the soil analyses run for each sample collected within the Galápagos Islands. General information on the trends from location to location are also included and more specific information regarding these trends can be found in the text of Chapter 3.

SOIL $\mathrm{pH}$. Soil $\mathrm{pH}$ levels have a direct influence over the availability of both macro and micro nutrients and their uptake by plants. The results of these analyses indicates that the soils have $\mathrm{pH}$ 's ranging from very acidic to strongly alkaline (4.8 to 8.6); and the samples average was 7.15 collectively. The most acidic soils were found on Cerro Azul and Fernandina. The most alkaline soils were found on Volcán Ecuador and Volcán Wolf.

SOIL SALINITY. ECe levels were found to be within accepted agriculture limits for growing plants in most areas. For non-stressed plants, in general, a soil ECe of $<1.5$ $\mathrm{mmho} / \mathrm{cm}$ is considered ideal. Most samples fell within this range except sample 13 from Fernandina in population 6 , which was 3.4 and samples 1 and 2 which were extraordinarily high at 6.1 and 5.9. There is, as of yet, no explanation for the large variance.

SOLUBLE CALCIUM. The amount of soluble calcium within soil is very important in water infiltration for growing plants. Since there are vast differences in the climatic conditions and rainfall on each island, this subject has little bearing on the overall results except to note that Soluble Calcium levels of $8.0 \mathrm{meq} / \mathrm{liter}$ are considered adequate for proper water infiltration. All but five of the 29 samples were well below this threshold.

NITROGEN (N). Nitrogen is a very important component in chlorophyll development. The broad range of available nitrogen as determined by dry soil and by Saturation Extract was all over the board. The Nitrate-Nitrogen ranged from a low of $3 \mathrm{ppm}$ at site \#23 on Marchena and only 2 ppm at site \# 27 on Santíago to a high of $497 \mathrm{ppm}$ at site 3 on Fernandina. The low level of Nitratre-Nitrogen in the soil on the island of Marchena may be a reason why no members of Darwiniothamnus have ever been known to inhabit this island, but this is only a rudimentary hypothesis and one which ought to be studied further.

PHOSPHOROUS (p). The phosphorous levels for all samples across the archipelago were all in the levels necessary for typical plant development and growth.

POTASSIUM (K). Soil levels of potassium were found to be, in large part, high . A base soil level of $125 \mathrm{ppm}$ is considered to be adequate for most shrubs and vines. Potassium can become tightly bound upon clay particles and not be easily soluble however, no clay was observed in any of the soil samples. Potassium levels, expressed as ppm ranged from a low of 48 at site 27 on Santíago to a high of $2340 \mathrm{ppm}$ at site 9 on Volcán Alcedo. The numerical average for $\mathrm{K}$ is $620 \mathrm{ppm}$, suggesting our results are very high indeed. 
ZINC (ZN) AND BORON (B). The levels found of Zinc, and when possible Boron, are generally adequate for sustaining plant vigor and health. Since Zinc deficiencies are known to impact germination processes across several plant species, including some members of the Asteraceae, it would be interesting to see if the low levels found in some samples affected propagation. Future germination studies are therefore suggested with altering the levels of several different limiting nutrients, including Zinc and Boron.

CALCIUM/MAGNESIUM (CaMg). To provide proper nutrient uptake to plants, it is also important that soils contain higher percentages of calcium than magnesium. Soils that have less than two times the amount of calcium to magnesium will develop nutrient deficiencies. These deficiencies are due to the soils imbalance of calcium to magnesium which causes needed nutrients to be held tightly in the soil. The percentage of calcium to magnesium were found to be to a great degree below the minimum level considered desirable of 2.0. Samples number one and two were again out side the range of normal expectations, and should definitely be considered outliers. The Sodium Absorption Ratio $(\mathrm{Ca} / \mathrm{Mg})$ was 4.48 and the $\mathrm{pH}$ was 8.5 .

TRACE MINERALS. Only samples $17,18,25$, and 26 had statistically higher amounts of any of the trace elements. Iron (Fe) was high in all four. Sites 17 and 18 were taken from Volcan Sierra Negra, and samples 25 and 26 were taken from the island of Pinta. The high Iron content would lead one to believe that these were younger soils created by more recent Volcánoes, which could be the case for Volcan Sierra Negra, but not necessarily for the island of Pinta.

BIOMASS/ORGANIC MATERIAL AVAILABLE. It is readily known that an incredible diversity of organisms makes up the soil food web. These organisms can range in size from tinstone celled bacteria, algae, fungi, and protozoa; to more complex nematodes and micro-arthropods; to earthworms, insects, small vertebrates, and plants all readily seen by the human eye. As these organisms eat, grow, and move through the soil, they make it possible to have clean water, clean air, healthy plants, and moderated water flow. This typically normal, yet complex process however, probably only occurred at half of the sites where we collected soil. Several of the populations where I collected both plants and soil were located on vast stands of lava, where top soil (and the associated biomass and organic material) was either scant or absent altogether. In addition, many of the lava flows on Fernandina, Isabela and Santíago are so recent that vegetation has not yet colonized them and soil is practically nonexistent within their limits (Wiggens and Porter, 1971). This could be a reason for why Darwiniothamnus was found growing in great stands in some thick lava areas and was absent for miles in others; however it is more than likely that the reason has a lot to do with age, chance colonization and nearest source populations. The youngest flows with Darwiniothamnus present on seem to be more than 200 years old (e.g. SW Santiago) (A. Tye, personal communication). 
Appendix 3 cont.: Results of Soil Analyses for all 29 sample sites.

\begin{tabular}{|c|c|c|c|c|}
\hline Code & soil sample 1 & soil sample 2 & soil sample 3 & soil sample 4 \\
\hline \multicolumn{5}{|l|}{ SATURATION EXTRACT } \\
\hline Saturation percentage & 150 & 155 & 189 & 138 \\
\hline $\mathrm{pH}$ & 7.6 & 7.6 & 5.6 & 6.9 \\
\hline Ece (electrical conductivity) & 6.1 & 5.9 & 2.0 & 2.6 \\
\hline Ca meq (calcium) & 11.08 & 10.38 & 7.69 & 15.82 \\
\hline Mg meq (Magnesium) & 17.93 & 16.61 & 2.88 & 6.33 \\
\hline $\mathrm{Ca}+\mathrm{Mg}$ meq & 29.01 & 26.99 & 10.57 & 22.15 \\
\hline Na meq (sodium) & 32.19 & 27.84 & 7.83 & 4.35 \\
\hline K meq (Potassium) & 6.14 & 7.39 & 2.81 & 2.15 \\
\hline CARB meq (carbonate + bicarbonate) & 27.8 & 21.0 & 3.4 & 12.0 \\
\hline Cl meq (Chloride) & 45.6 & 61.1 & 8.4 & 8.6 \\
\hline $\mathrm{Na}$ ad (Sodium adsorption ratio) & 8.45 & 7.58 & 3.41 & 1.31 \\
\hline $\mathrm{Na}$ ex (exchangeable sodium percentage) & 10.1 & 9.0 & 3.7 & 0.7 \\
\hline Nitrate-nitrogen, satuartion extract, ppm & 31 & 30 & 62 & 50 \\
\hline Bo ppm (Boron) & & & 1 & 0.89 \\
\hline \multicolumn{5}{|l|}{ NUTRIENTS- DRY SOIL ESTIMATE } \\
\hline Nitrate-nitrogen, dry soil estimate, ppm & 47 & 47 & 117 & 69 \\
\hline P ppm (Phosphorus) & 39 & 42 & 27 & 6 \\
\hline K ppm (Potassium) & 1890 & 2020 & 990 & 700 \\
\hline \multicolumn{5}{|l|}{ TRACE METALS } \\
\hline Znppm & 64.0 & 67.0 & 41.0 & 9.6 \\
\hline Mnppm & 42.0 & 49.0 & 72.0 & 49.0 \\
\hline Feppm & 12.0 & 15.0 & 29.0 & 14.0 \\
\hline Cuppm & 3.0 & 3.8 & 3.0 & 2.0 \\
\hline \multicolumn{5}{|l|}{ EXCHANGABLE CATIONS: } \\
\hline \multicolumn{5}{|l|}{ ppm = $1 \mathrm{~N}$ Ammonium Acetate extraction } \\
\hline \multicolumn{5}{|l|}{ meq/100 $\mathrm{g}=$ Atomic absporption / } \\
\hline \multicolumn{5}{|l|}{ Flame Emission detection } \\
\hline K ppm (Potassium) & 1890 & 2020 & 990 & 700 \\
\hline K ppm (percentage only) & 14.4 & 13.6 & 10.2 & 3.9 \\
\hline $\mathrm{K}$ meq (Potassium) & 4.83 & 5.17 & 2.53 & 1.79 \\
\hline $\mathrm{K}$ meq (percentage only) & 6.8 & 6.4 & 5.2 & 1.9 \\
\hline Ca ppm (Calcium) & 5500 & 6170 & 7400 & 14650 \\
\hline Ca ppm (percentage only) & 42.0 & 41.4 & 76.2 & 81.4 \\
\hline Ca meq (Calcium) & 27.45 & 30.79 & 36.93 & 73.10 \\
\hline Ca meq (percentage only) & 38.4 & 37.8 & 75.7 & 77.7 \\
\hline Mg ppm (Magnesium) & 3700 & 4200 & 920 & 1990 \\
\hline Mg ppm (percentage only) & 28.3 & 28.2 & 9.5 & 11.1 \\
\hline Mg meq (Magnesium) & 30.43 & 34.54 & 7.57 & 16.37 \\
\hline Mg meq (percentage only) & 42.6 & 42.4 & 15.5 & 17.4 \\
\hline Na ppm (Sodium) & 2000 & 2500 & 400 & 650 \\
\hline Na ppm (percentage only) & 15.3 & 16.8 & 4.1 & 3.6 \\
\hline Na meq (Sodium) & 8.70 & 10.87 & 1.74 & 2.83 \\
\hline Na meq (percentage only) & 12.2 & 13.4 & 3.6 & 3.0 \\
\hline $\begin{array}{l}\mathrm{NH} 4-\mathrm{N} \text { (amonium-nitrogen)- as nitrogen, } \\
\mathrm{ppm}\end{array}$ & 2675 & 2595 & 2250 & 1225 \\
\hline Free Lime (Calcium Carbonate) & 0 & of & 0 & 0 \\
\hline$\%$ organic matter (wt. loss by combustion) & 57.1 & 66.7 & 88.0 & 76.4 \\
\hline \multicolumn{5}{|l|}{ texture } \\
\hline Color & & & $\begin{array}{l}\text { dk., charcoal } \\
\text { black }\end{array}$ & dk., brown/black \\
\hline Growers Testing Service sample number: & \#2181 & $\# 2182$ & \#2183 & \#2184 \\
\hline
\end{tabular}

ppm (or $\mathrm{mg} / \mathrm{l}$ ) $=$ equivalent weight $X$ meq $/ \mathrm{l} \mathrm{meq} / \mathrm{l}=\mathrm{ppm}($ or $\mathrm{mg} / \mathrm{l}) / \mathrm{eq} . \mathrm{wt}$. 


\section{Appendix 3 cont: Results of Soil Analyses for all 29 sample sites}

\begin{tabular}{|c|c|c|c|c|c|c|}
\hline ioil sample 5 & soil sample 6 & soil sample 7 & soil sample 8 & soil sample 9 & soil sampl 10 & soil sampl 11 \\
\hline & & & & & & \\
\hline 73 & 50 & 40 & 50 & 94 & 34 & 29 \\
\hline 7.4 & 7.3 & 8.6 & 8.2 & 7.4 & 8.2 & 6.6 \\
\hline 2.0 & 0.3 & 1.1 & 3.1 & 2.5 & 1.3 & 2.5 \\
\hline 6.39 & 1.60 & 4.83 & 14.52 & 13.22 & 5.34 & 11.83 \\
\hline 2.63 & 0.68 & 2.55 & 7.16 & 3.78 & 2.06 & 7.57 \\
\hline 9.02 & 2.28 & 7.38 & 21.68 & 17.00 & 7.40 & 19.40 \\
\hline 6.53 & 0.61 & 3.39 & 10.00 & 4.78 & 4.31 & 7.40 \\
\hline 4.19 & 0.20 & 0.15 & 1.92 & 4.54 & 1.13 & 0.56 \\
\hline 4.9 & 0.9 & 3.2 & 8.7 & 2.4 & 4.3 & 1.2 \\
\hline 9.8 & 0.8 & 5.9 & 17.9 & 3.5 & 4.4 & 19.8 \\
\hline 3.08 & 0.57 & 1.77 & 3.04 & 1.64 & 2.24 & 2.38 \\
\hline 3.2 & 0.1 & 1.4 & 3.1 & 1.2 & 2.0 & 2.2 \\
\hline 39 & 18 & 4 & 71 & 156 & & 26 \\
\hline 0.82 & 0.33 & 0.27 & 0.48 & 0.45 & 1.41 & 0.3 \\
\hline & & & & & & \\
\hline & & & & & & \\
\hline 28 & 9 & 2 & 36 & 147 & & 3 \\
\hline 18 & 29 & 27 & 100 & 29 & 16 & 68 \\
\hline 2190 & 1990 & 148 & 1000 & 2340 & 1010 & 118 \\
\hline & & & & & & \\
\hline 6.4 & 1.6 & 0.9 & 1.4 & 10.8 & 2.4 & 1.8 \\
\hline 4.0 & 2.8 & 0.8 & 3.8 & 5.4 & 3.1 & 4.8 \\
\hline 37.0 & 56.0 & 43.0 & 35.6 & 36.0 & 27.8 & 86.0 \\
\hline 0.8 & 1.2 & 1.2 & 1.2 & 2.0 & 2.0 & 1.8 \\
\hline & & & & & & \\
\hline & & & & & & \\
\hline & & & & & & \\
\hline & & & & & & \\
\hline & & & & & & \\
\hline 2190 & 1990 & 148 & 1000 & 2340 & 1010 & 118 \\
\hline 34.9 & 19.9 & 5.4 & 18.6 & 27.2 & 26.4 & 6.2 \\
\hline 5.60 & 5.09 & 0.38 & 2.56 & 5.98 & 2.58 & 0.30 \\
\hline 20.8 & 10.5 & 2.7 & 10.0 & 15.5 & 15.1 & 3.1 \\
\hline 3220 & 6720 & 2040 & 3380 & 5340 & 2140 & 1270 \\
\hline 51.4 & 67.1 & 74.0 & 62.8 & 62.1 & 55.9 & 66.2 \\
\hline 16.07 & 33.53 & 10.18 & 16.87 & 26.65 & 10.68 & 6.34 \\
\hline 59.8 & 69.2 & 73.1 & 66.0 & 69.2 & 62.3 & 64.5 \\
\hline 380 & 1070 & 230 & 460 & 490 & 240 & 230 \\
\hline 6.1 & 10.7 & 8.3 & 8.6 & 5.7 & 6.3 & 12.0 \\
\hline 3.13 & 8.80 & 1.89 & 3.78 & 4.03 & 1.97 & 1.89 \\
\hline 11.6 & 18.2 & 13.6 & 14.8 & 10.5 & 11.5 & 19.2 \\
\hline 480 & 240 & 340 & 540 & 430 & 440 & 300 \\
\hline 7.7 & 2.4 & 12.3 & 10.0 & 5.0 & 11.5 & 15.6 \\
\hline 2.09 & 1.04 & 1.48 & 2.35 & 1.87 & 1.91 & 1.30 \\
\hline 7.8 & 2.1 & 10.6 & 9.2 & 4.9 & 11.1 & 13.2 \\
\hline & & & & & & \\
\hline 1165 & 510 & 390 & 945 & 1090 & 430 & 375 \\
\hline 0 & \multicolumn{2}{|c|}{$\frac{510}{\text { omed }}$} & 0 & o & 0 & 0 \\
\hline \multirow[t]{2}{*}{13.6} & \multirow{2}{*}{\multicolumn{2}{|c|}{${ }^{10.9}$}} & 9.4 & 19.2 & 5.3 & \multirow{2}{*}{ fine } \\
\hline & & & fine & coarse & very fine & \\
\hline it brown & it brown & med gray & med gray & med brown & brown gray & med dk. gray \\
\hline & & \#2187 & \#2188 & 42180 & turas & \\
\hline 2185 & \#2186 & \#2187 & \#2188 & $\# 2189$ & \#2190 & \#2191 \\
\hline
\end{tabular}




\section{Appendix 3 cont: Results of Soil Analyses for all 29 sample sites}

\begin{tabular}{|c|c|c|c|c|c|}
\hline soil sample 12 & Soil sample 13 & soil sample 14 & soil sample 15 & soil sample 16 & soil sample 17 \\
\hline & & & & & \\
\hline 33 & 50 & 45 & 80 & 39 & 100 \\
\hline 6.9 & 7.0 & 6.6 & 8.1 & 8.5 & 4.8 \\
\hline 0.8 & 3.4 & 0.3 & 0.9 & 0.3 & 0.5 \\
\hline 2.85 & 27.69 & 1.74 & 3.18 & 0.40 & 1.78 \\
\hline 2.63 & 6.33 & 1.05 & 0.82 & 0.28 & 0.94 \\
\hline 5.48 & 34.02 & 2.79 & 4.00 & 0.68 & 2.72 \\
\hline 2.18 & 1.74 & 0.53 & 3.92 & 2.61 & 1.70 \\
\hline 0.56 & 2.33 & 0.08 & 1.15 & 0.15 & 0.63 \\
\hline 0.3 & 1.9 & 0.3 & 4.1 & 0.7 & 0.2 \\
\hline 0.3 & 0.6 & 0.6 & 2.5 & 2.2 & 0.2 \\
\hline 1.32 & 0.42 & 0.45 & 2.77 & 4.48 & 1.46 \\
\hline 0.7 & 0.1 & 0.1 & 2.8 & 5.1 & 0.9 \\
\hline 81 & 497 & 31 & 47 & 2 & 3 \\
\hline 0.27 & 0.3 & 0.3 & 0.48 & 0.24 & 0.27 \\
\hline & & & & & \\
\hline & & & & & \\
\hline 27 & 249 & 14 & 38 & 1 & 3 \\
\hline 15 & 32 & 7 & 15 & 2 & 32 \\
\hline 108 & 510 & 128 & 2110 & 204 & 214 \\
\hline & & & & & \\
\hline 1.2 & 2.6 & 1.3 & 2.4 & 0.4 & 2.2 \\
\hline 3.4 & 3.6 & 1.2 & 2.5 & 1.5 & 5.0 \\
\hline 37.6 & 23.0 & 25.4 & 20.0 & 16.2 & 342.0 \\
\hline 1.5 & 1.2 & 0.8 & 0.9 & 0.4 & 1.9 \\
\hline & & & & & \\
\hline & & & & & \\
\hline & & & & & \\
\hline & & & & & \\
\hline & & & & & \\
\hline 108 & 510 & 128 & 2110 & 204 & 214 \\
\hline 10.1 & 13.7 & 25.5 & 40.1 & 18.7 & 24.4 \\
\hline 0.28 & 1.30 & 0.33 & 5.40 & 0.52 & 0.55 \\
\hline 4.9 & 7.2 & 15.0 & 24.9 & 10.0 & 14.0 \\
\hline 600 & 2860 & 170 & 2420 & 445 & 396 \\
\hline 56.0 & 76.7 & 33.9 & 46.0 & 40.7 & 45.2 \\
\hline 2.99 & 14.27 & 0.85 & 12.08 & 2.22 & 1.98 \\
\hline 52.4 & 79.2 & 38.6 & 55.8 & 42.5 & 50.3 \\
\hline 220 & 230 & 34 & 260 & 144 & 66 \\
\hline 20.5 & 6.2 & 6.8 & 4.9 & 13.2 & 7.5 \\
\hline 1.81 & 1.89 & 0.28 & 2.14 & 1.18 & 0.54 \\
\hline 31.7 & 10.5 & 12.7 & 9.9 & 22.6 & 13.7 \\
\hline 144 & 128 & 170 & 470 & 300 & 200 \\
\hline 13.4 & 3.4 & 33.9 & 8.9 & 27.4 & 22.8 \\
\hline 0.63 & 0.56 & 0.74 & 2.04 & 1.30 & 0.87 \\
\hline 11.0 & 3.1 & 33.6 & 9.4 & 24.9 & 22.1 \\
\hline & & & & & \\
\hline 280 & 435 & 280 & 760 & 305 & 490 \\
\hline o & 9 & 0 & 0 & 0 & 0 \\
\hline 1.7 & 10.4 & 2.0 & 10.5 & 4.6 & 18.8 \\
\hline fine, fibrous & medium & $\begin{array}{l}\text { coarse chunky } \\
\text { pumice }\end{array}$ & sandy, fibrous & sandy & fibrous chunky \\
\hline dk. brown & very $\mathrm{dk}$. brown & dk. black & it. brown & & dk. brown \\
\hline$\# 2192$ & \#2193 & \#2194 & \#2195 & $\# 2196$ & \#2197 \\
\hline
\end{tabular}




\section{Appendix 3 cont.: Results of Soil Analyses for all 29 sample sites}

\begin{tabular}{|c|c|c|c|c|c|c|}
\hline soil sample 18 & soil sample 19 & soil sample 20 & soil sample 21 & soil sample 22 & soil sample 23 & soil sample 24 \\
\hline & & & & & & \\
\hline 109 & 109 & 103 & 90 & 66 & 40 & 75 \\
\hline 5.4 & 5.4 & 6.1 & 5.0 & 6.7 & 7.9 & 7.3 \\
\hline 0.3 & 1.1 & 1.4 & 0.4 & 1.2 & 0.2 & 0.8 \\
\hline 0.77 & 8.33 & 3.22 & 1.09 & 3.61 & 0.78 & 4.10 \\
\hline 0.81 & 1.10 & 5.92 & 1.32 & 3.29 & 0.54 & 2.72 \\
\hline 1.58 & 9.43 & 9.14 & 2.41 & 6.90 & 1.32 & 6.82 \\
\hline 1.17 & 0.91 & 2.09 & 1.52 & 2.26 & 0.96 & 1.13 \\
\hline 0.68 & 0.39 & 2.81 & 0.20 & 2.51 & 0.15 & 0.39 \\
\hline 0.2 & 0.2 & 0.3 & 0.2 & 3.1 & 0.7 & 2.7 \\
\hline 1.7 & 0.9 & 0.7 & 0.5 & 1.3 & 0.6 & 3.2 \\
\hline 1.32 & 0.42 & 0.98 & 1.39 & 1.22 & 1.18 & 0.61 \\
\hline 0.7 & 0.1 & 0.2 & 0.8 & 0.5 & 0.5 & 0.1 \\
\hline 39 & 102 & 195 & 44 & 46 & 6 & 20 \\
\hline 0.24 & 0.22 & 0.22 & 0.13 & 0.22 & 0.22 & 0.22 \\
\hline & & & & & & \\
\hline & & & & & & \\
\hline 43 & 111 & 201 & 40 & 30 & 0 & 15 \\
\hline 6 & 35 & 16 & 6 & 31 & 1 & 20 \\
\hline 306 & 222 & 1090 & 144 & 720 & 344 & 970 \\
\hline & & & & & & \\
\hline 2.4 & 10.8 & 2.2 & 2.4 & 2.7 & 1.0 & 9.0 \\
\hline 12.8 & 2.8 & 6.4 & 12.0 & 4.1 & 1.2 & 7.2 \\
\hline 184.0 & 85.0 & 15.8 & 20.0 & 61.0 & 24.8 & .78 .0 \\
\hline 7.0 & 6.0 & 1.0 & 0.8 & 2.6 & 1.0 & 1.8 \\
\hline & & & & & & \\
\hline & & & & & & \\
\hline & & & & & & \\
\hline & & & & & & \\
\hline & & & & & & \\
\hline 306 & 222 & 1090 & 144 & 720 & 344 & 970 \\
\hline 24.9 & 15.2 & 22.1 & 13.7 & 25.0 & 18.4 & 9.3 \\
\hline 0.78 & 0.57 & 2.79 & 0.37 & 1.84 & 0.88 & 2.48 \\
\hline 13.3 & 8.3 & 10.9 & 6.5 & 13.7 & 10.0 & 4.5 \\
\hline 512 & 1040 & 2390 & 462 & 1540 & 1120 & 7620 \\
\hline 41.7 & 71.0 & 48.4 & 44.1 & 53.5 & 59.8 & 73.0 \\
\hline 2.55 & 5.19 & 11.93 & 2.31 & 7.68 & 5.59 & 38.02 \\
\hline 43.6 & 75.5 & 46.7 & 40.7 & 57.2 & 63.4 & 69.6 \\
\hline 190 & 58 & 1160 & 280 & 310 & 148 & 1580 \\
\hline 15.5 & 4.0 & 23.5 & 26.7 & 10.8 & 7.9 & 15.1 \\
\hline 1.56 & 0.48 & 9.54 & 2.30 & 2.55 & 1.22 & 12.99 \\
\hline 26.7 & 7.0 & 37.3 & 40.5 & 19.0 & 13.8 & 23.8 \\
\hline 220 & 144 & 300 & 162 & 310 & 260 & 270 \\
\hline 17.9 & 9.8 & 6.1 & 15.5 & 10.8 & 13.9 & 2.6 \\
\hline 0.96 & 0.63 & 1.30 & 0.70 & 1.35 & 1.13 & 1.17 \\
\hline 16.4 & 9.2 & 5.1 & 12.3 & 10.1 & 12.8 & 2.1 \\
\hline & & & & & & \\
\hline 1850 & 1650 & 1430 & 1175 & 460 & 1120 & 1645 \\
\hline 0 & 9 & d & 0 & 0 & of & 0 \\
\hline 44.7 & 16.5 & 40.5 & 44.1 & 2.6 & 2.7 & 35.3 \\
\hline medium & medium & & very fine, fibrous & fibrous & chunky & very fine \\
\hline reddish brown & dk. brown & dk. brown/black & dk. brown & gray brown & $\begin{array}{l}\text { med. brown } \\
\text { gray }\end{array}$ & it. gray brown \\
\hline & & I"4ว700 & H+2001 & I+?วก? & แกว? & \\
\hline$\# 2198$ & \#2199 & $\# 2200$ & $\# 2201$ & \#2202 & $\# 2203$ & $\# 2204$ \\
\hline
\end{tabular}




\section{Appendix 3 cont.: Results of Soil Analyses for all 29 sample sites}

\begin{tabular}{|c|c|c|c|c|}
\hline soil sample 25 & soil sample 26 & soil sample 27 & soil sample 28 & soil sample 29 \\
\hline 136 & 152 & 29 & 68 & 66 \\
\hline 7.8 & 7.3 & 7.5 & 5.9 & 5.8 \\
\hline 0.8 & 1.5 & 0.2 & 1.2 & 0.7 \\
\hline 3.43 & 8.48 & 0.89 & 6.64 & 2.83 \\
\hline 2.39 & 3.87 & 0.48 & 3.54 & 2.55 \\
\hline 5.82 & 12.35 & 1.37 & 10.18 & 5.38 \\
\hline 0.96 & 1.74 & 0.50 & 1.61 & 1.35 \\
\hline 0.74 & 1.23 & 0.10 & 0.41 & 0.50 \\
\hline 4.2 & 2.6 & 0.5 & 0.6 & 0.4 \\
\hline 0.6 & 2.5 & 1.9 & 1.3 & 1.6 \\
\hline 0.56 & 0.70 & 0.60 & 0.71 & 0.83 \\
\hline 0.1 & 0.1 & 0.1 & 0.1 & 0.1 \\
\hline 16 & 144 & 2 & 153 & 76 \\
\hline 0.2 & 0.3 & 1 & 0.2 & 0.2 \\
\hline & & & & \\
\hline & & & & \\
\hline 22 & 219 & 1 & 104 & 50 \\
\hline 27 & 11 & 7 & 6 & 8 \\
\hline 860 & 830 & 48 & 180 & 236 \\
\hline & & & & \\
\hline 50.0 & 53.0 & 0.6 & 1.4 & 1.0 \\
\hline 8.4 & 10.7 & 2.0 & 2.7 & 2.2 \\
\hline 78.0 & 103.0 & 43.0 & 60.0 & 57.0 \\
\hline 2.2 & 2.4 & 0.5 & 1.1 & 1.2 \\
\hline & & & & \\
\hline & & & & \\
\hline & & & & \\
\hline & & & & \\
\hline 860 & 830 & 48 & 180 & 236 \\
\hline 6.4 & 5.8 & 12.1 & 5.4 & 10.7 \\
\hline 2.20 & 2.12 & 0.12 & 0.46 & 0.60 \\
\hline 3.1 & 2.8 & 6.7 & 2.7 & 5.2 \\
\hline 10270 & 11420 & 128 & 2470 & 1450 \\
\hline 76.1 & 79.2 & 32.3 & 74.4 & 66.0 \\
\hline 51.25 & 56.99 & 0.64 & 12.33 & 7.24 \\
\hline 71.7 & 75.5 & 35.8 & 71.5 & 63.2 \\
\hline 1990 & 1780 & 20 & 400 & 360 \\
\hline 14.7 & 12.3 & 5.1 & 12.0 & 16.4 \\
\hline 16.37 & 14.64 & 0.16 & 3.29 & 2.96 \\
\hline 22.9 & 19.4 & 8.9 & 19.1 & 25.9 \\
\hline 380 & 390 & 200 & 270 & 150 \\
\hline 2.8 & 2.7 & 50.5 & 8.1 & 6.8 \\
\hline 1.65 & 1.70 & 0.87 & 1.17 & 0.65 \\
\hline 2.3 & 2.3 & 48.6 & 6.8 & 5.7 \\
\hline & & & & \\
\hline 1710 & 2465 & 380 & 945 & 1120 \\
\hline 0 & 9 & 9 & 9 & 0 \\
\hline 59.2 & 60.3 & 0.9 & 13.8 & 12.5 \\
\hline fibrous & fibrous & $\begin{array}{l}\text { very rocky } \\
\text { pumice }\end{array}$ & moist & fibrous \\
\hline very dk. brown & $\begin{array}{l}\text { very dk. black } \\
\text { brown }\end{array}$ & $\begin{array}{l}\text { med. gray } \\
\text { brown }\end{array}$ & $\begin{array}{l}\text { very dk. moist } \\
\text { black }\end{array}$ & med. gray black \\
\hline$\$ 2205$ & $\# 2206$ & $\# 2207$ & $\# 2208$ & $\# 2209$ \\
\hline
\end{tabular}

